JOSÉ NEANDER SILVA ABREU

\title{
MEMÓRIA E TRANSTORNO DO DÉFICIT DE ATENÇÃO E HIPERATIVIDADE
}

Tese apresentada ao Instituto de Psicologia da Universidade de São Paulo, como parte dos requisitos para obtenção do título de Doutor em Psicologia (Neurociências e Comportamento)

São Paulo 
JOSÉ NEANDER SILVA ABREU

\section{MEMÓRIA E TRANSTORNO DO DÉFICIT DE ATENÇÃO E HIPERATIVIDADE}

Tese apresentada ao Instituto de Psicologia da Universidade de São Paulo, como parte dos requisitos para obtenção do título de Doutor em Psicologia

Área de concentração: neurociências e comportamento

Orientador: Prof. Dr José Lino Oliveira Bueno Co-orientador: Prof Dr. Gilberto Fernando Xavier

São Paulo 


\section{AUTORIZO A REPRODUÇÃO E DIVULGAÇÃO TOTAL OU PARCIAL DESTE TRABALHO, POR QUALQUER MEIO CONVENCIONAL OU ELETRÔNICO, PARA FINS DE ESTUDO E PESQUISA, DESDE QUE CITADA A FONTE.}

Catalogação na publicação

Serviço de Biblioteca e Documentação

Instituto de Psicologia da Universidade de São Paulo

Abreu, José Neander Silva.

Memória e transtorno do déficit de atenção e hiperatividade / José Neander Silva Abreu; orientador José Lino Oliveira Bueno; coorientador Gilberto Fernando Xavier. -- São Paulo, 2007.

134 p.+ Apêndices + Anexos.

Tese (Doutorado - Programa de Pós-Graduação em Psicologia. Área de Concentração: Neurociências e Comportamento) - Instituto de Psicologia da Universidade de São Paulo.

1. Memória 2. Transtorno da falta de atenção com hiperatividade

3. Atenção 4. Neuropsicologia I. Título.

BF371 


\title{
APROVAÇÃO COMITÊ DE ÉTICA EM PESQUISA
}

IPUSP

\author{
Aprovação \\ Of. 1406/CEPH-04/07/06
}




\section{DEDICATÓRIA}

Aos meus pais, Wesley e Wilma, que me ensinaram dedicação, respeito e integralidade no passado e no presente.

À Julia, que me ensina a compreender que o tempo não para.

À Cláudia, que fez parte da história. A história continua se renovando sempre.

Aos pacientes com TDAH e suas famílias: esperanças de novas histórias. 


\section{AGRADECIMENTOS}

Ao professor José Lino Oliveira Bueno pela orientação na elaboração e execução deste trabalho.

Ao professor Gilberto Fernando Xavier, co-orientador, pelas sugestões teóricas e de análise do presente estudo.

À professora Nayara Silva Argollo Vieira, Rita Lucena e Marielza Veiga pela indicação dos participantes da pesquisa e sugestões de leitura.

A vocês, muito obrigado pela oportunidade e contribuições para aqui chegar.

Ao Lino e à Belmira, amigos, que me receberam e acolheram em tantos momentos desde o mestrado. Obrigado pelo quarto de estudo e amigos em Ribeirão, pelos papos e pela para amizades.

Ao Gilberto e à Silvia, receptivos em São Paulo, conversando sobre as idas e vindas de Salvador.

À direção do Centro de Ciências da Saúde da Universidade Federal do Recôncavo da Bahia: Francisco, Thiago e Luis, obrigado!

Aos companheiros de caminhada antigos e novos do laboratório de Processos Associativos, Controle Temporal e Memória: Taíza, Lela, Patrícia, Mariana, Rita, Danilo, Raquel, Érico, Chico, Lézio e o João, sempre disponível. Gente, muito obrigado pelo apoio de vocês.

Não dá para esquecer daqueles que estão no laboratório de Fisiologia e Comportamento (SP): André, João, Arnaldo, Andréa, Rodrigo, Tatiana, Claudia e a Cláudia Berlim. Amiga, companheira de papo e de bar. E ao Renato e Rafael. Minha vida temporária em São Paulo não seria a mesma sem vocês três. E tem a Bete, irmã, cheia de energia, estimulando no desânimo. Valeu!

Em Salvador, à Fernanda, Ana Louize, Nariana e Samantha. Obrigada pela força na coleta e na amizade de vocês.

Aos meus amigos da capital soteropolitana. Moisés e Érica, Moisés Domingues e a Cris, Sérgio (Galo) e Anália,Serginho e Ana Carla; Pimenta, companheiro de vela; Moisés Andrade e Solange; o Paulo Sérgio, doutor e amigo; ao Eduardo, muito grato 
pelas contribuições mesmo no meio do jogo do Brasil; Naninha, amiga e suporte nas horas mais difíceis.

À Nina, Rodrigo, Eduardo, Ana, amigos que chegaram por tabela. Crianças nos ensinam sempre! À Eny, que vai fazer sempre eternamente seu lugar! À Vivian,pela reconstrução de relações! À Laura e Bob, lançando sempre a gente à frente!

À Noemi, Ester, Junior e Sheila, companheiros de vida,que mesmo à distância me estimulam sempre, me acompanham, me dão suporte. O lugar é especial!

À Eliã, Caio e Cauã pelo recente apoio e ao Raimundo, amigo próximo dos que a gente se orgulha de ter.

E ao Amauri, companheiro de caminhada e profissão,apoio constante, mão que suporta!

Obrigado a vocês todos e nesta reta final, vocês sabem o quanto!

Neander, em 06 de agosto de 2007. 


\section{RESUMO}

ABREU, José Neander Silva. Memória e Transtorno do Déficit de Atenção e Hiperatividade. 2007. 134p.+ Apêndices + Anexos. Tese (Doutorado). Instituto de Psicologia, Universidade de São Paulo, São Paulo, 2007.

O Transtorno do Déficit de Atenção/Hiperatividade (TDAH) é o transtorno psiquiátrico mais comum em crianças e adolescentes, com prevalência de 6\%. O TDAH classificase nos subtipos desatento (TDAHD), hiperativo (TDAHH) ou combinado (TDAHC). Suas manifestações incluem problemas de cognição, comportamentais, afetivos e sociais. Distúrbios de memória e atenção são problemas cognitivos freqüentes. A memória de curta e longa duração foi avaliada em 44 sujeitos portadores do TDAH por subtipos, (TDAHD, n=17; TDAHH, n=11;TDHAC, n=16; idade:12,8 anos; escolaridade: 6,1 a) e 43 indivíduos não portadores que constituíram o grupo controle (idade: 12,11 anos; escolaridade: 6,4 a). Os escores foram a média de evocações corretas em um experimento desenvolvido para este estudo. 64 figuras distribuídas em 4 apresentações com 16 figuras cada constituíram a avaliação de memória (MEMO). As apresentações para recordação imediata e tardia: memória categorizável agrupada, memória nãocategorizável seriada, memória não-categorizável agrupada. Inteligência e atenção também foram analisadas. Os resultados mostraram os grupo TDAHH e TDAHC tiveram um pior desempenho na memória de longa duração categorizável e não categorizável na apresentação seriada; os três grupos com TDAH tiveram desempenho inferior ao grupo controle com figuras categorizáveis e não-categorizáveis agrupadas, com maior efeito para TDAHD e TDAHC. Os resultados indicam prejuízo de memória de longa e curta duração no TDAH independente da contribuição de estratégias de memória.

Palavras-Chave: Memória, Transtorno do déficit de atenção e hiperatividade, Atenção, Neuropsicologia. 


\begin{abstract}
ABREU, José Neander Silva. Memory and Attention Deficit/Hyperactivity Disorder. São Paulo, 2007. 134p.+ Appendices . Thesys (level: Doctoral). Instituto de Psicologia, Universidade de São Paulo, São Paulo, 2007.

Attention Deficit Hyperactivity Disorder (ADHD) is the most common psychiatric disorder among children and teenagers, with a prevalence of $6 \%$. ADHD disorder has three subtypes: inattentive (ADHDI), hyperactive (ADHDH) and combined (ADHDC). The symptoms include cognitive, behavioral, affective, and social disturbances. Memory and attention deficits are the cognitive problems that frequently attend this disorder. Long and short-term memory were assessed in 44 children and teenagers with ADHD (ADHDD, n=17; ADADH, n=11;ADHDC, $n=16$; age: 12,8 y; 6,1 years of education) and 44 healthy participants (Control group, age: 12,11; 6,4 years of education). An experiment was developed to investigate memory (MEMO). The experiment consisted of 64 figures in 4 different presentations. Each presentation had 16 figures designed to measure immediate and delayed recall in four conditions: serial categorizable memory, grouped categorizable memory, serial non-categorizable memory, and grouped noncategorizable memory. Intelligence and attention were also assessed. The recall of ADHDD and ADHDC groups was worse in the categorizable and non-categorizable serial conditions; the performance of all three ADHD groups was worse than that of the control group with respect to the two grouped conditions, but ADHDD and ADHDC were the worst. These results suggest memory deficit for long and short-term memory on ADHD independent of memory strategies contribution.
\end{abstract}

Keywords: Memory, Attention-deficity/hyperactivity disorder, Attention, Neuropsychology. 


\section{LISTA DE FIGURAS}

Figura 1. Modelo de Relação Funcional da Atenção (BARKLEY, 1996) 35

Figura 2. Exemplos de figuras da apresentação categorial seriada.

$\begin{array}{ll}\text { Figura 3. Matriz da apresentação categorial agrupada. } & 74\end{array}$

$\begin{array}{ll}\text { Figura 4. Exemplos de figuras da apresentação não-categorial seriada. } & 74\end{array}$

Figura 5. Matriz da apresentação não-categorial agrupada. 75

Figura 6. Comparação do Desempenho dos Grupos TDAHD, TDAHH e 89 TDAHC e Controle na Memória de Longa Duração Seriada (MLDS).

Figura 7. Comparação do Desempenho dos Grupos TDAHD, TDAHH e 90 TDAHC e Controle na Memória de Longa Duração Agrupada (MLDA).

Figura 8. Índice de Desempenho para Comparação entre a Diferença dos Escores de Memória Seriada - MS.

Figura 9. Índice de Desempenho para Comparação entre a Diferença dos Escores de Memória Agrupada - MA. Média e erro padrão.

Figura 10. Índice de Desempenho para Comparação entre a Diferença dos 94

Escores de Memória de Longa Duração Agrupada (MLDA) e Seriada (MLDS) Categorial (MLDCA/MCDCS) e Não Categorial (MLDCNCA/MLDNCS).

Figura 11. Índice de Desempenho para Comparação entre a Diferença dos

Escores de Memória de Curta Duração Agrupada (MCDA) e Seriada (MCDS) Categorial (MCDCA/MCDCS) e Não Categorial (MCDNCA/MCDNCS).

Figura 12.Aprendizagem Seriada Categorial. Média e erro padrão. T1, T2 e 97 T3 são tentativas da aprendizagem seriada.

Figura 13. Aprendizagem Seriada Não Categorial.

Figura 14. Aprendizagem Agrupada Categorial (APAC) e Aprendizagem 99 Seriada Categorial (APSC).

Figura 15. Aprendizagem Agrupada Categorial (APAC) e Aprendizagem 99 
Agrupada Não Categorial (APANC).

Figura 16. Índice de Aprendizagem Categorial (IAC) e Não Categorial (IANC). 100 Figura 17. Quoeficientes de Inteligência Bateria WISC III. Médias dos QIs e 101 erro padrão.

Figura 18. Índices Fatoriais da Bateria WISC III. Média dos índices e erro 103 padrão. ICV: índice de compreensão verbal.

Figura 19. Tempo de Reação (TR) nas provas da Bateria TAVIS-3.. 104

Figura 20. Erros por Omissão. 105

$\begin{array}{ll}\text { Figura 21. Erros por Ação } & 106\end{array}$ 


\section{LISTA DE ABREVIATURAS}

CPT Continuous performance task

DSMIV Diagnostic and Statistical Manual of Mental Disorders $4^{\text {th }}$ ed.

EA Erros por ação

EO Erros por omissão

FE Funções executivas

ICV Índice de compreensão verbal

IOP Índice de organização perceptual

IRD Índice de resistência à distração.

IVP Índice de velocidade de processamento

MCDA Memória de Curta Duração Agrupada

MCDS Memória de Curta Duração Seriada

MLDA Memória de Longa Duração Agrupada

MLDS Memória de Longa Duração Seriada

SNAP-IV Swanson, Nolan and Pelham Questionnaire

TAVIS-III Teste de atenção visual - 3a versão.

TD Transtorno de Conduta

TDA Transtorno do Déficit de Atencão

TDAH Transtorno do Déficit de Atencão e Hiperatividade

TDAHC Transtorno do Déficit de Atenção e Hiperatividade do tipo combinado

TDAHD Transtorno do Déficit de Atenção e Hiperatividade de predomínio desatento

TDAHH Transtorno do Déficit de Atenção e Hiperatividade de predomínio hiperativo

TDO Transtorno Desafiante Opositor

TR Tempo de reação 
WISC III Wescheler Intelligence Scale for Children - versão III 


\section{SUMÁRIO}

1. INTRODUÇÃO

1. 1. O Transtorno do Déficit de Atenção e Hiperatividade (TDAH)

1.2. Processos de atenção e suas disfunções relacionadas ao TDAH

1.3. Memória e suas disfunções relacionadas ao TDAH

2. OBJETIVOS

3. MÉTODOS

3.1 Caracterização Situacional

3.2 Descrição da Amostra

3.2.1.Grupo Caso: Portadores do Transtorno do Déficit de Atenção/Hiperatividade

3.2.2. Grupo Controle 73

3.3. Instrumentos e Procedimentos $\quad 73$

3.3.1. MEMO: Avaliação de Memória $\quad 74$

3.3.1.1. Categorial Seriada

3.3.1.2. Categorial Agrupada

3.3.1.3. Não Categorial Seriada

3.3.1.4. Não Categorial Agrupada 77

3.3.2. WISC III: Avaliação de Inteligência 79

3.3.3. TAVIS 3: Avaliação de Atenção 80

3.3.3.1. Atenção Seletiva

3.3.3.2. Atenção Dividida 81

3.3.3.3. Atenção Sustentada 82

3.3.4. Visão de Cores 82

3.4. Desenho Experimental e Análise Estatística 83

4. RESULTADOS 84

4.1. Características SócioDemográficas e de Diagnóstico de acordo com os Grupos

4.1.1. Características SócioDemográficas

4.1.2. Diagnóstico - Escala SNAPIV 86

4.1.3. Diagnóstico - Escala de TDAH - Versão para Professores $\quad 87$

4.2. Avaliação de Memória $\quad 89$

4.2.1. Memória de Longa Duração Seriada (MLDS)

4.2.2. Memória de Longa Duração Agrupada (MLDA) 
4.2.3. Comparação das Médias dos Escores da Memória de Longa Duração Seriada (MLDS) e da $3^{a}$ Tentativa da Apresentação Seriada - Memória de Curta Duração Seriada (MCDS)90

4.2.4. Comparação das Médias dos Escores da Memória Agrupada (MA) entre Memória de Longa Duração Agrupada (MLDA) e da Apresentação Agrupada - Memória de Curta Duração Agrupada (MCDA).

4.2.5. Memória de Longa Duração Categorial Seriada (MLDCS) e Agrupada (MLDCA)

4.2.6. Aprendizagem Agrupada (APA) e Aprendizagem Seriada 95 (APSTentativa 1)

4.2.7. Aprendizagem Seriada (APS) Categorial e Não Categorial 96

4.2.8. Aprendizagem Seriada (APS) e Aprendizagem Agrupada 99 (APA)

4.2.9. Aprendizagem Agrupada Categorial (APAC) e Não Categorial 99 (APANC)

4.2.10. Índice de Aprendizagem Categorial e Não Categorial 101

4.3. Avaliação de Inteligência 102

4.3.1. Quoeficientes de Inteligência (QI) 102

4.3.2. Índices Fatoriais 103

4.4. Avaliação de Atenção 104

4.4.1.Tempo de Reação

4.4.2. Erros por Omissão (EO) 106

$\begin{array}{ll}\text { 4.4.3. Erros por ação (EA) } & 107\end{array}$

$\begin{array}{ll}\text { 5. DISCUSSÃO } & 108\end{array}$

6. CONCLUSÕES 118

$\begin{array}{lr}\text { 7. REFERÊNCIAS BIBLIOGRÁFICAS } & 120\end{array}$

$\begin{array}{ll}\text { APÊNDICES } & 135\end{array}$

$\begin{array}{ll}\text { A - Termo de Consentimento Livre e Esclarecido } & \\ \text { B - Questionário Estruturado } & 136\end{array}$

$\begin{array}{ll}\text { C - Folha de Registro -Piloto } & 138\end{array}$

D - Folha de Registro - MEMO 139

$\begin{array}{ll}\text { ANEXOS } & 141\end{array}$

A - Aprovação do Comitê de Ética em Pesquisa com Seres Humanos IPUSP

$B$ - Escala SNAP-IV 


\section{INTRODUÇÃO}

\subsection{O Transtorno do Déficit de Atenção e Hiperatividade(TDAH)}

$\mathrm{Na}$ história da medicina, doenças e distúrbios do funcionamento da saúde mental em adultos e crianças têm sido descritos como tendo origem biológica, com efeitos comportamentais. Assim, espera-se que o diagnóstico de um transtorno, que é conhecido pela falta ou redução de atenção e por agitação e etiologia biológica receba um enfoque especial.

O transtorno do déficit de atenção e hiperatividade (TDAH) não só é conhecido por ser um dos distúrbios neuropsiquiátricos mais comuns na infância e adolescência (MATTOS, 2001), mas, também porque engloba sintomas que são comuns em portadores e não portadores, tais como: dificuldade de concentração, falha na finalização de tarefas ou inconsistência na realização de um objetivo definido (BARKLEY, 2002).

O TDAH consiste em um padrão persistente de desatenção e/ou hiperatividadeimpulsividade, mais freqüente e grave do que aquele observado em indivíduos em nível equivalente de desenvolvimento (AMERICAN PSYCHIATRIC ASSOCIATION, 1994). Seus portadores apresentam dificuldades relacionadas ao desempenho e adaptação, que são interpretadas como indicadores de um nível de desenvolvimento inferior ao esperado para a idade. Pais de crianças e adolescentes com TDAH sofrem freqüentemente com dificuldades relacionadas ao nível de amadurecimento psicológico, tanto quanto com o desenvolvimento acadêmico deficitário.

Foram caracterizados três eixos de desempenho abaixo do esperado para o desenvolvimento normal, acadêmico, cognitivo e comportamental, que contribuem conjuntamente para problemas inerentes, e prejudicam o funcionamento acadêmico, social e familiar do portador. Além disso, existem evidências crescentes de que o TDAH, comum durante a idade escolar, se estenda à vida adulta (ROHDE e colaboradores, 1999; ROHDE e HALPERN, 2004), permanecendo com a manifestação de sintomas entre 60 a $70 \%$ dos casos após a adolescência (BARKLEY e colaboradores, 2002a). 
A primeira descrição do TDAH, realizada por um médico, Still (1902), tratou de uma condição de anormalidade física por um caso de hipercinesia em criança. Ao longo do século $X X$, várias nomenclaturas para o transtorno foram utilizadas no meio médico e laico. Na década de 40, a denominação "lesão cerebral mínima" definiu o transtorno até 1962, quando a terminologia "disfunção cerebral mínima" tornou-se uma referência mais coerente com as alterações das vias nervosas, do que propriamente a presença de uma lesão estrutural, sendo compatível com a presença dos sintomas sem evidências de lesão cerebral (ROHDE e colaboradores, 2000; ROHDE e HALPERN, 2004). Ainda na década de 60, o Diagnostic and Statistical Manual of Mental Disorders, em sua segunda edição inseriu o termo "reação hipercinética" para caracterizar o transtorno.

A partir dos anos 70 a Classificação Internacional de Doenças, na versão 9 (CID9) (ORGANIZAÇÃO MUNDIAL DA SAÚDE, 1978) incluiu a nomenclatura "Síndrome Hipercinética". A partir dos anos 80 , a publicação do DSM-III trouxe a cunhagem do termo "Distúrbio do Déficit de Atenção" com ou sem "hiperatividade". As diferenças fundamentais em relação às classificações anteriores foram estabelecidas sobre os seguintes argumentos: a) o abandono da tentativa de incluir a etiologia na definição e terminologia diagnóstica; b) consenso, na época, de que a hiperatividade, apesar de mais facilmente identificada, não era o problema mais importante (ROHDE e colaboradores, 1998).

A característica "desatenção" passou a receber um maior enfoque como sintoma da tríade que compõe a síndrome. A "impulsividade", um importante sintoma conhecido hoje no TDAH, tornou-se importante para os pesquisadores e clínicos, tanto quanto a "hiperatividade". Na revisão do DSM-III o termo para o transtorno voltou a enfatizar a hiperatividade, passando a ser denominado "Distúrbio de Hiperatividade com Déficit de Atenção".

As pesquisas que subsidiaram o DSM-III-R (revisado) e o DSM-IV (AMERICAN PSYCHIATRIC ASSOCIATION, 1987, 1994) equilibraram a relação entre os sintomas sobre a vida dos indivíduos, adotando atualmente a terminologia "Transtorno do Déficit de Atenção/Hiperatividade". O termo hiperatividade, de acordo com Mattos e 
colaboradoress (2006a) foi descrito "metamorfoseado do grego hipercinese, e corresponde ao termo latino superatividade (o termo correto)".

Em geral, indivíduos portadores de TDAH são mais conhecidos pela presença de sintomas relacionados à agitação motora (hiperatividade), e menos, pelos componentes de desatenção e impulsividade. Quando presentes, desatenção e hiperatividade são sintomas erroneamente identificados como características de personalidade e não como característicos do transtorno. Os sintomas do TDAH podem levar a prejuízo na aquisição de conhecimento, com implicações sobre o desempenho acadêmico e laborativo.

A prevalência do TDAH é bastante significativa na população em idade escolar. As taxas de prevalência encontram-se entre 3,0-6,0 \%, dentre a população na faixa etária de infância e adolescência (ROHDE e colaboradores, 1998; ROHDE e HALPERN, 2004), quando adotados os critérios plenos do DSM-IV. Os estudos norteamericanos melhor controlados sugerem taxas variando entre 2,5-8,0 \%, dependendo do tipo de TDAH. Estas diferenças são decorrentes prioritariamente das questões metodológicas quanto ao tipo de amostra, delineamento, fonte de informação, idade ou como os critérios do DSM-IV, do que à prevalência na população (FARAONE e colaboradores, 2003; GOLFETO e BARBOSA, 2003). Pesquisas que utilizam os critérios do DSM-IV concordam nas taxas de prevalência (ROHDE e HALPERN, 2004).

Guardiola (1994), em Porto Alegre-RS, avaliou 484 crianças da $1^{\text {a }}$ série do ensino fundamental, obtendo duas taxas de prevalência: a) 18,0\%, adotados os critérios adotados do DSM-III-R; b) 3,5\%, utilizando fatores mais globais, incluindo avaliações comportamentais, psicométrica e exame neurológico evolutivo.

Rohde e colaboradores (1999a, 1999b, 2000b), em Porto Alegre-RS, investigando 1013 adolescentes entre 12 e 14 anos de idade, constataram uma prevalência de $5,8 \%$, sendo adotados 18 critérios do DSM-IV para TDAH e avaliação psiquiátrica no caso dos adolescentes que tiveram triagem positiva para TDAH.

Souza e colaboradores (2001) descreveram uma prevalência do TDAH em diferentes países, incluindo o Brasil, em torno de 5,0 a 8,0\%. Barbosa (1995), em João Pessoa-PB, constatou uma prevalência de $3,3 \%$, com o uso da escala de Conners. Pelo exposto ratificou-se que a variação decorre tanto da metodologia utilizada quanto dos 
instrumentos específicos, como critérios do DSM-IV ou a opção por incluir avaliação neuropsicológica ou neuroevolutiva para o diagnóstico (GUARDIOLA e colaboradores, 2000).

Vasconcelos e colaboradores (2003), numa escola de ensino fundamental em Niterói-RJ, avaliaram 403 estudantes TDAH positivos, encontrando uma prevalência de $17,8 \%$. Em sendo superior às prevalências encontradas, pode-se justificar a diferença na prevalência em decorrência de: a) amostra reduzida para estudo epidemiológico; b) dados obtidos na classe econômica populacional menos favorecida; c) uso de critérios diagnósticos fundamentados sobre relato dos professores a partir dos critérios do DSMIV. Outros dois fatores foram considerados: o primeiro, referido pelos autores, trata de uma baixa validade externa para diferentes classes socioeconômicas; o segundo, é que crianças de classes menos favorecidas tendem a ser avaliadas por seus pares e professores como mais problemáticas (CARVALHO, 2004).

Carvalho (2004) verificou que alunos provenientes de famílias com renda de até cinco salários-mínimos representavam $22,0 \%$ do total de estudantes da escola e $36 \%$ dos sujeitos encaminhados para reforço escolar. Ainda, constatou que os meninos, de classe economicamente menos favorecida, compunham o maior percentual $(65,7$ e $71,0 \%)$ dos alunos encaminhados para reforço e relacionados com problemas de disciplina (comportamentais), respectivamente. Vasconcelos e colaboradores (2003) constataram que $65,5 \%$ dos meninos, com queixas sobre si, respondidas por professores de escola pública por meio de questionários, eram provenientes de famílias com até cinco salários-mínimos.

A proporção do TDAH em meninos e meninas varia em estudos populacionais (2:1) e clínicos (9:1), sendo justificada pelo fato de meninas apresentarem mais desatenção e menos transtornos de conduta e comorbidades. Este fato parece diminuir sensivelmente a percepção de incômodo nas escolas e famílias, resultando provavelmente em menos queixas e menor encaminhamento para tratamento (ROHDE e colaboradores, 2004; WOLRAICH e colaboradores, 1996).

O TDAH divide-se em três tipos ou subtipos, quais sejam: a) TDAH com predomínio de desatenção; b) TDAH com predomínio de hiperatividade/impulsividade e; c) TDAH combinado (AMERICAN PSYCHIATRIC ASSOCIATION, 1994). Biederman e 
colaboradores (1999) e Cantwell (1996) identificaram uma prevalência de 10,0 a 25,0\% dos casos de TDAH em meninas, mas constatando baixa comorbidade com transtorno de conduta e idade de diagnóstico mais avançada em relação aos meninos. No sexo feminino, a prevalência dos subtipos é maior para o combinado (59\%) sendo que o subtipo hiperativo representa apenas $7 \%$ dos casos. Diferenças entre grupos étnicos são menos conhecidas. A impressão clínica apresenta uma maior freqüência do transtorno em classes economicamente menos favorecidas (GUARDIOLA, 1994). Scahill e colaboradores (1999) identificaram fortes associações psicossociais com o TDAH, após realizarem pareamento com a idade e sexo, incluindo baixa renda familiar e residência em lugares populosos.

Os problemas comportamentais centrais que fazem parte da tríade clássica de sintomas do TDAH são: desatenção, impulsividade e hiperatividade (TEICHER e colaboradores, 1996; KUNTSI e STEVENSON, 2000; ROHDE e HALPERN, 2004). Há uma série de problemas que podem simular o TDAH, esses sintomas clássicos do transtorno podem ser apresentados em outras alterações, como na depressão. Os comportamentos podem ser interpretados isoladamente, como resultantes de problemas na relação da criança com amigos ou pais e não menos importante, com sistemas educacionais inadequados.

O TDAH não deve ser interpretado como um conjunto de comportamentos reativos a situações sociais. King e colaboradores (1998) sugeriram que indivíduos portadores de TDAH apresentam, na forma desenvolvimental mais persistente do transtorno, respostas deficitárias ao estresse. As crianças com TDAH apresentam mais problemas relacionados ao desempenho acadêmico e dificuldades comportamentais na escola, mesmo em idade pré-escolar. Esses comportamentos estendem-se para outros ambientes como a própria casa (BARKLEY e colaboradores, 2002c). Os fatores psicossociais não são considerados causas do TDAH. Geralmente, as alterações de conduta são resultantes de transtornos associados. As informações escolares são parte da história do desenvolvimento do indivíduo portador, não constituindo única fonte de informação (ROHDE e colaboradores, 1999b), e devem aditivamente, ser acompanhadas do histórico médico, social e familiar. 
Os três componentes do TDAH têm manifestam-se diferentemente em diferentes ambientes. A desatenção leva a baixa concentração e dificuldades como permanecer em uma mesma tarefa por tempo prolongado. Além disso, as crianças são freqüentemente distraídas por estímulos alheios à tarefa (MATTOS, 2001). Em relação à impulsividade, problemas nas relações com os colegas de sala, suscetibilidade a acidentes e interferências sobre o ritmo da aula são freqüentemente observados por professores e relatados por pais em ambientes clínicos, assim como uma tendência a responder rapidamente perguntas, antes mesmo de serem concluídas (ROHDE e colaboradores, 1999).

A hiperatividade é observada através de sintomas como a fala excessiva e a inquietude motora, o que geralmente se caracteriza por frustração no controle do comportamento por parte dos pais e baixa tolerância no ambiente escolar. As três dimensões dos sintomas do TDAH envolvem no diagnóstico, pelo menos 6 entre 9 critérios para desatenção e/ou hiperatividade, bem como está associada a outros critérios gerais sobre o transtorno (Tabela 1): alguns sintomas presentes antes dos sete anos de idade. Há de se destacar que a presença de sintomas antes dos sete anos de idade não é critério com evidências científicas, mas uma opinião clínica de comitê de especialistas em TDAH (ROHDE e colaboradores, 2000b); prejuízos presentes em mais de um ambiente. O portador do TDAH não apresenta sintomas apenas na escola. A presença dos sintomas do transtorno deve ser observada pelo menos na escola e em casa; prejuízos clinicamente significativos nas esferas social, educacional ou ocupacional; e os sintomas do transtorno (desatenção, hiperatividade e impulsividade) não são resultantes de outros transtornos como transtorno invasivo do desenvolvimento ou depressão. Sintomas depressivos podem incluir redução na concentração, mas não podem ser classificados como TDAH. Outros transtornos psiquiátricos podem evoluir com sintomas de desatenção ou hiperatividade. Entretanto, não devem ser diagnosticados como TDAH (ROHDE \& HALPERN, 2004; SEIDMAN e colaboradores, 1997).

No tipo desatento observa-se a presença de pelo menos seis sintomas do critério A (Tabela 1) com prejuízo escolar geralmente mais significativo (ROHDE e HALPERN, 2004) e a presença dos critérios B a E. A presença de pelo menos seis sintomas do 
critério A para hiperatividade caracterizam, juntamente com os demais critérios ( $B$ a $E$ ) o tipo de predomínio hiperativo/impulsivo. O portador do TDAH do tipo hiperativo/impulsivo apresenta mais freqüentemente comportamentos desviantes, com alta taxa de impopularidade e rejeição pelos colegas. O terceiro tipo é o TDAH combinado onde se observam pelo menos seis sintomas presentes de cada lista, ou seja, para desatenção e para hiperatividade/impulsividade. O portador do TDAH combinado tem um maior prejuízo no funcionamento global quando comparado aos outros dois grupos (ROHDE e colaboradores, 2000a), resultando em combinação de problemas acadêmicos e comportamentais.

Tabela 1 - Critérios Diagnósticos para Transtorno de Déficit de Atenção/Hiperatividade

A. Ou (1) ou (2).

1) Seis (ou mais) dos seguintes sintomas de desatenção persistiram por pelo menos 6 meses, em grau mal-adaptativo e inconsistente com o nível de desenvolvimento:

Desatenção:(a) freqüentemente deixa de prestar atenção a detalhes ou comete erros por descuido em atividades escolares, de trabalho ou outras;

(b) com freqüência tem dificuldades para manter a atenção em tarefas ou atividades lúdicas;

(c) com freqüência parece não escutar quando Ihe dirigem a palavra;

(d) com freqüência não segue instruções e não termina seus deveres escolares, tarefas domésticas ou deveres profissionais (não devido a comportamento de oposição ou incapacidade de compreender instruções)(e) com freqüência tem dificuldade para organizar tarefas e atividades;

(f) com freqüência evita, antipatiza ou reluta a envolver-se em tarefas que exijam esforço mental constante (como tarefas escolares ou deveres de casa);

(g) com freqüência perde coisas necessárias para tarefas ou atividades (por ex., brinquedos, tarefas escolares, lápis, livros ou outros materiais);

(h) é facilmente distraído por estímulos alheios à tarefa;

(i) com freqüência apresenta esquecimento em atividades diárias. 
Tabela 1 - Critérios Diagnósticos para Transtorno de Déficit de Atenção/Hiperatividade Continuação

(2) Seis (ou mais) dos seguintes sintomas de hiperatividade persistiram por pelo menos 6 meses, em grau mal-adaptativo e inconsistente com o nível de desenvolvimento. Hiperatividade:

(a) freqüentemente agita as mãos ou os pés ou se remexe na cadeira;

(b) freqüentemente abandona sua cadeira em sala de aula ou outras situações nas quais se espera que permaneça sentado;

(c) freqüentemente corre ou escala em demasia, em situações nas quais isto é inapropriado (em adolescentes e adultos, pode estar limitado a sensações subjetivas de inquietação);

(d) com freqüência tem dificuldade para brincar ou se envolver silenciosamente em atividades de lazer;

(e) está freqüentemente "a mil" ou muitas vezes age como se estivesse "a todo vapor";

(f) freqüentemente fala em demasia Impulsividade;

(g) freqüentemente dá respostas precipitadas antes de as perguntas terem sido completadas;

(h) com freqüência tem dificuldade para aguardar sua vez;

(i) freqüentemente interrompe ou se mete em assuntos de outros (por ex., intromete-se em conversas ou brincadeiras).

B. Alguns sintomas de hiperatividade-impulsividade ou desatenção que causaram prejuízo estavam presentes antes dos 7 anos de idade.

C. Algum prejuízo causado pelos sintomas está presente em dois ou mais contextos (por ex., na escola [ou trabalho] e em casa).

D. Deve haver claras evidências de prejuízo clinicamente significativo no funcionamento social, acadêmico ou ocupacional.

E. Os sintomas não ocorrem exclusivamente durante o curso de um Transtorno Invasivo do Desenvolvimento, Esquizofrenia ou outro Transtorno Psicótico e não são melhor explicados por outro transtorno mental (por ex., Transtorno do Humor, Transtorno de Ansiedade, Transtorno Dissociativo ou um Transtorno da Personalidade).

FONTE: Adaptada de American Psychiatric Association, 1994 
Um outro fator relevante é que a apresentação clínica varia de acordo com o estágio do desenvolvimento, desde a sintomatologia observada do pré-escolar ao adolescente. Biederman e Faraone (2000) demonstraram numa amostra com 140 meninos, que a idade está associada, significativamente, com o declínio nos sintomas totais do TDAH. Isto é, observa-se uma redução ou remissão da síndrome, e dos sintomas; contudo, observa-se uma menor remissão funcional. A prevalência da remissão de desatenção foi menor que a escala da remissão dos sintomas de hiperatividade e impulsividade, resultando numa menor prevalência de indivíduos do subtipo hiperativo na adolescência e idade adulta. Em indivíduos adultos, os sintomas de agitação motora (hiperatividade) freqüentemente evoluem para sensação de inquietude. Mesmo com essas diferenças comportamentais, o uso de critérios bem definidos pode resultar em um diagnóstico confiável de TDAH nesta faixa etária (MATTOS e colaboradores, 2006a).

As implicações para o desenvolvimento do indivíduo portador parecem ser relevantes em todas as fases da vida. O TDAH está envolvido com risco de baixo desempenho escolar, repetências, expulsões e exclusão, suspensões escolares, relações difíceis com familiares e colegas, desenvolvimento de ansiedade, depressão, baixa auto-estima, problemas de conduta, acidentes de carro e multas por alta velocidade, experimentação e abuso de drogas, e mais freqüentemente na vida adulta problemas no trabalho e no casamento. Alguns destes comportamentos podem estar relacionados às comorbidades, principalmente do Transtorno de Conduta e não somente em função do indivíduo ser ou não portador do TDAH per se (MACDONALD e ACHENBACH, 1996). Entretanto, os sintomas do TDAH não constituem uma expressão do quadro clínico de outros transtornos, embora possas se apresentar como uma comorbidade (BIEDERMAN e colaboradores, 1992). Esta discussão é mais controversa no que tange ao abuso de drogas na adolescência. Trinta a cinqüenta por cento dos indivíduos com TDAH que são adictos apresentam transtorno de conduta. Ainda não há consenso sobre se incidência de TDAH é fator preditivo do abuso de drogas ou se essa correlação depende dos fatores de comorbidade (ROHDE e colaboradores, 2000a).

A etiologia do TDAH parece ser complexa e vem sendo associada mais fortemente tanto a fatores genéticos quanto ambientais. Pesquisas têm apontado para 
causas a partir da vulnerabilidade e interação ambiental, com o envolvimento de vários genes de pequeno efeito (ROHDE e colaboradores, 2004). Estudos com famílias de portadores revelaram que os pais têm 2 a 8 vezes mais possibilidades em apresentar 0 transtorno, com evidências de apresentação familiar (BIEDERMAN e colaboradores, 1992; FARAONE e colaboradores, 1996). Essas evidências não excluem a possibilidade de que a transmissão familial tenha origem ambiental. Para responder a este tipo de questão, pesquisas como a de Taphar e colaboradores (1999) realizadas com gêmeos, verificaram o grau de herdabilidade no TDAH, é estimado em 0,70.

A herdabilidade é importante para estimar em que grau o fenótipo de uma doença pode ser influenciado por fatores genéticos. Encontrou-se uma freqüência de prevalência do TDAH três vezes maior entre filhos de pais biológicos do que em crianças adotadas (SPRICH e colaboradores, 2000). Esses resultados corroboram a hipótese etiológica genética para o transtorno. Na clínica, é comum observar pais identificando-se com os sintomas dos filhos portadores do transtorno, tanto na esfera acadêmica quanto comportamental, o que justifica em muitos casos o atraso no processo para encaminhamento para diagnóstico. Não há evidências que exista um único gene responsável pelo TDAH. Como na maioria dos transtornos psiquiátricos, observa-se que no TDAH haja genes de efeito reduzido, sendo responsáveis por uma vulnerabilidade para o transtorno.

No tipo desatento ou predominantemente desatento do TDAH observa-se normalmente, bem como no tipo combinado, uma maior taxa de problemas relacionados ao desempenho acadêmico. Indivíduos com predomínio de hiperatidade/impulsividade geralmente apresentam mais problemas comportamentais, com a presença de sintomas como agressividade e impulsividade, afetando as relações sociais. O tipo combinado, por sua vez é o que resulta em maior comprometimento global (ROHDE e colaboradores, 1999).

Enquanto crianças desatentas sofrem freqüentemente com rótulos associados à lentidão para executar tarefas, crianças que apresentam os sintomas de hiperatividade e impulsividade são bastante rejeitadas e impopulares. Há maiores diferenças entre os grupos de desatenção quando comparados com os outros dois grupos tanto do ponto de vista cognitivo, quanto comportamental (CAPDVILA-BROPHY e colaboradores, 
2005; FARAONE e colaboradores, 1998). Diferenças no desempenho neuropsicológico em adolescentes em uma série de provas, incluindo conceitos abstratos, sustentação da atenção, atenção seletiva e funções executivas foram encontradas em um estudo diferenciando principalmente os grupos TDAH dos subtipos combinado e desatento do subtipo hiperativo (SCHIMTZ e colaboradores, 2002). Estes dados apontam para perfis neuropsicológicos diferenciados nos subtipos de TDAH (BYRNE, 1998; MATTOS e colaboradores, 2006a; PENNINGTON, 2005; ROHDE \& HALPERN, 2004; ROMEROAYUSO e colaboradores, 2006).

A neurobiologia do TDAH é heterogênea. Informações de estudos neuropsicológicos, de neuroimagem e de neurotransmissores vêm sendo utilizadas na compreensão do transtorno (ROHDE e colaboradores, 1999, ROHDE e HALPERN, 2004). Disfunções em sistemas de neurotransmissores podem contribuir para o aparecimento de TDAH, principalmente relacionadas à dopamina e à noradrenalina. Por exemplo, associações têm sido descritas entre vários polimorfismos em vários genes monoaminérgicos e o TDAH. Estes incluem os genes dos receptores D1, D4 e D5, o gene Adrenoreceptor A2 e genes associados ao transporte de serotonina (RUSSEL e colaboradores, 2005). Apesar de haver um consenso atual sobre alterações da atividade dopaminérgica no TDAH, diferentes alelos de genes relacionados às funções dopaminérgicas têm sido associados com a alteração diferenciada de funções cognitivas e com os tipos do TDAH. Por exemplo, Lowe e colaboradores (2003) conduziram uma amostra multicentro documentando um efeito pequeno, mas significativo para o gene DRD5 no TDAH combinado e no de predomínio desatento.

Um fator adicional relacionado à neurobiologia do TDAH tem apresentado resultados indicando redução do volume cerebral em pacientes portadores do TDAH, particularmente no córtex pré-frontal, corpo caloso, cerebelo e núcleos da base (DOUGHERT e colaboradores, 1999; KRAUSE e colaboradores, 2000). Há indicações de que a dopamina altera a estrutura e função cerebral. A ação do genótipo do transportador de dopamina DAT 1 (em inglês, dopamine transporter), tem sido estudada porque esta proteína é inibida pelos estimulantes utilizados no tratamento do TDAH (ROHDE \& HALPERN, 2004). O gene do transportador de dopamina DAT 1 foi associado também à redução do volume do núcleo caudado (DURSTON e 
colaboradores, 2005), um sítio subcortical que está associado ao TDAH. Outro gene associado ao TDAH é o gene do receptor D4 de dopamina (DRD4). O produto deste gene concentra-se em áreas do cérebro cujas funções estão prejudicas na doença e parecem influenciar o volume do córtex pré-frontal (BARKLEY, 1997). Este gene foi associado também à característica comportamental "busca por novidades", observada nos portadores do TDAH (ROHDE \& HALPERN, 2004).

As alterações neuropsicológicas e neuroanatômicas encontradas no TDAH parecem estar fortemente associadas aos modelos existentes sobre o transtorno. Uma das primeiras teorias anátomo-funcionais descrevia disfunções das áreas frontais e suas conexões subcorticais no sistema límbico (ROHDE e colaboradores, 2004). A partir desta perspectiva, o TDAH foi compreendido como uma alteração única do controle inibitório frontal dorsal sobre as ramificações mesocorticais dopaminérgicas, resultando em uma disfunção executiva secundária (MATTOS e colaboradores, 2006A). Barkley (1997) propôs o TDAH como sendo a expressão de um déficit de inibição comportamental. Um dos principais problemas deste modelo é sua aplicação ao TDAH do tipo predominantemente desatento. Portadores deste subtipo têm muito mais um problema na sustentação da atenção do que dificuldades para inibir respostas.

Kuntsi e Stevenson (2000) argumentaram que o termo inibição de resposta seria vago como modelo psicológico para explicar o fenômeno descrito. Esses autores descreveram que o modelo de corrida (LOGAN, 1994), poderia ser considerado um modelo explícito de inibição de resposta. Neste modelo, o desempenho de inibição dependeria da resultante entre dois processos: de parada (stop) e ida (go). Se o processo stop termina primeiro, a resposta é inibida. Se o processo go ganha, então a ação em andamento é completada. Neste caso, interferências que produzem consciência sobre um erro podem disparar o processo stop. A proporção de tentativas, nas quais, uma resposta será inibida depende de dois fatores: a distribuição dos tempos finais para os processos stop e go, bem como, o intervalo entre o início dos estímulos para os mesmos processos. Com um modelo de teste do tipo stop-go, Logan (1994) verificou que as crianças com TDAH não apresentaram propriamente um problema na inibição da resposta per se, mas na velocidade para parar e no tempo de reação, ambos os processos aparentemente envolvidos com a teoria da corrida. 
O segundo modelo mais utilizado concebe o TDAH como o resultado de sinalização deficitária de recompensas tardias, secundariamente a alterações nos processos motivacionais que envolvem a circuitaria fronto-ventral para o estriado e ramificações mesolimbicas, em especial as que terminam no núcleo accumbens (SAGVOLDEN e colaboradores, 1998). Riesgo e Rohde (2004) indicaram que uma explicação neuroanatômica para o TDAH envolveria então uma circuitaria neuronal com dois sistemas atencionais: um anterior dopaminérgico, que envolve a região pré-frontal e suas conexões subcorticais (responsável pelo controle inibitório e funções executivas) e outra posterior, primariamente noradrenérgica, que envolve a regulação e atenção seletiva.

No nível dos mecanismos psicológicos subjacentes, há várias hipóteses para explicação do TDAH, dentre as mais importantes: o déficit de atenção, a disfunção executiva (envolve o modelo inibitório supracitado), aversão a intervalo e disfunção de regulação de estado.

Apesar do uso amplo da expressão "Transtorno do Déficit de Atenção/Hiperatividade", pesquisadores têm questionado se déficit de atenção é verdadeiramente o problema central nesta doença. Atenção é um construto multidimensional envolvendo atenção seletiva, dividida e sustentação (KUNTSI e STEVENSON, 2000). A partir da teoria do processamento de informação, van der Meere (1996) reportou que crianças com TDAH não apresentam problemas no primeiro estágio (codificação) e no estágio intermediário (busca de memória e decisão), ou seja, com preservação destes estágios de informação. Estes dados levaram à conclusão de que estas crianças não apresentavam erros de atenção focalizada e dividida. A questão crucial então é se indivíduos com TDAH teriam dificuldade de manter a atenção ao longo do tempo (atenção sustentada).

As dificuldades na tarefa de desempenho contínuo (CPT, em inglês - Continuous Performance Task) parecem ser evidências para o déficit de atenção sustentada. Todavia, van der Meere (1996) constatou que em testes de atenção sustentada, não deve haver somente uma avaliação geral no número de tentativas certas ou erradas, mas que deve ser considerado o desempenho ao longo do tempo. $O$ referido autor utilizou a apresentação da CPT em uma taxa de apresentação bem mais lenta que a 
apresentação normal do teste. Avaliou 12 crianças com TDAH e 12 controles num estudo do tipo duplo-cego, constatando que as crianças com TDAH, ao realizarem o teste com uma apresentação mais lenta, principalmente na ausência do experimentador, tinham um desempenho realmente inferior ao grupo controle ou quando estavam utilizando medicação estimulante. A presença do experimentador melhorou o desempenho; a taxa de estímulo mais lenta piorou o desempenho dos portadores do TDAH e o uso da medicação melhorou o resultado na tarefa de desempenho contínuo. Estes achados mostraram-se úteis para uma interpretação alternativa à presença de um "déficit de atenção" (KUNTSI e STEVENSON, 2000). Estes autores sugerem que não seria uma falta ou déficit de atenção o problema principal no TDAH, mas uma incapacidade sustentação da atenção.

A idéia de que o TDAH esteja relacionada ao circuito neuroanatômico frontoestriatal encontra respaldo em estudos relacionados às Funções Executivas (FE) (BARKLEY, 1992; PENNINGTON e OZONOFF, 1996). As FE referem-se às habilidades cognitivas importantes que capacitam os indivíduos ao desempenho de ações voluntárias, independentes, autônomas e orientadas para metas específicas (MATTOS e colaboradores, 2003). Envolvem habilidades de auto-regulação e auto-manutenção, controle de interferências, integração entre tempo e espaço, planejamento, antecipação de conseqüências e memória operacional. Algumas características das FE são claras e referem-se: 1) ao controle voluntário e consciente sobre o ambiente circundante e sobre a ação necessária para administrar contingências em função de um objetivo; 2) à integração da percepção e ação; 3) a não ser uma entidade única, englobando processos de controle de função distintos; 4) à integração de dimensões cognitiva, emocional e social (SANTOS, 2004). Segundo Welsh e Pennington (1988), embora a definição do termo seja bastante ampla, tipicamente as FE envolvem um conjunto de habilidades para solução de problemas e direção para objetivos futuros envolvendo um ou mais dos seguintes aspectos:

a) uma intenção de inibir a resposta ou postergá-la para uma hora melhor;

b) um plano estratégico de seqüência de ações; e/ou

c) uma representação mental da tarefa incluindo informação relevante sobre estímulos codificada na memória e dirigida a um objetivo futuro. 
Estudos envolvendo indivíduos com TDAH revelaram diferenças entre as FE neste grupo e em indivíduos saudáveis. Pennington e Ozonoff (1996) fizeram uma revisão em 18 artigos, em que 15 descreveram algum tipo de comprometimento das FE's em indivíduos com o transtorno. Um dos principais problemas na definição do TDAH, como uma síndrome de alteração das funções executivas, inclui dificuldades relacionadas às definições vagas e medidas ainda imprecisas, para este grupo especial de habilidades. Neste sentido, o problema central parece ser uma delimitação do que seria identificado e mensurado como FE nos testes neuropsicológicos. Por exemplo, testes como a Torre de Hanói são desenhados para avaliação de FE, mas também se aplicam à habilidades cognitivas espaciais. Stuss e Alexander (2000) indicaram que muitos testes de FE são multifatoriais e o baixo desempenho poderia ser explicado por outras razões, que não um mau funcionamento dos lobos frontais.

Um problema adicional, quando se aceita que a maior parte das FE's esteja associada aos lobos frontais, é que as alterações no TDAH parecem depender também de outros circuitos, por exemplo, conexões com o córtex parietal associativo. Resumir o TDAH como um problema exclusivo de FE pode ser teoricamente viável, mas há limitações relacionadas entre este modelo teórico psicológico e as alterações neurofuncionais presentes no transtorno. Além disso, é bastante difícil encontrar condições clínicas limitadas ao lobo frontal, talvez com a exceção da demência do lobo frontal em estágios iniciais (STUSS e ALEXANDER, 2000). Por outro lado, dois componentes centrais parecem ser comuns na FE: a memória operacional e a capacidade para inibição de resposta, condições claramente alteradas em portadores do TDAH.

Duas outras teorias psicológicas também têm encontrado respaldo na literatura. Ao testarem a hipótese de inibição de resposta e funções executivas em indivíduos com TDAH, Sonuga-Barke e colaboradores (1992) consideraram uma hipótese alternativa para indivíduos portadores do TDAH: crianças hiperativas têm Aversão ao Atraso (Delay Averse Theory).

Numa tarefa, Sonuga-Barke e colaboradores (1992) solicitaram que a criança escolhesse se queria receber um reforço pequeno (1 ponto) ou grande ( 2 pontos). Numa primeira condição (sem intervalo), se a criança optasse pelo reforço pequeno, ela 
o receberia após dois segundos. Se escolhesse o grande, recebia-o após 30 segundos. Logo após, independente da escolha, podia-se realizar uma nova escolha de reforço. $\mathrm{Na}$ condição pós-intervalo, a condição de tempo de reforço se invertia para o reforço pequeno e grande. Após alcançar 30 pontos a tarefa era interrompida. As crianças hiperativas esperaram 30 segundos quando isso era adequado, ou seja, ganhar mais pontos. Também não diferiram quando tinham que escolher o reforço no tempo menor.

Duas hipóteses foram derivadas desta tarefa: primeira, as crianças hiperativas eram maximizadores de reforço; segunda, tratou-se da aversão à espera: o tempo de intervalo na tarefa determinou intensamente a escolha das crianças hiperativas, dar-seia apenas preferência ao reforço imediato se isso reduzisse a espera como um todo. Os investigadores realizaram uma nova tarefa onde a criança agora tinha 10 minutos: na primeira condição, para escolher entre o reforço imediato pequeno ou o reforço grande com atraso; numa segunda condição, as crianças podiam escolher o reforço por 20 vezes, na qual escolher o reforço grande era a melhor opção. Na primeira condição (que foi associada ao intervalo de tempo de 2 e 30 segundos), o desempenho entre os grupos foi igual. Entretanto, na segunda condição, associada ao número de tentativas, as crianças com TDAH escolheram o reforço grande (mais demorado) um número menor de vezes. Estas respostas sugerem que os indivíduos portadores do transtorno apresentaram maior aversão ao atraso do que aqueles que seriam maximizadores de reforços. Eles não só receberam menos pontos, como também desejaram menos esperar pela recompensa maior após intervalo prolongado.

Kuntsi e Stevenson (2000) sugeriram que o déficit cognitivo observado possa ser na realidade um problema motivacional. Sonuga-Barke (1994) conjecturou que o problema seria motivacional relacionado à aversão ao atraso e que, esta hipótese poderia explicar tanto a impulsividade, como a desatenção e a hiperatividade. Quando é inviável evitar o intervalo ou espera, as crianças com TDAH tendem a focalizar em aspectos ambientais que reduzem sua experiência subjetiva relacionada à espera, resultando em desatenção. Outra estratégia para lidar com a espera seria a movimentação aumentada, comportamento que estaria relacionado a hiperatividade.

Essa teoria difere das demais consideradas, por não relacionar a criança com a hiperatividade, como portadora de um déficit. Assim, o TDAH não deveria ser 
considerado como uma disfunção psicológica, mas uma resultante do fato de que essas crianças têm objetivos diferentes de outras crianças não portadoras (SONUGA-BARKE, 1994).

Outro grupo de teorias psicológicas sobre o TDAH denominadas como Teorias da Disfunção da Regulação-Estado, podem ser assim sumarizadas:

a) Teoria da Estimulação Ótima, que preconiza "portadores do TDAH têm um nível de alerta abaixo de não portadores", evidenciada pelas situações onde o desempenho de crianças hiperativas parece ser similar ao de crianças sem o TDAH (novidades, jogos ou atividades em "play-grounds"). Consideram que a redução da estimulação ambiental ou a diminuição de fatores de novidade pode aumentar a hiperatividade e a desatenção (KUNTSI e STEVENSON, 2000);

b) Teoria da Regulação-Estado, que critica uma única conceituação de sistema de alerta. Parece haver um sistema de multi-estado. Alerta e ativação são funções ou estados diferenciados, onde o primeiro parece depender de noradrenalina e serotonina, enquanto o sistema de ativação parece depender mais de acetilcolina e dopamina. Além disso, o sistema nervoso cuida em diferentes centros dessas funções, estando o primeiro associado às vias fronto-límbicas, enquanto o sistema de ativação estaria associado aos núcleos da base. Haveria ainda um terceiro sistema envolvido que é o sistema de esforço, que funcionaria como um controle dos sistemas de alerta e ativação. Se o sistema de alerta não é ótimo, então o sistema de esforço controla isso. Alguns exemplos clínicos associados a este modelo incluem fatores motivacionais tais como pagamentos, presença ou ausência do experimentador e conhecimento de resultados (van der MEERE, 1996). Para o autor, a hiperatividade seria explicada por um padrão lento de resposta e de baixa acurácia. Uma forma de compreender a teoria da regulaçãoestado seria o da comparação do sistema de alerta com um motor (que faria o processamento de informação), no qual faltaria combustível (a capacidade cognitiva depende de fatores como, incentivos, taxas de apresentação de eventos, dentre outros). O relato dos pais parece ser compatível com essa teoria, onde aparentemente o "déficit" parece apresentar-se somente em condições tediosas. 
Aparentemente, ainda que haja poucos estudos relacionando teorias psicológicas com achados neuroquímicos e neuroanatômicos, parece haver uma tendência para integração desses modelos (KUNTSI e STEVENSON, 2000; STEVENS e colaboradores, 2002). Há estudos relacionando alterações neuropsicológicas: funções executivas, atenção, memória operacional, bem como outras investigações associadas às disfunções neuroquímicas e comprometimentos cognitivos, acadêmicos e comportamentais associados.

Pastura e colaboradores (2005) demonstraram que o TDAH está associado a mau desempenho escolar (MDE). Alterações atencionais como erros de desempenho, escolhas apressadas e baixa avaliação de alternativas parecem ser alguns dos fatores que interferem com o MDE no TDAH. Por outro lado, dificuldades de aprendizagem, que não são caracterizadas como Transtornos de Aprendizagem (Dislexia, Discalculia e Disgrafia) são comuns em portadores do TDAH. Alguns dos critérios para avaliação de MDE são: notas baixas, suspensão, repetência, pontuação abaixo do esperado em testes de coeficiente de inteligência (QI) e desempenho abaixo do esperado em termos absolutos em testes padronizados. Há indícios que, além dos recursos oferecido pela escola, escolaridade parental, nível sócio-econômico, qualificação do professor e do próprio indivíduo (ARAÚJO, 2002), outros fatores associados ao funcionamento cognitivo interferem com o desempenho acadêmico.

Queixas relacionadas à atenção e memória são efetivamente os problemas mais comuns, traduzidos nos sintomas descritos no DSM-IV (AMERICAN PSYCHIATRIC ASSOCIATION, 1994). Essas alterações em funções parecem ser compatíveis com as características de aprendizagem no ambiente escolar, na vida diária e relacional de pacientes portadores do TDAH. Para compreensão sobre a atenção e memória no TDAH faz-se necessária uma melhor compreensão dos sistemas e processos envolvidos nestas funções. 


\subsection{Processos de Atenção e suas disfunções relacionadas ao TDAH}

Para a compreensão da atenção, deve-se considerá-la primeiramente como um fenômeno que envolve várias etapas que levam à priorização no processamento de certas categorias de informação (HELENE e XAVIER, 2003). Aparentemente, a atenção - assim como outros processos que envolvem o sistema nervoso (SN) - é resultado da interação de dois processos: a) do ambiente para o $\mathrm{SN}$, no qual há o aprendizado de informações a partir das experiências, sendo regulado por condições temporais e espaciais; b) a partir do acúmulo destas experiências, que passam a ocorrer do SN para o ambiente. Assim, o primeiro caracteriza um funcionamento bottom-up (de-baixo-paracima) e o segundo um funcionamento do tipo top-down (de-cima-para-baixo), envolvendo progressivamente previsões probabilísticas sobre o ambiente (CAMPOS e colaboradores, 1996; HELENE e XAVIER, 2003). Assim, o SN parece atuar na geração de ações para um determinado alvo e também direcionando a sua atenção, através de um processo ativo de seleção (HELENE e XAVIER, 2003).

Estas considerações são importantes, pois, se a atenção funciona de forma integrada, e não como um processo isolado da condição de aprendizagem, vários seriam os fatores possíveis de influenciar o desempenho atencional, quais sejam: a familiaridade com material apresentado em testes; os efeitos de treinamento e ainda, fatores motivacionais. A atenção envolve processos de seleção e manutenção que são explicados por várias teorias que incluem tanto o estágio no qual se dá o processamento da informação quanto os processos associados.

Os testes para verificar decrementos no processamento atencional englobam funções vinculadas à atenção. Uma vez que não existe consenso, no que se poderia denominar atenção, a verificação dos processos gerenciados por essa função parece contribuir mais à compreensão da atenção.

Sternberg (2000) caracterizou a atenção por "um fenômeno pelo qual processamos ativamente uma quantidade limitada de informações do enorme montante de informações disponíveis através de nossos sentidos, de memórias armazenadas e de outros processos cognitivos". Apesar desta definição ser relativamente bem aceita, aparentemente, se aplica mais a uma das tarefas da atenção (a seletiva) do que a 
ampla variação de processos atencionais. Assim, parece que uma definição sobre atenção deveria envolver: a) uma noção de alerta, preparando o indivíduo para respostas ao ambiente; b) respostas de orientação, que deveria funcionar como um precursor para a vigilância; c) atenção seletiva, permitindo a inibição de estímulos irrelevantes; e d) atenção adaptativa, permitindo o ajuste da atenção a modificações ambientais (PISTOIA e colaboradores, 2004).

Barkley (1996) considerou que a atenção seja um construto multidimensional, desempenhando uma relação funcional entre eventos em um contexto e a forma de responder a estes, sendo classificados como objetos e suas qualidades, ações provenientes do ambiente e características dos eventos em si. Respostas, imediatamente conseqüentes à ocorrência dos eventos, seriam então classificadas como reações de atenção, sendo esta característica denominada "proximidade temporal", a marca distintiva entre atenção e funções executivas. Ainda que o modelo proposto não responda a uma pergunta específica sobre o que é atenção, o conceito "proximidade temporal" auxilia na compreensão da função. $O$ modelo para compreensão desta representação é apresentado na Figura 1.

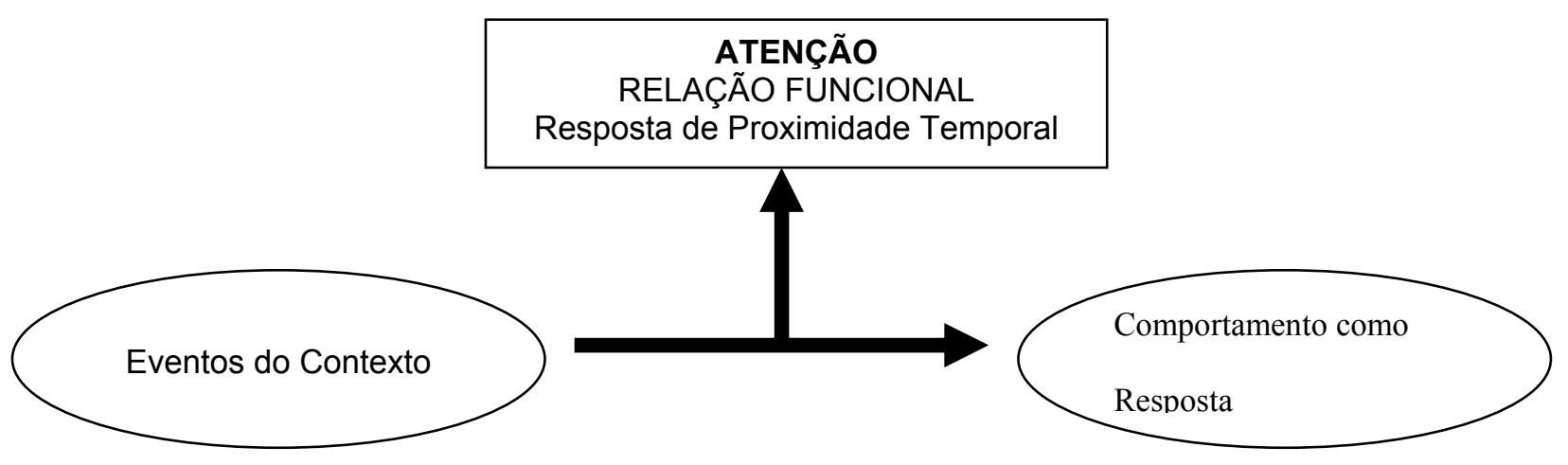

Figura 1 - Modelo de Relação Funcional da Atenção (BARKLEY, 1996)

A idéia relacionada a um componente de temporalidade parece ser compatível não apenas com o construto atencional, mas relaciona-se diretamente com funções atencionais. Classicamente, testes atencionais envolvem tempo de reação como um componente das respostas atencionais. Neste sentido, a emissão de uma resposta mais rápida parece efetivamente ser um fator que está envolvido com o desempenho 
atencional (MIRSKY, 1987), concomitante aos fatores como número de omissões e erros de seleção.

Lezak e colaboradores (2004) comentaram que à avaliação de atenção, além dos aspectos de vigilância, deveriam ser incluídas: a memória de curta duração, as estratégias mentais de processamento atencional e a atenção complexa. A capacidade de vigilância é verificada em tarefas que exigem a manutenção da atenção por períodos prolongados. As tarefas que exigem o registro temporário de informações são tipicamente associadas tanto à memória de curta duração como à memória operacional. As estratégias mentais caracterizam-se por condições de habilidades desenvolvidas, que parecem interferir com o processo atencional. Para atenção complexa, os testes que indicam o uso de mais de uma função atencional (concentração e alternância) parecem funcionar como instrumentos válidos de detecção.

Das variações de classificação de atenção e de suas variantes parece haver uma tendência à aceitação de quatro funções da atenção. Elas podem ser compreendidas à luz da avaliação neuropsicológica, e da compreensão dos processos cognitivos subjacentes ao funcionamento normal ou alterado, como observados no TDAH, e descritas como: a) atenção seletiva, envolvendo a seleção ativa de determinados estímulos e inibição daqueles que são observados como irrelevantes; b) vigilância, que envolve a sustentação da atenção e a expectativa de deteç̧ão de um novo estímulo; c) sondagem, na qual, busca-se ativamente estímulos particulares; d) atenção dividida, que distribui recursos atencionais para coordenar o desempenho em mais de uma tarefa ao mesmo tempo (STERNBERG, 2000), permitindo a habilidade de mudar o foco de um estímulo para outro no ambiente de maneira adaptada (MIRSKY, 1987).

A atenção seletiva é uma função que permite escolher determinados estímulos e diminuir o foco sobre outros, foi descrita inicialmente em um importante estudo conhecido como o "problema do coquetel", no qual, os participantes foram submetidos a uma tarefa de escuta dicótica (com mensagens diferentes) ou biauricular, ou seja, os sujeitos ouviam mensagens iguais nos dois ouvidos (STERNBERG, 2000). Verificou-se que os sujeitos consideraram mais fácil identificar mensagens dicóticas, na qual utilizavam atenção seletiva auditiva, do que quando a mensagem era biauricular, o que dificultava a compreensão da mensagem, que derivaram em estudos, os quais, 
apontaram para uma mudança no conceito de atenção seletiva. O deslocamento atencional, resultante da atenção seletiva, parece ser uma condição facilitada tanto pelo substrato neurobiológico quanto cognitivo.

Nakai e colaboradores (2005), utilizaram ressonância magnética funcional e uma técnica de comparação de mapas para comparar o desempenho de indivíduos normais em tarefas de escuta dicótica e biauricular. Eles constataram que houve ativação diferenciada de sítios cerebrais em tarefas auditivas dicóticas (vozes diferentes) quando comparados com o desempenho nas tarefas biauriculares (com a mesma voz). As regiões mais ativadas foram: os giros pré-central esquerdo, frontal medial direito, supramarginal direito e o opérculo frontal direito. Os resultados sugerem ainda, o recrutamento de regiões do giro frontal medial na tentativa de discriminação de vozes, parecendo requerer componentes de memória operacional para este tipo de diferenciação.

Dificuldades de atenção seletiva parecem ser características nos casos de TDAH, pois freqüentemente indivíduos portadores do déficit parecem falhar na escolha do objeto a ser selecionado como foco de atenção. Por exemplo, as dificuldades escolares manifestadas pelas decisões apressadas sem considerar todas as alternativas possíveis (PASTURA, MATTOS e ARAÚJO, 2005), podem ser decorrentes destas falhas. Neste caso, dois processos parecem estar envolvidos: o deslocamento atencional quanto à seleção per se. Em ambos os casos, pode-se observar falhas nos processos de memória operacional, com prejuízos na recordação de um estímulo anterior e na avaliação de sua importância para uso.

A memória operacional é um conceito hipotético relacionado ao arquivamento temporário da informação, para o desempenho de uma diversidade de tarefas cognitivas (HELENE e XAVIER, 2003). Além da história prévia do sistema atencional selecionador, expectativas geradas sobre a pendência de eventos futuros parecem contribuir para os sistemas de atenção seletiva. Baddeley (2000), na revisão de seu modelo de memória operacional, considerou a inserção de um quarto componente ao modelo de memória operacional inicial (BADDELEY e HITCH, 1974), no qual, além da central executiva e das alças fonológica e viso-espacial, há o retentor episódico que 
corresponderia a um sistema de capacidade limitada, em que a informação evocada da memória de longa duração tornar-se-ia consciente.

Qual a importância deste modelo para a compreensão do funcionamento de atenção? O funcionamento da central executiva parece depender de um Sistema Atencional Supervisor (SAS). Este sistema estaria envolvido no controle de ações e parece ser ativado sempre que novas atividades estão envolvidas ou quando um estímulo urgente ou ameaçador é apresentado. O envolvimento do SAS com a memória parece ser evidente, por exemplo, na aquisição de conhecimento implícito. Shallice e Burgess(1991) indica uma equivalência temporal entre os processos de aquisição de memória implícita e do SAS. Este processo de equivalência ocorreria mesmo na ausência de treinamento específico para aquisição de uma tarefa. Disfunções do lobo frontal parecem gerar dificuldades no funcionamento do SAS (SHALLICE, 1991). Por outro lado, o funcionamento do SAS não está limitado ao lobo frontal. Então, disfunções em outros sítios poderiam gerar alterações no SAS.

Em provas de planejamento, inibição e abstração, pacientes com lesões restritas ao lobo frontal não apresentaram diferenças de indivíduos sem lesão cerebral, incluindo os testes Torre de Londres, Haylin e Brixton. Os resultados sugerem o envolvimento de regiões adjacentes e circuitaria extrafrontal para o SAS. Por outro lado, alterações do funcionamento atencional como perseverança comportamental e aumento da distratibilidade têm sido observados como efeitos de lesões do lobo frontal (SHALLICE, 1988). A deficiência no funcionamento do SAS implicaria numa ou outra possibilidade: (1) omissão à inibição do esquema hiperativo, em função da preponderância da atividade em um esquema ativado ou; (2) impossibilidade na seleção de uma ação, gerando distratibilidade, com ativação concomitante de diversos esquemas. Neste caso, não há a predominância da ativação de um dos esquemas sobre os demais.

A ativação de vários esquemas concomitantes sem preponderância de nenhum deles e/ou a ativação exacerbada de alguns esquemas parecem explicar satisfatoriamente os erros cometidos na atenção seletiva por indivíduos portadores do TDAH. Por outro lado, Barkley (2002a) referiu que crianças com TDAH não teriam problemas para filtragem de informações, ou seja, em distinguir o importante do irrelevante naquilo que são solicitadas a fazer. Neste caso, o problema poderia estar 
associado mais provavelmente a uma dificuldade para manutenção da atenção e não a erros na seleção de uma tarefa.

Diamond (2005) ressaltou que o problema principal nos indivíduos com TDAH do subtipo desatento estaria associado à memória operacional (uma FE), enquanto nos sujeitos que apresentam o TDAH do subtipo hiperativo, o déficit estaria associado ao controle inibitório e motor. Este autor baseou-se no conceito que a memória operacional envolve a habilidade de (a) manter informação selecionada de maneira ativa e evocável e (b) inibir ou bloquear outras informações de entrarem nesta forma ativa (KANE e ENGLE, 2002). Há evidências crescentes de que o córtex pré-frontal dorsolateral seja uma estrutura crucial numa rede para o controle de áreas anterior e posterior envolvidas na atenção. Aparentemente, esta região parece exercer uma função bastante importante tanto na seleção atencional quanto para inibir e informações não relevantes (KANE e ENGLE;2002; STUSS e ALEXANDER, 2000; VALERA e colaboradores, 2005).

Diamond (2005) argumentou que a inibição de informações concorrentes e a manutenção da informação para manipulação são funções independentes, mas o desempenho dessas duas funções, concomitantemente requer o envolvimento do córtex pré-frontal. Esse conceito dá suporte a idéia de que o déficit na memória operacional seria mais restrito ao TDAH do subtipo desatento ou simplesmente transtorno do déficit de atenção (TDA) e não seria característica dos subtipos combinado e hiperativo. Estas alterações poderiam explicar as falhas de atenção seletiva destes indivíduos, como conseqüência das dificuldades de manutenção e manipulação das informações. Adicionalmente, como argumenta Barkley (2002a), as falhas não seriam derivadas de problema de filtragem atencional. Os portadores do TDAH distinguiriam o importante do irrelevante.

Nigg (2001) e Nigg e Casey (2005) sugeriram alternativamente, que a dificuldade no TDAH é provavelmente devida a falhas em dois processos envolvendo erros de predição. Primeiramente, o portador do transtorno pode ter dificuldades para ajustar a atenção quando é violada sua expectativa, ou ainda se a predição é ineficiente sobre um estímulo que irá ser apresentado. O segundo processo é uma falha para ajustar o comportamento quando acontece algo que não era esperado. Estas predições 
relacionadas a o "que e quando" parecem estar envolvidas em uma miríade de déficits cognitivos associados ao TDAH. Portadores do TDAH apresentam dificuldades relacionadas à impulsividade e emitem respostas errôneas. Uma predição ruim sobre um estímulo pode gerar uma resposta disfuncional, precipitada e desajustada para o contexto.

Aparentemente, indivíduos portadores do TDAH têm mais problemas relacionados à fixação da atenção em algumas coisas por mais tempo do que em outras. Freqüentemente parecem lutar com tenacidade para manter a atenção em atividades mais longas que as usuais, principalmente as que são mais repetitivas (BARKLEY, 2002a). Nigg e colaboradores (2002) e Nigg e Casey (2005) referiram que o fenótipo comportamental, cognitivo e neuropsicológico do TDAH está relativamente bem caracterizado, incluindo (a) em condições, por exemplo, de testes com estímulos lentos e que exigem respostas cuidadosas, estas normalmente são rápidas e inapropriadas (impulsividade). Um exemplo seria as avaliações escolares que exigem leitura criteriosa e interpretação; (b) em contextos quando a resposta deve ser rápida, as respostas são lentas e pouco precisas. Por exemplo, novamente no contexto escolar as avaliações com tempo definido, quando geralmente os portadores solicitam um tempo extra. Esta carcacterística é denominada de "logomarca hipoalerta" no TDAH; (c) em contextos que exigem decisão rápida, a habilidade para interromper uma resposta é prejudicada (falha na inibição de resposta); (d) quando respostas de organização complexa são requeridas, o funcionamento executivo é deficitário no planejamento, memória operacional e integração; (e) atrasar a recompensa é particularmente difícil; (f) o processamento de informação temporal é afetado, com uma tendência a hiperestimar intervalos de tempo. Pelo menos duas destas características, "a" e "d", parecem estar vinculadas às dificuldades de sustentação da atenção.

Uma vez que o TDAH é uma desordem no desenvolvimento (AMERICAN PSYCHIATRIC ASSOCIATION, 1994; KING e colaboradores, 1998), falhas na consolidação de circuitos cerebrais fronto-estriatais e fronto-cerebelares parecem contribuir para estes sintomas, os quais levam ao comprometimento na sustentação da atenção. Assumindo que estas vias servem para recrutar controle de "cima-para-baixo", quando detectam mudanças no ambiente (HELENE e XAVIER, 2003), então podem 
ocorrer alterações no seu funcionamento. O resultado pode ser de recrutamento préfrontal ineficiente para mudar e/ou manter controle comportamental em diferentes contextos (NIGG e colaboradores, 2002). Geralmente, esta alteração se manifesta com atenção sustentada pobre em tarefas complexas (mudanças ambientais não são processadas adequadamente); respostas lentas em contextos de decisão rápida (falhas na computação de novas informações); dificuldades em saltar de uma resposta a outra e resposta ineficiente para mudar reforços ou aprender contextos.

Diamond (2005) argumentou que as crianças desatentas apresentam um tempo de reação bastante lento, identificando os portadores como letárgicos, hipoativos, orbitantes, sonhadores acordados, sonolentos e com uma percepção lenta do tempo (CARLSON e MANN, 2002). Nos indivíduos portadores do déficit, os sistemas de controle voluntário ou controlado (HELENE e XAVIER, 2003) parecem especialmente difíceis de serem ativados eficientemente.

O "tempo de reação" é bastante importante na avaliação de indivíduos com TDAH, considerando-se que possa ser um indicador de processamento lento. Westerberg e colaboradores (2004) demonstraram que o desempenho em tarefas de escolha com tempo de reação e em tarefas complexas de extensão de dígitos, foram significativamente piores para crianças com TDAH e bem melhores como recursos de avaliação do que uma tarefa de desempenho contínuo ou uma medida do tipo go/no-go. Fischer e colaboradores (2005) constataram que indivíduos adultos, também têm um desempenho inferior em tarefas computadorizadas de tempo de reação que envolvem o uso de inibição de respostas. Esta mesma tarefa foi aplicada anteriormente em crianças, onde foram observadas variações e lentificação no tempo de resposta (ALVAREZ e FREIDES, 2004; BARKLEY, 1997; FUGGETTA, 2006). Uma vez que indivíduos com TDAH não apresentem problemas para filtrar ou selecionar a informação, é provável que a distração seja melhor explicada pelas condições associadas à lentificação e alterações nas funções de memória operacional. Em tarefas do tipo go/no-go, que recrutam atenção seletiva, as dificuldades apresentadas poderiam, provavelmente, ser explicadas por dificuldades relacionadas à alternância e não propriamente por uma falha na seleção. 
Sheppard e colaboradores (1999) detectaram problemas de atenção seletiva em crianças, usando um teste de bi-secção de linhas apresentadas em uma tela de computador, comparando três grupos amostrais: 1) crianças portadoras do TDAH, ainda não medicadas; 2) crianças portadoras do TDAH, medicadas; 3) controle, composto de participantes não portadores de TDAH. As crianças do grupo 1 realizaram os cortes com mais eficácia, quando eram apresentadas as linhas mais à direita que a esquerda na tela do computador, enquanto os participantes do grupo 2 tiveram um desempenho similar aos dos participantes do grupo controle.

Os referidos autores sugeriram que a teoria de função hipoalerta do hemisfério direito $(\mathrm{HD})$ poderia justificar o número maior de linhas não seccionadas à esquerda. $\mathrm{O}$ desempenho inferior das crianças portadoras do TDAH, foi adicionalmente explicado pela disfunção lateralizada da circuitaria frontoestriatal do hemisfério direito no TDAH. O número menor de linhas não seccionadas no teste se contrapõe à idéia de que estes indivíduos não teriam dificuldade para selecionar a informação. Por outro lado, um fator que deve ser considerado é que a sustentação da atenção apresentou-se com erros, o que foi denominado "efeito da seqüência temporal". Este efeito se mostrou presente no terceiro bloco de 20 tentativas, para os sujeitos com TDAH, não medicados. À medida que a tarefa tornou-se mais familiar, os níveis de alerta e atenção sustentada foram reduzidos.

Esses resultados sugerem uma interessante conclusão: os níveis de atenção na tarefa teriam sido mais dependentes da extensão da mesma do que propriamente de erros da atenção seletiva. Uma explicação adicional refere-se ao uso da memória operacional, por exemplo, diferenças individuais na memória operacional correspondem também a diferenças individuais na atenção seletiva (CONWAY e colaboradores, 1999; KANE e colaboradores, 2001). É possível, que as diferenças relacionadas à atenção seletiva tenham sido dependentes da baixa sustentação de informações, estas necessárias para uso ao longo da tarefa.

As tarefas de atenção sustentada utilizam ocorrência eventual de um estímulo a fim de avaliar o desempenho. Um sinônimo para esta função é o conceito de vigilância que se refere à "capacidade de uma pessoa estar presente em um campo de estimulação durante um período prolongado, no qual ela procura detectar o 
aparecimento de um sinal, um estímulo-alvo, de interesse" (STERNBERG, 2000). A vigilância inclui o conceito da entrada de um estímulo esperado, o que pode envolver neste caso uma expectativa relacionada ao mesmo em função da experiência prévia, como sugerido por Helene e Xavier (2003).

Um componente importante relativo à expectativa de eventos futuros e que auxilia na sustentação da atenção por tempo prolongado, foi descrito por Diamond (2005). Este componente, denominado motivacional, parece ser crucial para explicar que em vez de facilmente distraídas, pessoas com TDA são facilmente entediadas. $\mathrm{O}$ autor sugere que o problema relacionado à manutenção da motivação seria mais importante do que o da inibição da resposta.. A hipótese do componente motivacional modifica o foco da distração de um elemento externo relacionado a um estímulo insuficiente para manter uma resposta, para uma explicação da distração como interna ou externa. Esta distração seria uma resultante da redução progressiva do interesse do indivíduo (Diamond, 2005). Sergeant e colaboradores (2003) sugeriram um modelo cognitivo-energético similar, mas com um foco maior em uma reação irregular para o reforço, o que colocaria a motivação para sustentação da atenção como dependente de uma apresentação regular de recompensas.

No modelo motivacional proposto por Diamond (2005), a desatenção progressiva e a distração que comprometem a sustentação da atenção parecem ser compensadas, quando o indivíduo encontra situações que os desafiem. Por exemplo, crianças com TDAH têm desempenho normal em tarefas de desempenho contínuo como a continuous performance task (van der MEERE e colaboradores, 1991), quando expostas a uma taxa mais rápida de apresentação dos estímulos. Mesmo indivíduos com TDAH que são comportamentalmente mais reservados respondem a tarefas desafiadoras com um nível de engajamento que geralmente é bastante difícil em outras atividades do dia-a-dia.

Uma razão adicional para a redução motivacional parece encontrar suporte na hipótese neural de que haveria uma diminuição nas taxas de sinalização celular, principalmente em indivíduos com TDAH de predomínio desatento, o que parece ser consistente com uma velocidade de processamento reduzida. Sustentar a concentração em informações que devem ser relembradas e integradas torna-se mais desgastante 
para indivíduos com o déficit. Assim, estes indivíduos poderiam queimar sua reserva numa tarefa mais precocemente, necessitando de um maior estímulo para preencher novamente o sistema. Quando suficientemente motivados e sob circunstancias adequadas, crianças com desatenção podem ter bom desempenho, mas é difícil para elas sustentarem o nível de desempenho por longo prazo (CORKUM e SIEGEL, 1993).

A atenção dividida é uma condição onde o sistema atencional deve executar duas ou mais tarefas distintas concomitantemente (STERNBERG, 2000). Neisser e Becklen (1975) utilizaram uma tarefa na qual indivíduos deveriam selecionar uma atividade e ignorar outra, mas que resultou em uma avaliação de atenção seletiva.. Spelke e colaboradores (1976) compararam crianças com TDAH em duas tarefas. Os sujeitos foram comparados em duas tarefas com três condições; uma delas envolveu a realização de tarefas concomitantes. Para tanto, os pesquisadores propuseram uma medida de tempo de reação e exatidão do desempenho, em duas tarefas que exigiam processos controlados de atenção. Os indivíduos deveriam compreender um texto lido e escrever palavras ditadas ao mesmo tempo. Tanto o tempo de reação quanto a exatidão foram comprometidos em sujeitos com diagnóstico de déficit atencional. A situação se modificou quando os indivíduos foram levados a treino subseqüente prolongado, melhorando o desempenho geral no tempo de reação, que foi medido através da redução da latência das respostas e da eficácia da resposta.

Pashler (1994) verificou que quando as pessoas tentam executar duas tarefas sobrepostas que exigem respostas rápidas, a resposta para uma ou ambas são lentas. Se uma tarefa começa pouco depois que a primeira iniciou, a velocidade de execução na geralmente fica reduzida. Esse efeito é chamado de período psicológico refratário (PPR), sendo explicado pelo fato de que pessoas podem perceber as propriedades físicas dos estímulos sensoriais, quando estão envolvidas em uma segunda tarefa rápida. O problema é que nesta condição, a adaptação para uma tarefa cognitiva que exija a escolha de uma resposta é reduzida a evocação de informação proveniente da memória ou envolvimento em várias operações cognitivas ficam prejudicados. Esta baixa adaptação piora o desempenho final em duas tarefas alterando a velocidade de execução. 
Carlson e colaboradores (1991) utilizaram a técnica de tarefas duplas em duas condições para avaliar meninos portadores do TDAH, com ou sem uso de metilfenidato ou placebo. Na primeira condição, a tarefa consistiu na adição de números simples em uma tela de computador e em seguida uma segunda tarefa, que consistiu em responder pisando em um pedal o mais rápido possível após o aparecimento de um tom imediatamente antes ou depois primeira tarefa. Crianças com TDAH com uso de placebo tiveram um desempenho mais lento nas duas tarefas. Na segunda condição, denominada de tarefa dupla, na qual, as duas tarefas não eram sobrepostas em tempo, o grupo placebo mostrou dificuldades na acurácia aritmética e para manter a velocidade na segunda tarefa. Já os participantes com TDAH medicados mantiveram a acurácia na primeira tarefa e reduziram a velocidade no tempo de reação ao estímulo na segunda tarefa.

Os resultados sugeriram que as crianças com TDAH falharam em alocar seus recursos cognitivos para uma tarefa primária quando foi inserida imediatamente uma segunda tarefa concomitante. Carlson e colaboradores (1991) demonstraram que os portadores do TDAH não medicados apresentaram dificuldade na focalização em processos duplos complexos e na alternância de recursos cognitivos entre a segunda e a primeira tarefa apresentadas. Estas falhas observadas neste tipo de testes são evidenciadas no dia-a-dia de indivíduos portadores do TDAH, com erros freqüentes, relativos à escolha e alternância no que seria realmente importante. Estes indivíduos são comumente distraídos por estímulos menos relevantes após o inicio de tarefas importantes. Algumas idéias sobre estas falhas podem incluir erros na memória operacional induzindo a um julgamento equivocado da importância de determinado estímulo (NIGG, 2001; NIGG e CASEY, 2005).

Os indivíduos com TDAH têm mais dificuldade para redirecionar a atenção em tarefas duplas, apresentadas concomitantemente mais do que quando as tarefas são estruturadas e contínuas (FUGGETTA, 2006). Uma explicação adicional é que este tipo de dificuldade parece estar envolvido com funções executivas, no que tange à organização em tarefas complexas e duplas. Cepeda e colaboradores (2000) e Kramer e colaboradores (2001) examinaram o processo de controle envolvido em inibir o desempenho em uma tarefa e preparar para uma nova tarefa. A investigação envolveu 
alternância entre duas tarefas: na primeira, os participantes deveriam decidir quantos números eram apresentados numa tela de computador; na segunda, deveriam discriminar o valor de um número apresentado na tela. O desempenho dos portadores de TDAH foi inferior. Em ambos os trabalhos referidos, os pesquisadores demonstraram que o tratamento com metilfenidato melhorou a habilidade para responder com maior rapidez e eficácia, inibir respostas inapropriadas e preparar para uma nova tarefa.

O modelo de inibição de resposta contribuiu para compreensão dos déficits de atenção dividida, apresentados por indivíduos portadores do TDAH (BARKLEY, 1997). O problema parece inerente à aplicação deste modelo para explicar as variações de déficits atencionais apresentados por estes indivíduos, e, mais particularmente, a aparente inaplicabilidade do modelo ao TDAH do subtipo desatento (BARKLEY, 1997; QUAY, 1997). Por outro lado, a falta de inibição é considerada como o déficit central na teoria de Barkley para o TDAH (FOLEY NICPON e colaboradores, 2004). A teoria de Barkley propôs também explicação para o desenvolvimento falho e atrasado nos indivíduos portadors do TDAH a partir de quatro funções executivas alteradas, conforme segue: (a) memória operacional; (b) auto-regulação do afeto, motivação e alerta; (c) internalização da fala; e (d) habilidade de reconstituir eventos do passado e de antecipar eventos futuros.

Evidências de estudos com neuroquímica e neuroanatomia parecem dar suporte às diferentes funções da atenção. Por exemplo, Konrad e colaboradores (2005), revisando um dos modelos neurais subjacentes ao funcionamento da atenção, reportaram redes neurais e neurooduladores específicos, para diferentes funções como alerta, orientação/reorientação e controle executivo. A orientação/reorientação são requeridas quando estímulos ocorrem fora do foco de atenção presente. Na revisão, constatou-se que esta função é realizada por uma rede lateralizada para o córtex temporo-parietal e para o giro frontal inferior direito. A função foi denominada também de alternância e inclui a manipulação da atenção, enquanto o indivíduo focaliza em uma ou outra tarefa. Nigg e colaboradores (1997) propuseram que o sistema, neste caso, falha em desengajar a atenção de um determinado estímulo, o que é refletido por um tempo de reação (TR) aumentado, para inibir sinais que são colocados como alvos. 
As falhas relacionadas aos desempenhos da atenção, em tarefas que envolvem atenção seletiva, dividida ou sustentada parecem melhor compreendidas quando se considera que sua origem está relacionada a falhas no funcionamento da memória operacional, uma das funções executivas. Embora o nome transtorno de atenção possa indicar um problema atencional exclusivo, considerá-lo como um processo de alteração da memória operacional não parece estranho, principalmente quando se observa a relação íntima entre memória e atenção tanto a partir de modelos cognitivos (DIAMOND, 2005; HELENE e XAVIER, 2003) quanto de neuroimagem (ARNSTEN, 2006; CASEY e colaboradores, 2001; LABAR e colaboradores, 1999; VALERA e colaboradores, 2005). Prejuízos atencionais e de funções executivas são considerados como eixos centrais do TDAH (SEIDMAN e colaboradores, 2005; BARKLEY, 1997).

DUSCHENE e MATTOS (1997) propuseram uma bateria de testes computadorizados para avaliar a atenção em crianças e adolescentes, denominado Teste de Atenção Visual (TAVIS) que vem sendo considerado promissor na avaliação de crianças com TDAH (ver Cruz e colaboradores, 2002).

Essa bateria inclui três tarefas distintas nas quais se avalia tanto os aspectos de atenção seletiva, dividida e sustentada, como os erros de omissão, ação e o tempo de reação. O instrumento foi desenhado para através de tarefas com características atrativas, avaliar o desempenho de indivíduos nas provas em relação à medida de tempo de reação, recurso bastante aceito para avaliação de dificuldades atencionais. A bateria inclui ainda escores de a) erros de omissão, que expressam falhas na manutenção da concentração, com respostas pouco eficazes; e b) erros de ação, que estão associados ao componente de impulsividade com respostas inapropriadas (NIGG e CASEY, 2005).

Um fator importante é que instrumentos para avaliação atencional baseados nos escores de tempo de reação e número de omissões e erros de ação, permitem também a observação de erros de estimativa do tempo (TOPLAK e colaboradores, 2003), uma característica relativamente comum em indivíduos portadores do TDAH (FOLEY NICPON e colaboradores, 2004; KERNS e PRICE, 2001).

Coutinho, Bastos e Mattos (2006a) apresentaram a normatização da terceira versão do teste de atenção visual (TAVIS-III) e uma discussão sobre o valor preditivo 
deste para o TDAH. Os resultados mostraram uma sensibilidade de $84,0 \%$ dos três índices da bateria, incluindo tempo de reação, erros de omissão, e erros de ação, e uma especificidade de $99,2 \%$, numa prevalência de $13,0 \%$ de diagnóstico na população de crianças e adolescentes. Após uma correção da prevalência para $5,0 \%$, que é um índice mais aceito, a sensibilidade foi de $84,7 \%$ e a especificidade foi de $87,5 \%$. Mattos e colaboradores (2006) sugeriram que, embora os testes neuropsicológicos não sejam suficientes ou necessários para o diagnóstico do TDAH, são importantes para delinear um perfil cognitivo e contribuir para um diagnóstico clínico.

Brocki e Bohlin (2004) revisando analiticamente a teoria de Barkley (BARKLEY e colaboradores, 2001) sobre memória operacional e função inibitória, caracterizaram-nas como componentes de funções executivas. Esses autores propuseram, com base em testes neuropsicológicos, a existência de três fatores centrais no surgimento do TDAH: 1) desatenção, resultando em erros de omissão, TR lento e variável no CPT; 2) falha na memória operacional, resultando em erros de reconstituição, incluindo dígitos em ordem invertida, fluência verbal, e tarefa de uso de objetos; 3) inibição, resultando em erros de ação e escores de respostas na CPT. Brock e Bohlin (2004) interpretaram que Barkley e colaboradores (2001) associaram o TDAH aos problemas de memória operacional e de função inibitória, mas estes deveriam ser compreendidos à luz da de dificuldades de regulação e motivação (BROCKI e BOHLIN, 2004; DIAMOND, 2005). Esta hipótese encontra respaldo na característica temporal da CPT. Por ser uma tarefa de tempo longo, a mesma poderia resultar em uma redução do desempenho atencional, pois haveria uma perda motivacional e de regulação ao longo da tarefa.

Levin e colaboradores (1991), comparando crianças com TDAH entre 7-8 anos e 9-12 anos, verificaram que ocorreu redução progressiva em erros de ação e omissões com o aumento da idade; além disso, há uma tendência à estabilização a partir da adolescência (13-15 anos). Williams e colaboradores (1999) observaram que em pessoas com TDAH há uma melhora no tempo de reação para uma resposta impulsiva quando comparou crianças (6-8 anos) a pré-adolescente (9-12 anos). Eles verificaram também que este tempo de reação tende a se estabilizar, poir não encontraram alterações adicionais em jovens adultos (18-29 anos) e idosos (60-81 anos). Adicionalmente, a trajetória da capacidade de fluência verbal ao longo do 
desenvolvimento, que reflete o conceito de reconstituição no modelo de Barkley e caracteriza uma função que continua o desenvolvimento na adolescência, tende também a se estabilizar durante o curso de vida, com decremento apenas em idosos (Levin e colaboradores, 1991).

Hale e colaboradores (1997) compararam o desenvolvimento da memória operacional, por meio da avaliação do desempenho de grupos de crianças entre 8 e 10 anos e adolescentes de 19 anos com TDAH, numa tarefa verbal que consistia em lembrar uma série de dígitos e uma tarefa visuo-espacial, que consistia em lembrar a localização de um $\mathbf{X}$ em uma matriz. As tarefas eram concomitantes, sendo uma primária e a outra secundária. Houve uma relação linear entre idade e extensão da memória operacional, com o grupo de 19 anos exibindo desempenho melhor que o grupo com 10 anos, e este último melhor que o de 8 anos. Os resultados deste estudo parecem encontram suporte na hipótese de que o desenvolvimento dos lobos frontais é fundamental para a emergência de funções como resistência à interferência e que atrasos no desenvolvimento destas habilidades podem prejudicar as funções executivas (ROHDE \& HALPERN, 2004). A trajetória neuroevolutiva de aumento dos volumes intracerebrais de criancas com TDAH segue um curso paralelo de crianças sem o transtorno, porém com volumes significativamente menores (CASTELLANOS e colaboradores, 2002). Estas evidências sugerem que as diferenças encontradas no estudo de Hale e colaboradores (1997) possam estar associadas ao desenvolvimento cortical.

Esse tipo de evidência de diferenças de desempenho cognitivo ao longo do desenvolvimento, indica a necessidade de estudos envolvendo grupos homogêneos, nos diferentes estágios do desenvolvimento (SCHMITZ e colaboradores, 2002), para uma identificação precisa das capacidades cognitivas em cada estágio. A identificação dessas diferenças, especificamente em relação às funções executivas, parece ser crucial. Teorias sobre funções executivas, como a proposta por Barkley (ano), permitem derivar uma variedade de predições comportamentais (VER FOLEY e colaboradores, 2004) e que parecem se aplicar aos diferentes estágios do desenvolvimento.

No desenvolvimento normal é conhecido o fato de que os três componentes da memória operacional (alça fonológica, alça vísuo-espacial e central executiva) se 
tornam progressivamente mais eficientes. Mello e Xavier (2005) reportaram a ocorrência de ensaio sub-vocal a partir dos quatro anos de idade, em tarefas de recordação livre de palavras e em lista de figuras. Esse recurso tende a ser utilizado no repertório de crianças a partir dos 7 anos de idade, como estratégia de memória operacional. A partir dos seis anos observa-se aprendizado de critérios semânticos que passam a ser mais relevantes. As habilidades estratégicas de aquisição e recordação melhoram continuamente até atingir um funcionamento típico do adulto, por volta dos 12 anos de idade.

Há um número limitado de pesquisas sobre os efeitos da idade nas funções neuropsicológicas no TDAH (SEIDMAN e colaboradores, 2005), sendo a maioria concentrada nos efeitos na idade adulta (HERVEY e colaboradores, 2004) e com adolescentes ainda abaixo dos 13 anos de idade, ou seja, na pré-adolescência. Poderse-ia sugerir que características referentes às mudanças e variações do humor, típicas do período, poderiam funcionar como variáveis que interferem nestas condições.

Seidman e colaboradores (1997) avaliaram o desempenho neuropsicológico de meninos, com e sem TDAH, em provas de funções executivas, como a bateria Stroop e o Wisconsin Card Sorting Test (WCST). Os grupos com idade superior a 15 anos tiveram um desempenho melhor daqueles com menor idade, mas não houve uma interação entre os fatores grupo e idade. Seidman e colaboradores (2005) verificaram o desempenho de dois grupos com TDAH, divididos nas idades entre 9-12 e 13-17 anos, usando um conjunto de medidas neuropsicológicas. Estas tarefas envolviam planejamento e organização com o uso do testes da Figura Complexa de Rey (ReyOsterrieth Complex Figure-ROCF), CPT auditivo (ACPT), bateria Stroop, WCST e uma medida de aprendizado verbal. Constataram poucas interações entre a idade e o diagnóstico, sugerindo que déficits neuropsicológicos são similares, independente dos grupos avaliados. Os autores argumentaram que estes resultados ratificando as informações na literatura, quais sejam, que no TDAH o volume cerebral não afeta o desempenho neuropsicológico.

Castellanos e colaboradores (2002) encontraram anormalidades estruturais estáveis, entre as idades de 4 a 18 anos para regiões testadas (lobos frontal, parietal, occipital, temporal, cerebelo), com exceção do núcleo caudado. Além disso, os volumes 
da substância cinzenta dos lobos frontal e temporal foram correlacionados, nas medidas de severidade clínicas e relatos dos pais dos portadores do TDAH. Estes resultados parecem corroborar a hipótese relacionada ao TDAH, como um déficit cuja característica principal é a disfunção executiva e que aparentemente segue o curso de desenvolvimento ao longo da vida, incluindo inibição comportamental e memória operacional (HERVEY e colaboradores, 2004).

As funções executivas têm sido avaliadas quanto à caracterização por sexo, incluindo a memória operacional. Há indicações que as meninas poderiam ter mais déficits de FE do que meninos (NIGG, 1999; RUCKLIDGE e TANNOCK, 2001). Contudo, estas afirmações envolvem limitações metodológicas que impedem interpretações conclusivas, sendo ressaltadas: a) amostras pequenas; b) falha de representatividade entre meninos e meninas, para verificar diferenças de desempenho entre os sexos; c) falhas em avaliar participantes adolescentes, com a maioria dos estudos entre 6 e 12 anos; d) um conjunto, relativamente limitado, de medidas de funções executivas; e) dificuldades de controle experimental para comorbidades como transtorno de conduta (TC) ou transtorno desafiante-opositor (TDO) (FARAONE e colaboradores, 2001; SEIDMAN e colaboradores, 2005).

Brocki e Bohlin (2004) avaliando crianças e adolescentes até os 13 anos de idade, encontraram um desempenho em um nível menor no fator velocidade/alerta, com um maior TR e uma tendência para realizar um maior número de omissões, ou seja, não emitir respostas. Sugeriram que os resultados não foram claros, para que meninas tivessem um desenvolvimento atrasado na auto-regulação para resposta às demandas, mas que talvez estas diferenças fossem explicadas por um maior cuidado selecionando de respostas de maior acurácia. Mesmo com um desempenho um pouco pior, meninas parecem ser mais cuidadosas nas respostas cognitivas, resultando, por exemplo, num TR maior para a resposta, quando comparados com meninos. Aparentemente, a presença de níveis similares, entre os déficits executivos em meninas e meninos com TDAH, parece corroborar a idéia de que muitos dos correlatos clínicos e neurobiológicos são similares nos dois sexos (BIEDERMAN e colaboradores, 2002). Quanto às anormalidades cerebrais, Castellanos e colaboradores (2002) demonstram que no TDAH (1) as meninas e os meninos têm menor volume cerebral; (2) eles não 
apresentam diferenças no volume cerebral entre os sexos e (3) há alterações nos lobos ínfero-posteriores do vermis cerebelar.

As evidências de estudos neurobiológicos e cognitivos têm apontado juntamente para alterações das funções executivas em portadores do TDAH, ainda que, como déficit central, a auto-regulação ou controle executivo permaneça como hipótese (BARKLEY, 1997; FUGGETA, 2006). As funções executivas incluem, dentre outras habilidades, àquelas que permitem indivíduos manter um conjunto de recursos, para solução de problemas com objetivo de alcançar alvos futuros, desenvolver e implementar uma aproximação para desempenho numa tarefa que não é habitualmente desempenhada (desenvolvimento de estratégias). Estão ainda relacionadas a inibição, persistência e flexibilidade de ação (BROCKI e BOHLIN, 2004).

As funções executivas exercem um papel em um número de tarefas e habilidades cognitivas diferenciadas, mas, é geralmente aceito que estas são caracterizadas por propriedades comuns: a) exigem atenção; b) consistem de uma série de operações unitárias, porém integradas, embora limitadas pela capacidade de armazenagem de memória de curta duração; c) são facilmente adaptadas e modificadas (FUGGETTA, 2006). A memória operacional é um item importante dentre as funções executivas e pode ser considerada, inclusive, como um problema primário no transtorno do déficit de atenção.

A literatura em torno do TDAH tem sido mais recentemente focada sob diferenças que poderiam existir entre os diferentes subtipos classificados pelo DSM-IV. Os circuitos neurais diferenciados (NIGG e CASEY, 2005) e as diferenças no funcionamento cognitivo têm sido apontados como evidências nesta direção. Schmitz e colaboradores (2002) em Porto Alegre-RS, numa amostra de 30 sujeitos com TDAH, encontraram um desempenho inferior em testes neuropsicológicos de funções executivas, incluindo memória operacional e memória imediata de conteúdo verbal, quando os sujeitos tinham o tipo desatento ou combinado, ou seja, com a presença de sintomas clínicos de desatenção.

No desenvolvimento normal, os três componentes da memória operacional (alça fonológica, alça visuoespacial e central executiva) se tornam progressivamente mais eficientes. Mello e Xavier (2005) reportaram a ocorrência de ensaio subvocal verificado 
a partir dos quatro anos de idade, em tarefas de recordação livre de palavras e em lista de figuras, tendendo a ocorrer no repertório de crianças a partir dos 7 anos de idade, como estratégias de memória operacional. A partir de 6 anos observou-se um aprendizado de critérios semânticos que passam a ser mais relevantes. As habilidades estratégicas de aquisição e recordação melhoram continuamente, até atingir um funcionamento típico do adulto, por volta dos 12 anos de idade.

Diamond (2005) registrou que o problema central da memória operacional presente em indivíduos com o TDAH - é mais complexo para os indivíduos do tipo desatento ou combinado, em comparação ao tipo hiperativo.

Chabildas e colaboradores (2001) verificaram que os indivíduos com TDAH do tipo desatento e combinado tiveram um desempenho inferior, em provas que avaliaram velocidade de processamento e vigilância, mas não encontraram déficits neuropsicológicos no tipo predominantemente hiperativo, quando a variável desatenção era controlada. Considerarm que o prejuízo neuropsicológico central do TDAH estaria associado com os sintomas clínicos de desatenção e não hiperatividade.

Ao tempo que evoluem dissociações duplas neuropsicológicas entre os subtipos do TDAH, outras funções cognitivas associadas, dependentes ou interativas com funções executivas têm sido alvo mais recentemente de investigações. Na seqüência serão abordados os processos de memória e de suas possíveis alterações no TDAH, sendo enfatizada a memória de longa duração.

\subsection{Memória e suas disfunções relacionadas ao TDAH}

Definições sobre o conceito de memória parecem variar em torno da idéia de que "é o meio pelo qual você recorre às suas experiências passadas a fim de usar essa informação no presente" (STERNBERG, 2000). Helene e Xavier (2003) reportaram que a memória corresponde ao processo pelo qual experiências anteriores levam à alteração do comportamento.

Do ponto de vista do processo envolvido, Robert Crowder, um dos precursores da psicologia cognitiva definiu, de acordo com Sternberg (2000) a memória como "mecanismos dinâmicos associados à retenção e à recuperação da informação sobre a 
experiência passada". Aparentemente, estas definições têm em comum como fonte às operações de memória: a) codificação, onde dados sensoriais numa forma de representação mental; b) armazenamento, onde há a conservação da informação codificada; c) recuperação, onde se extrai a informação armazenada. Freqüentemente, estes estágios são considerados como seqüenciais, onde primeiramente há uma entrada, conservação e recordação da informação, embora, estes processos parecem agir de forma recíproca e interdependente.

Um processo importante refere-se a forma de armazenamento das informações para recuperação ou evocação de longa duração. Aparentemente, esta informação parece ser basicamente codificada semanticamente, por meio dos significados das palavras.

Bousfield (1953) realizou um procedimento de memória intencional e conseguiu que as pessoas aprendessem uma lista de 60 palavras - constando 15 em quatro grupos: animais, profissões, plantas e nomes de pessoas. As palavras foram apresentadas em ordem aleatória e os sujeitos evocavam-nas livremente. A hipótese do trabalho sustentava que os indivíduos deveriam lembrar mais palavras sucessivas da mesma categoria. Efetivamente constatou-se que os indivíduos lembravam mais palavras quando agrupadas em categorias do que em ordem aleatória.

Há evidências da existência de outros processos cooperativos para codificação da memória de longo prazo. Frost (1972) verificou padrões de seleção para codificação visual, dependentes da posição, quando estímulos semanticamente relacionados foram apresentados aos sujeitos. Os participantes do experimento evocaram informações relacionando-as semanticamente, mas também visualmente, de acordo com a disposição dos estímulos visuais, que eram colocados em quatro posições diferentes (horizontal, vertical, oblíquo para a esquerda e oblíquo para a direita). Foi reportado que provavelmente utiliza-se tanto recursos semânticos quanto proposicionais, para lembrança de estímulos na memória de longa duração (STERNBERG, 2000).

Ainda está em investigação se a codificação para armazenamento na memória de longa duração ocorreria segundo critérios de organização, pelo significado ou pela forma física exata de uma informação. No dia-a-dia se tem uma variedade de recordações que parecem seguir critérios de organização semântica, o que explica, 
inclusive, a perda de alguns detalhes na codificação. Há também demandas para arquivar lembranças literais, como àquelas utilizadas na recordação de uma fala, numa peça de teatro ou ainda na recordação específica de alguns conteúdos em avaliações escolares (HUFFMAN e colaboradores, 2003).

As evidências de neuroimagem têm demonstrado diferentes vias neurais envolvida noo processo codificação. Sommer e colaboradores (2005) verificaram a memória para objetos e a localização no espaço, utilizando o procedimento que incluiu um mapeamento funcional da atividade cerebral. Eles demonstraram o envolvimento do córtex para-hipocampal $(\mathrm{CPH})$ bilateral na codificação de objetos associados à localização, enquanto atividade no $\mathrm{CPH}$ anterior esquerdo e do lobo temporal medial, estaria associada com a localização somente.

Keri (2003) reportou o envolvimento de diferentes áreas cerebrais envolvidas com o aprendizado em categorias. O córtex pré-frontal parece influenciar a representação categorial no córtex sensorial via controle "de cima para baixo", ou seja, atuando antecipadamente a partir de experiências acumuladas. Ao mesmo tempo, o córtex órbito-frontal e o estriado ventral parecem ser cruciais, para as situações que envolvem associações de reforço, que seguem o aprendizado em categorias. Estes estudos recentes corroboram as hipóteses de que diferentes tipos de codificação estejam envolvidos para memória de longa duração, assim como outras publicações recentes, indicativas de diferentes estruturas e circuitos envolvidos (ADDIS e McANDREWS, 2006; KANE e ENGLE, 2000; SUZUKI e colaboradores, 2005; WAGNER e colaboradores, 2005).

É provável que a perda de alguns elementos durante a codificação para a memória de longa duração seja dependente dos processos de atenção e da seleção dos estímulos relevantes para registro. Helene e Xavier (2003) enfatizaram o debate sobre a ocorrência da seleção de estímulos em diversas etapas, a saber: 1) nos estágios iniciais do processamento atencional, antes do ingresso da informação; 2) no próprio sistema de capacidade limitada de atenção, através das escolhas que influenciarão a resposta, destacando a existência de dois domínios de processamento.

Estas hipóteses sugerem que entram no sistema apenas as informações efetivamente relevantes para o indivíduo, incluindo informações relevantes retidas na 
memória anteriormente, que receberam treino específico ou que têm um nível de expectativa para ocorrer.

Baddeley (2000) sugeriu a existência de um componente denominado retentor episódico (episodic buffer) em seu modelo de memória operacional, que corresponderia a um sistema de capacidade limitada no qual a informação evocada da memória de longa duração (MLD) tornar-se-ia consciente (HELENE e XAVIER, 2003).

Apesar da existência de um processo consciente para a recordação, nem sempre o estímulo que contribui para uma resposta torna-se consciente. Exemplos envolvem a memória não-declarativa (habituação), onde o sujeito parece prestar pouca atenção sobre o estímulo, mesmo que seu desempenho torne-se progressivamente melhor, principalmente quando passa a haver consolidação do aprendizado (STERNBERG, 2000).

A interação destes elementos de atenção, discutidos no Capítulo 2, com o funcionamento da MLD, parece contribuir extensivamente para o bom desempenho da memória. Ainda, prejuízos nos sistemas de processamento atencional podem resultar no processamento de memória também prejudicado, ao tempo que o registro, através do treinamento prévio da rede nervosa parece interferir com o funcionamento dos processos de atenção (BADDELEY, 2000; HELENE e XAVIER, 2003).

Tem sido proposto que alguns tipos de déficit de memória podem ser característicos de crianças com TDA sem hiperatividade. O modelo de Barkley (1997) constou que quatro funções executivas devem estar associadas com inibição comportamental. No modelo especifica-se que a memória operacional pode estar prejudicada, particularmente, porque é uma função da habilidade do indivíduo para prolongar a representação mental de eventos. Enquanto a memória operacional tem sido alvo de investigação em uma série de estudos sobre TDAH, a maior parte dos mesmos, enfoca sobre a memória operacional como parte da investigação das funções executivas (BROCKI e BOHLIN, 2004; DIAMOND, 2005; FUGGETTA, 2006; SEIDMAN e colaboradores, 2001; 2006).

Diamond (2005) considerou a memória operacional como o componente central do TDA ou TDAH do subtipo desatento, mas não do subtipo hiperativo. Por outro lado, problemas de memória no TDAH são descritos por portadores dos três subtipos, ainda 
que as definições de distúrbios de memória no TDAH necessitem de serem investigadas. Existem dados insuficientes para dar suporte à noção de que algum tipo específico de déficit de memória seja uma característica central no TDAH (KAPLAN e colaboradores, 1998).

Do ponto de vista clínico, a categoria "problemas de memória" parece ser uma queixa comum de portadores adultos e de pais de crianças e adolescentes com TDAH, chegando a fazer parte de maneira inespecífica da avaliação do TDAH (BROWN, 1996).

Efetivamente, apesar das evidências clínicas favoráveis à presença de déficits de memória no TDAH, a literatura que contrasta com estas afirmações questiona o déficit de memória como uma característica central no transtorno. Ott e Lyman (1993) não encontraram déficits, quando buscaram um tipo de memória que se atribui ser automática e com pouco esforço (localização espacial). As crianças com TDAH tiveram dificuldades ao serem testadas para evocação livre, com menos itens evocados a partir de um livro de figuras, o que refletiu um esforço maior para esta tarefa. É possível que estas alterações tenham sido devidas a outras dificuldades como alterações de memória operacional verbal. Estão presentes em indivíduos com TDAH, não por um déficit de memória verbal para a evocação propriamente dito. Investigações sobre o tipo de processamento que interfere com estas funções continuam sendo conduzidas, apontando para uma multiplicidade de causas para este desempenho inferior na recordação dos itens (KAPLAN e colaboradores, 1998).

Discriminação de desempenho entre indivíduos com TDAH e distúrbios de aprendizagem (DA) parece ser crucial para verificação de déficits neuropsicológicos específicos em funções mnésicas. Korkman e Pesonen (1994) relataram dissociações duplas nos perfis neuropsicológicos de crianças com TDAH, Distúrbio de Aprendizagem (DA) e TDAH+DA. As crianças com TDAH somente tiverem mais dificuldades em testes que avaliaram inibição e controle; as crianças com DA tiveram mais dificuldades com análise auditiva, span de dígitos e recontar histórias; entretanto, todos os grupos tiveram dificuldades com a recuperação de nomes. Estes dados sugerem no mínimo a caracterização de déficits verbais mnésicos para indivíduos com TDAH. 
Seidman e colaboradores (2006) avaliaram uma amostra de quatro grupos constituídos por meninas: TDAH medicadas, TDAH não-medicadas, TDAH +DA e grupo controle sem TDAH ou DA. Eles avaliaram o desempenho em uma série de testes neuropsicológicos, incluindo um instrumento de aprendizagem e memória, o Wide Range Achievement Test of Memory and Learning (WRAML). Inicialmente, constataram que as participantes medicadas para o transtorno tiveram um desempenho superior àquelas não medicadas, nos escores de evocação do teste, mas, inferior ao grupo controle, sem diagnóstico de TDAH.

Os resultados não diferiram de comparações, em termos de desempenho de meninos nas mesmas condições, em um estudo realizado anteriormente. Adicionalmente, as meninas que tinha o TDAH + DA apresentaram desempenho inferior no WRAML, bem como, em outras medidas da investigação. Apresentaram erros de perseveração no Wisconsin Card Sortint Test (WCST), evocação na Figura Complexa de Rey (ROCFT) e nomeação das cores na bateria Stroop. Os autores sugeriram que a comorbidade de DA aumentou os prejuízos nas funções executivas no TDAH e de que isto não é dependente do sexo.

Instrumentos como o WRAML são confiáveis para verificação de funções de atenção e memória. Em investigações com instrumentos similares diferenças entre estas funções para crianças com TDAH têm sido descritas. Enquanto crianças com dislexia (DA) são referidas como apresentando déficits de memória mais generalizados, àquelas com TDAH parecem apresentar mais erros em tarefas de memória que requerem estratégias organizadas, volitivas e treinadas (DOUGLAS e BENEZRA, 1990). Os erros pareceriam ser neste caso, mais associado então ao uso de estratégias de agrupamento das informações a serem lembradas, mais do que propriamente como um erro puro de memória.

O estudo desenvolvido por Kaplan e colaboradores (1998) mostrou-se bastante negativo para a hipótese de que indivíduos com TDAH apresentem déficit de memória de longa duração. As perguntas principais dos autores foram: a) crianças com TDAH sem comorbidades esquecem conteúdo aprendido? A hipótese era de que não haveria esse tipo de esquecimento, mas que a evocação poderia refletir mais uma disfunção executiva ou desatenção per se; b) crianças com DA poderiam ter prejuízos na memória 
verbal (perda de informação) quando comparadas com crianças com TDAH. Os autores utilizaram a prova WRAML para avaliar a memória de crianças (idade: 12,4 anos), com quatro provas que envolveriam um teste de evocação tardia para história, aprendizado verbal, aprendizado visual e som-símbolo. Além disso, foram utilizados os escores denominados saving scores, que representaram o resultado da evocação tardia dividida pela tentativa inicial, indicando a taxa de esquecimento ao longo do tempo.

Os escores foram computados para Memória Verbal, Memória Visual, índice de Aprendizagem e índice de Memória Geral. Em todos eles os grupos com TDAH puro, DA e TDAH + DA, obtiveram desempenho inferior ao grupo controle. Entretanto, nos índicess saving scores, o grupo de TDAH teve um desempenho similar ao do grupo controle, enquanto os grupos DA e TDAH + DA apresentaram índices inferiores ao do grupo controle na memória de história, evidenciando que indivíduos com TDAH, não teriam esquecimento rápido da informação e codificariam informação na memória de longa-duração.

A memória de histórias foi à única que o grupo com TDAH teve um desempenho melhor do que os grupos TDAH + DA e DA. Segundo os referidos autores, diferentemente dos outros três testes utilizados que permitiam 4 repetições para aprendizagem, a memória de história revelou que as crianças com TDAH não têm déficit de memória verbal, como uma característica obrigatória e que se aprenderem uma lista com repetições, podem ter um desempenho similar ao de indivíduos sem TDAH.

Os resultados do estudo não foram suficientes para caracterizar os transtornos de memória como presentes no TDA sem hiperatividade, mas sim, de caracterizá-los como provavelmente dependentes e presentes na arena das funções executivas, associadas a inibição comportamental, no mínimo, nos casos do TDAH sem comorbidades. Para o grupo TDAH+DA os déficits de memória verbal foram apresentando como sugestivos de falhas no processamento de memória e na análise fonológica (KAPLAN e colaboradores, 1998).

Cornoldi e colaboradores (1999) constataram que indivíduos com TDAH têm uma ampla variedade de déficits cognitivos, incluindo déficits de memória. O’Neil e Douglas (1991) consideraram que os déficits apresentados pelos sujeitos com TDAH, em 
memória para histórias eSTARIAM relacionados mais com desempenho inferior no processamento executivo, que no conhecimento de uma estratégia para recordação. Apesar do controle atencional, discutido no Capítulo 2, apontar que as funções de controle atencional estejam envolvidas com funções mnésicas, apresentam poucos estudos envolvendo a avaliação de desempenho em tarefas de memória estratégica, ou seja, que requerem a avaliação de estratégias de memória estratégica.

Vários fatores têm sido vinculados a déficits de memória no TDAH, aparentemente devido às falhas na memória estratégica, dependente de um nível metacognitivo inferior. A metacognição refere-se ao conhecimento do próprio conhecimento, uma capacidade que permeia uma série de funções cognitivas tais como memória, leitura e compreensão de textos (RIBEIRO, 2003). De fato, o uso de estratégias organizacionais, como agrupamento, requer uma série de processos metacognitivos, tais como: a) o conhecimento semântico e a inferência de relação entre estímulos; b) o conhecimento acerca das vantagens do uso de estratégias de agrupamento; c) planejamento de comportamentos estratégicos; d) monitoramento; e) inibição de respostas incorretas anteriores em tentativas sucessivas; f) conhecimento sobre a organização e estrutura da lista durante a recordação (CORNOLDI e colaboradores, 1999).

Para testar se crianças com TDAH teriam dificuldades de memória estratégica relacionadas as falhas nas FE's ou dependentes de conhecimento semântico, Cornoldi e colaboradores (1999) realizaram três experimentos. No experimento 1, utilizaram quatro matrizes de 16 figuras representando figuras nomeáveis e objetos familiares, constando dois grupos, oito categorizáveis com dois grupos (animais e roupas) e oito não-categorizáveis, sendo apresentadas em uma ordem alternada. A segunda matriz apresentou os mesmos estímulos com arranjo espacial diferente do primeiro. $\mathrm{Na}$ terceira matriz, organizada como a primeira, $50 \%$ dos elementos eram novos enquanto a outra metade fora apresentada anteriormente. $\mathrm{Na}$ quarta matriz os elementos eram os mesmos da terceira, organizados espacialmente de maneira diferente.

As matrizes foram apresentadas, em cada minuto, sucessivamente, com evocação em ordem livre, após a apresentação dos elementos visualizados. Para computação dos dados o procedimento considerou agrupamento apenas quando dois 
elementos eram apresentados sucessivamente (saia e vestido), ou seja, por critério de adjacência, que foi mais elevada para o grupo controle do que para o grupo com TDAH.

Houve adicionalmente um menor número de evocações corretas no grupo TDAH. O grupo com TDAH teve um maior número de intrusões nas primeira e segunda matrizes. O grupo controle teve um maior número de intrusões nas terceira e quarta matrizes.. No primeiro experimento foi aplicado também o questionário de metamemória de Belmont e Borkowsky (1988). No questionário de metamemória não houve diferenças entre os grupos. O questionário versa sobre o uso consciente de estratégias para armazenamento e recordação. Os autores sugerem que a interpretação dos dados deva ser observada a partir da existência, em indivíduos com TDAH, de falhas no uso de estratégias de memória de agrupamento. As intrusões também sugeriram um uso ineficiente de memória estratégica. Por outro lado, os autores sugeriram que estas não decorram aos erros na metamemória.

Num segundo experimento, os autores exploraram como a metacognição poderia interferir com o desempenho na tarefa de memória. Os sujeitos foram diretamente orientados a usar estratégias de agrupamento (componente de conhecimento da metacognição) e auxiliados a fazer a aplicá-las (componente regulatório-executivo). $\mathrm{O}$ questionário de metamemória aplicado voltou a ser aplicado em novo grupo de pacientes e o de memória (matrizes), mas com uma organização de forma a aumentar a possibilidade de intrusões, com itens na segunda e quarta matrizes similares de uma das mesmas categorias da primeira e segunda matrizes.

Adicionalmente outras quatro matrizes foram aplicadas usando as mesmas regras para esse novo teste. Os sujeitos foram testados em duas sessões. Na primeira foram apresentadas quatro matrizes similares a do experimento 1 , sendo que nesta sessão também houve a aplicação do questionário. Na segunda sessão, o novo teste foi aplicado da matriz 1 a 5 ; na sexta matriz uma das investigadoras apresentava uma ajuda referente a como classificar em "família", as figuras apresentadas e tinha 40 segundos adicionais para memorizar os itens categorizáveis.

No questionário de metamemória todos os indivíduos com TDAH receberam uma pontuação menor do que indivíduos do grupo controle, mesmo que tenha sido, entre os 5 itens, significativa a diferença apenas para as perguntas 1 e 5 . Diferenças foram 
encontradas nas tentativas 1 a 4, com distribuição similar a do primeiro teste, mas mais sensível a intrusões, que também foram em número maior. Quando auxiliadas (sessão 2, tentativas 5 a 8) com estratégias de categorização, não houve diferenças entre os grupos, nem no número de intrusões, nem no número de itens pelo critério de adjacência, que melhorou no grupo TDAH após a inclusão do auxílio (tentativas 6 a 8). Qual a importância destes resultados? Aparentemente as crianças com TDAH são sensíveis ao aprendizado de estratégias. Os autores sugerem que apesar dos resultados no questionário de metamemória terem sido menores para o grupo TDAH, não houve correlação com o desempenho em memória.

Permaneceu ainda a questão qual seria o conhecimento ou o controle metacognitivo que responderia pela eliminação após o aprendizado, do déficit de memória estratégica no grupo com TDAH. De fato, na clínica observa-se o relato dos pacientes, referentes as dificuldades de memória e categorização, entretanto sem que estes mesmo consigam identificar onde provavelmente estaria a falha: se na aquisição e lembrança da estratégia cognitiva ou se no controle de seu uso. Para responder a esta questão um terceiro experimento foi conduzido, utilizando dica de conhecimento sobre a estratégia, mas sem assistência específica, como no experimento 2 .

O uso de um experimento de planejamento, a Torre de Londres (LEVIN e colaboradores, 1991) evidenciou um baixo desempenho no grupo TDAH e com uma relação de ser o melhor preditivo para o baixo desempenho no teste de memória. Esta relação cooperou para que se sugerisse que as dificuldades observadas de categorização ou agrupamento pudessem ser dependentes de problemas no controle executivo e não no conhecimento metacognitivo da memória. Juntos, estes dados sugerem que o componente metacognitivo, no papel de regulador, possa ser o responsável pelas falhas de memória nos sujeitos com TDAH, ao passo que o componente de metamemória não tenha sido evidenciado como associado às falhas no teste de memória.

Um fator neste estudo é que os achados específicos tanto relacionados às estratégias utilizadas como do desempenho direto da memória foram considerados para o grupo TDAH sem divisão por subtipos. Apenas no terceiro experimento utilizou-se um critério de baixo desempenho num teste atencional como critério de inclusão para o 
grupo de desatenção. Estudos de memória operacional têm indicado maior comprometimento nos sujeitos com tipo combinado ou desatento do transtorno (DIAMOND, 2005; SCHMITZ e colaboradores, 2002). A maioria dos estudos sobre TDAH e memória se concentra na memória verbal, que parece ser prioritariamente alterada e sensível às disfunções de memória operacional e de curto prazo (KAPLAN e colaboradores, 2005; KOURAKIS e colaboradores, 2004; ROSENTHAL e colaboradores, 2005). Reynolds (1997) sugeriu que as provas de span de dígitos e span de dígitos invertidos das escalas Wechsler (WESCHELER e FIGUEIREDO, 2002) possam funcionar como provas distintas para diferentes funções no TDAH.

Tem sido sugerido que a prova de dígitos na ordem direta (DD), seja uma tarefa de memória auditiva de curta-duração, enquanto a prova de dígitos invertidos (DI) seja mais sensível para detectar déficits de memória operacional (HALE e colaboradores, 2002). Rosenthal e colaboradores (2005) constataram que DD e DI juntos não serviram como preditivos para diagnóstico de dificuldades atencionais. Porém quando DI foi analisado separadamente, portadores do TDAH do tipo combinado tiveram um desempenho pior em relação aos desatentos, sendo uma evidência importante do funcionamento cognitivo e dá suporte a proposição de Barkley (1997), de que os diferentes subtipos do TDAH apresentam déficits diferenciados.

Faraone e colaboradores (1998) encontraram diferenças significativas no funcionamento neuropsicológico em crianças em adolescentes para os subtipos desatento e combinado. Entretanto, diferenças entre os 3 subtipos não foram evidenciadas.

Chabildas e colaboradores (2004) não encontraram diferenças no perfil neuropsicológico entre os diferentes subtipos, mesmo entre o tipo desatento e combinado. Schmitz e colaboradores (2002) sugeriram, a partir de evidências de outros estudos e de uma amostra brasileira, que o subtipo hiperativo não apresentou problemas cognitivos significativos. Por outro lado, os autores consideraram que o tamanho da amostra e fatores relacionados à possível presença de erros tipo I possam ter interferido nos resultados.

Øie e Rund (1999) compararam adolescentes com diagnóstico de esquizofrenia e adolescentes com TDAH, numa ampla bateria de testes e verificaram com um teste 
de memória visual, que o desempenho dos indivíduos com esquizofrenia foi pior dos que tinham TDAH. Ambos os grupos tiveram um desempenho pior do que o grupo controle. Gitten e colaboradores (2006) realizaram um experimento elegante de aprendizado associativo condicional de informação visual sobre objetos e localização espacial. Por tratar-se de uma prova de aprendizagem, foi solicitado aos participantes a evocação imediata dos estímulos apresentados.

Numa tela de computador uma figura de um menino aparecia e podia ser ligada a determinados alimentos. Se fossem pareados corretamente o participante recebia um sinal de bom desempenho. Logo a seguir, os indivíduos deveriam lembrar quais os alimentos pareados que apareciam na tela do computador. Numa segunda tarefa, os sujeitos deveriam desempenhar uma escolha numa tarefa de aprendizado associativo condicional espacial: foi necessário selecionar, com o uso de um mouse, onde objetos deveriam estar localizados. Utilizou-se uma tarefa bastante agradável para crianças, que consistia em encontrar uma borboleta que corresponderia, pela localização, à lagarta que tinha sido anteriormente apresentada.

A imagem da lagarta ficava disponibilizada na porção superior da tela do computador. Os indivíduos com TDAH ( $n=12$; idade: 10, 7) apresentaram um desempenho similar aos do grupo controle na tarefa de objetos, mas inferior na tarefa que envolveu o componente espacial. Os autores sugeriram que o TDAH não produziu um déficit de aprendizado associativo condicional geral, mas que o déficit apareceu quando o uso de processos estratégicos foi necessário, para o bom desempenho na tarefa espacial. Uma explicação adicional oferecida pelos autores é que parece que os portadores do TDAH têm mais dificuldades para manter a organização. É possível então, que haja falhas nos processos de controle, que facilitariam o bom desempenho ao longo de tarefas extensas.

Gibney e colaboradores (2002) utilizaram uma escala cognitiva americana, Differential Ability Scales (DAS) a fim de verificar sua validade para a medida de funcionamento neurocognitivo no TDAH. Entre as provas aplicadas, a de evocação de desenhos, uma prova de memória visual mostrou um desempenho abaixo do normal na população geral. Os erros nessa prova parecem estar presentes também em outras desordens neurológicas. 
Slomine e colaboradores (2005) examinaram funções cognitivas de atenção, aprendizagem e memória em crianças com traumatismo cranioencefálico (TCE) com quadro pré-mórbido de TDAH (P-TDAH) e TDAH secundário (S-TDAH) ao TCE. Utilizando uma medida bastante conhecida de memória verbal, o Califórnia Verbal Learning Test (CVLT) eles verificaram um desempenho inferior de aprendizagem (Tentativas 1-5) de uma lista de palavras, evocação livre de curta-duração (MCD), evocação livre com dicas de memória de longa-duração (MLD), evocação com dicas de MLD e discriminação (um teste de reconhecimento). Diferenças na evocação com dicas de MCD foram encontradas para o S-TDAH e TCE. Os grupos P-TDAH e S-TDAH tiveram baixo desempenho nas tarefas de evocação com dicas de MCD, evocação livre e com dicas de MLD, e discriminação.

Nas tarefas de memória, o grupo com S-TDAH teve o pior desempenho. Os autores argumentaram que o racional pareceu ser a provável interação neural das vias alteradas, devido ao TCE. O grupo P-TDAH apresentou um desempenho melhor que o S-TDAH, mas abaixo do grupo TCE. Uma distinção de quais as vias neurais que foram alteradas exclusivamente nestes casos torna-se difícil. Assim, os autores sugeriram que os resultados devam ser considerados preliminarmente, mas indicam que dificuldades relacionadas à aprendizagem e memória parecem ser efetivamente características de portadores do TDAH. Tipicamente, estas alterações parecem contribuir, dentre outras coisas para o baixo desempenho escolar (MDE) de alunos com TDAH e contribuem para problemas emocionais e comportamentais relacionados ao transtorno (Pastura e colaboradores, 2005).

O número reduzido de trabalhos com memória e aprendizagem em TDAH parece ser um fator que gera surpresa (GITTEN e colaboradores, 2006). Talvez o fator principal seja que déficits de memória, como aqueles relacionados ao aprendizado associativo pareado, sejam mais dependentes de funções de memória e de estruturas do lobo temporal mesial. Em contraste, tarefas de aprendizado associativo condicionado, que parecem depender de vias frontoestriatais, envolvidas com estratégias categoriais, dificuldades para o sujeitos com TDAH parecem ser mais proeminentes.

Avaliando funções de memória em grupos com TDAH do tipo combinado, TDAH com distúrbio de aprendizagem (DA) e de lesão temporal mesial (LTM), Narbona e 
Crespo-Eguílaz (2005) encontraram diferenças na aprendizagem e memória verbal de sujeitos com LTM $(n=8)$ em relação aos sujeitos com TDAH e TDAH+DA $(n=17)$.

No teste de memória visual, utilizando o teste da Figura Complexa de Rey (ROCFT), os resultados foram superiores para o grupo com TDAH e TDAH+DA em relação ao grupo LTM, mas sem diferença significante. Não fica clara a média de idade dos sujeitos avaliados, uma vez que diferenças de desempenho parecem ser importantes ao longo do desenvolvimento, em diferentes testes de memória, os quais, utilizam ou não categorização (MELLO e XAVIER, 2005).

Adicionalmente os indivíduos avaliaram sujeitos com TDAH apenas do subtipo combinado. Um terceiro fator é que o estudo, do tipo descritivo não faz comparações do desempenho relacionado a um grupo controle sem a presença de TDAH e não fica claro, se o desempenho no teste ROCFT estaria num nível menor do que aqueles alcançados por crianças sem o TDAH.

Experimentos de memória visual no TDAH, como realizados por Cornoldi e colaboradores (1999), tipicamente envolvem provas de atenção e funções executivas (SEIDMAN e colaboradores, 2006). A análise fatorial das funções executivas (FE) tem sugerido pelo menos quatro fatores envolvidos, quais sejam: inibição de resposta e execução, memória operacional, alternância e controle de interferência (WILLCUTT e colaboradores, 2005).

Aparentemente, o modelo envolvendo déficits de FE tem um alto valor heurístico para a compreensão do TDAH (SERGEANT e colaboradores, 2002). Por outro lado, existe considerável sobreposição de outras funções envolvidas, como certos componentes de aprendizagem e memória, especialmente nos processos que sustentam a codificação e recuperação em portadores do transtorno (PENNINGTON e OZONOFF, 1996).

Tem sido considerado se essas alterações seriam suficientemente robustas para servirem para o diagnóstico diferencial do TDAH (BARKLEY, 1997; SEIDMAN e colaboradores, 2006). Algumas pesquisas sobre a memória de indivíduos portadores do TDAH têm sugerido também que as alterações de codificação, categorização e recordação sejam dependentes de falhas nas funções executivas (CORNOLDI e colaboradores, 1999; PENNINGTON e OZANOFF, 2002). 
A fim de contribuir para uma resposta às perguntas sobre a existência de prejuízos de memória de longa duração no TDAH, esta investigação foi conduzida com as seguintes questões fundamentais:

- Há realmente um déficit de memória de longa duração no TDAH?

- Se existentes, como se caracterizam nos diferentes subtipos?

- A apresentação de informações categorizáveis e não categorizáveis resultam em diferença no desempenho dos portadores de TDAH de predomínio desatento, combinado ou hiperativo?

- A apresentação de estímulos em série ou agrupados interfere com a lembrança em indivíduos portadores do TDAH e nos diferentes subtipos?

Os referidos questionamentos delinearam a elaboração deste experimento e procedimento (Seção 5.2) dirigido a escrutinar o desempenho dos portadores dos três subtipos do TDAH e de participantes sem história do transtorno. A prerrogativa da proposta é contribuir ao conhecimento no TDAH nos diferentes subtipos ao ser avaliado se:

1) existe déficit de memória de longa duração: adotando-se o instrumento com intervalo para evocação igual a vinte minutos e com a inserção de provas que servem como distratores;

2) estratégias de memória, principalmente aquelas relacionadas a organização (MELLO e XAVIER, 2005) estão adequadamente desenvolvidas nos portadores: sendo amostrados adolescentes na faixa etária entre 11 a 14 anos, quando se espera que habilidades estratégicas de aquisição e recordação já estejam bem desenvolvidas (BJORKLUND e DOUGLAS, 1997). Espera-se que aumento da idade ao longo do desenvolvimento em crianças resulte numa maior freqüência de associações taxonômicas entre os estímulos (MELLO, 2003);

3) a apresentação em série ou agrupada de estímulos altera o desempenho de memória de longa e curta duração dos portadores, em relação aos não portadores. No procedimento optou-se por repetir a apresentação em série, observando-se uma curva de aprendizagem, como um dos possíveis efeitos posteriores sobre a memória de longa duração. 
Espera-se que esta investigação acrescente informações úteis sobre a memória e os subtipos do TDAH, favorecendo a compreensão das alterações neuropsicológicas e clínicas existentes conhecidos pelas observações, para contribuição para o diagnóstico e para especificar os prejuízos específicos dos diferentes subtipos, 


\section{OBJETIVOS}

\subsection{Objetivo Geral}

Identificar possíveis alterações neuropsicológicas da memória de longa duração, em participantes escolares e portadores de Transtorno do Déficit de Atenção/Hiperatividade (TDAH), nos três subtipos predominantes de apresentação: desatento, hiperativo e combinado, em etapa específica do desenvolvimento humano, na faixa etária de onze a quatorze anos.

\subsection{Objetivos Específicos}

a) Mensurar possíveis diferenças para os subtipos em tarefas categoriais e não categoriais de memória visual de longa duração.

b) Qualificar possíveis diferenças no desempenho dos indivíduos portadores dos subtipos do TDAH em apresentações seriadas e agrupadas.

c) Avaliar o desempenho de indivíduos em três tipos de funções atencionais, atenção seletiva, dividida e sustentada, caracterizando-as por grupos com os diferentes subtipos do TDAH.

d) Identificar a aprendizagem de estratégias organizacionais de memória, principalmente de categorização semântica, comparando a aquisição entre 11 e 14 anos de idade em indivíduos portadores e não portadores do TDAH.

e) Demarcar diferenças específicas relacionadas ao processo de aprendizagem e sua relação com o desempenho de memória de longa duração. 


\section{MÉTODOS}

\subsection{Caracterização Situacional}

Este trabalho foi desenvolvido na Clínica Discernir situada à Rua Leonor Calmon, 256, na cidade de Salvador, Bahia, localizado no nordeste brasileiro. A amostragem deste trabalho foi constituída de quarenta e quatro pacientes com diagnóstico positivo e formalizado de Transtorno do Déficit de Atenção/Hiperatividade (TDAH), recomendados por quatro profissionais independentes, dois médicos, duas neurologistas e um psiquiatra da infância e da adolescência; uma psicóloga e o próprio investigador, também psicólogo, todos em exercício profissional em prática privada na capital do Estado da Bahia.

Todos os pacientes ou responsáveis foram informados e concordaram em assinar o Termo de Consentimento para uso das informações em trabalho de pesquisa e posterior publicização, sendo preservadas sua integridade e identidade, conforme preconizado, encaminhado previamente e aprovado o desenvolvimento da pesquisa pelo Conselho de Ética do Instituto de Psicologia da Universidade de São Paulo, conforme Modelo e Termos ( Apêndice A; Anexo A).

\subsection{Descrição da Amostra}

\subsubsection{Grupo Caso: Portadores do Transtorno do Déficit de Atenção/Hiperatividade}

O diagnóstico de TDAH dos quarenta e quatro pacientes, 34 meninos, 10 meninas, foi estabelecido através de duas estratégias comuns, previamente recomendadas aos profissionais indicadores, conforme os seguintes critérios: a) apresentação de seis ou mais sintomas de desatenção, hiperatividade ou ambos, de acordo com os critérios estabelecidos na escala Swanson, Nolan and Pelham Questionnaire - SNAP-IV (SWANSON e colaboradores, 1994; Anexo B), baseada no DSM-IV(AMERICAN PSYCHIATRIC ASSOCIATION, 1994).; b) referência e avaliação de outro profissional com concordância sobre o diagnóstico.

Se o participante do grupo TDAH foi avaliado inicialmente pelo pesquisador, procedeu-se o encaminhamento do paciente para o profissional médico (Psiquiatra ou Neurologista) para confirmação diagnóstica. Se encaminhado por outro profissional, o pesquisador realizou os procedimentos diagnósticos, para confirmação ou não do diagnóstico de TDAH. 
Para inclusão no grupo de TDAH os participantes deveriam (a) ter diagnóstico de TDAH do tipo desatento, hiperativo ou combinado; (b) estar livres de comorbidades incluindo psicose, retardo mental, doença neurológica (paralisia cerebral) ou doença física crônica; (c) não ter sintomas de distúrbios da leitura segundo o DSM-IV (AMERICAN PSYCHIATRIC ASSOCIATION, 1994) (d) não fazer uso de medicação psicotrópicas, incluindo estimulantes para o tratamento do TDAH; (e) estar na faixa etária entre 11 anos, 0 mês e 1 dia a 14 anos, 11 meses e 29 dias; (f) estar regularmente matriculado e cursando da $5^{\mathrm{a}}$ a $8^{\mathrm{a}}$ série do ensino fundamental; (g) pelas características de homogeneidade do estudo, estar matriculado em escola da rede de ensino privada; (h) ter assinado por seus pais o termo de consentimento livre e esclarecido e concordarem livremente com os procedimentos da pesquisa. Em função da alta taxa de comorbidade com Transtorno Opositor-Desafiante (TOD) e Transtorno de Conduta (TD), a presença destes transtornos não foi critério de exclusão.

Uma investigação constando cinco procedimentos foi utilizada para selecionar os pacientes/participantes, e são descritos a seguir:

a) encaminhamento para o diagnóstico - foi estabelecido por um dos dois neurologistas pediátricos, psiquiatra da infância e adolescência ou psicólogo, sendo criado para cada indivíduo um banco de dados do diagnóstico, que incluiu questionário e entrevista com os pais e adolescentes para inclusão no grupo TDAH e exclusão de outros diagnósticos;

b) solicitação a cada responsável pelos participantes que completassem um questionário estruturado, conforme Modelo (Apêndice B), incluindo dados das seguintes áreas: a) demográfico e econômico, de acordo com os critérios da Associação Brasileira de Empresas de Pesquisa (ABEP, 2003), variando para facilitação da computação dos dados neste estudo em quatro categorias econômicas: renda familiar de até 5 salários mínimos (1); entre 6 a 10 salários mínimos (2); 11 a 20 salários mínimos (3); e mais de 20 salários mínimos (4). Adicionalmente, seguindo os critérios da ABEP (2003);

c) uma caracterização sócio-econômica familiar, constando uma tabela com bens de consumo; escolaridade parental variando de um a cinco (não alfabetizado/primário incompleto a superior completo); 
d) uma anamnese para caracterizar o diagnóstico, contendo histórico médico, psiquiátrico e escolar; presença de sinais e sintomas de distúrbios de aprendizagem (dislexia, discalculia e disgrafia) e queixas atuais;

e) critérios do DSM-IV (AMERICAN, 1994) para sintomas do TDAH de acordo com escala SNAP-IV (SWANSON e colaboradores, 1994), na versão validada para o Brasil pelo Grupo de Estudos em Déficit de Atenção da Universidade Federal do Rio de Janeiro (UFRJ), por Mattos e colaboradores (2006b).

Embasados nos critérios do DSM-IV, os diagnósticos foram estabelecidos para a presença de TDAH, de acordo com os sintomas para Desatenção e Hiperatividade/Impulsividade, sendo classificados como estando presentes ou ausentes seguindo quatro critérios de acordo com a versão brasileira da escala SNAPIV(MATTOS e colaboradores, 2006b) com atribuição de valores, conforme segue: nem um pouco (0), só um pouco (1), bastante (2), demais (3).

Para preencher os critérios diagnósticos para TDAH do tipo desatento foi necessário que se as respostas "bastante" e "demais" fossem apresentadas em pelo menos 6 dos 9 sintomas desatenção. Para o TDAH do tipo hiperativo, foram necessárias respostas "bastante" e "demais" para 6 dos 9 sintomas de hiperatividade. Para o tipo combiando foram necessárias 12 respostas do mesmo tipo sendo no mínimo 6 relativas à desatenção e 6 relativas à hiperatividade. A mínima pontuação possível foi então de 6 pontos para entrar em um dos grupos (desatento ou hiperativo/impulsivo) e 12 pontos como critério para compor o grupo do tipo combinado.

Procedeu-se uma entrevista com os pais ou um dos responsáveis à confirmação do diagnóstico, seguindo-se os critérios do DSM-IV, incluindo a referência dos sintomas em mais de um ambiente, bem como, a manutenção dos sintomas, em pelo menos seis meses e a presença de sintomas antes dos sete anos de idade, estratégia ratificada noutros procedimentos, em que a conclusão diagnóstica foi realizada com critérios baseados no DSM-IV (FOLEY NICPON e colaboradores, 2004; KERNS e PRICE, 2001).

\subsubsection{Grupo Controle}


A formação do grupo Controle, constando 43 participantes sem TDAH (31 meninas, 12 meninos), procedeu-se a seleção em duas escolas (Colégio Oficina e Colégio Portinari) de ensino privado, em Salvador (BA), procedendo-se em três fases, assim descriminadas:

a) solicitação aos coordenadores de alunos com 11 anos, 0 mês e 0 dia a 14 anos, 11 meses e 29 dias, que realizassem seleção a partir da observação da ausência de sintomas de desatenção ou hiperatividade/impulsividade, preenchendo a escala de TDAH para professores (BENZICK, 2000), que foi posteriormente corrigida e verificada a presença ou ausência de sintomas indicativos do TDAH;

b) encaminhamento aos pais de carta convite e um questionário similar ao do grupo TDAH, incluindo os mesmos itens coletados aos participantes com diagnóstico de TDAH, tendo em anexo o termo de consentimento livre e esclarecido. Cada criança, foi caracterizada por seus pais como saudável, sem o preenchimento de critérios para o transtorno, sem outro diagnóstico psiquiátrico ou uso de medicação psicotrópica;

c) os dados foram comparados para idade e escolaridade e os pais foram comunicados por telefone, para agendar as crianças à aplicação dos testes e procedimentos experimentais inerentes à pesquisa.

\subsection{Instrumentos e Procedimentos}

Para a aplicação de todos os instrumentos, tanto do grupo experimental quanto do grupo controle, foi selecionada uma sala isolada, no consultório e na escola, respectivamente, com o mínimo possível de interferência externa e durante todo o procedimento o participante esteve somente com o examinador na sala fechada.

\subsubsection{MEMO: Avaliação de Memória}

O instrumento principal utilizado para avaliação neuropsicológica dos pacientes foi o "Memo", desenvolvido por Mello e Abreu (2000). Para se tornar mais compatível com outras máquinas e facilitar o manejo, o instrumento foi adaptado, para que o 
procedimento experimental pudesse ser realizado com uso de um programa amigável, sendo selecionado o software Powerpoint do pacote Office 2003 da Microsoft.

Inicialmente, foram selecionados 20 estudantes de ambos os sexos ( 5 da $5^{\text {a }}$ série, 11 anos de idade; 5 da $6^{a}$ série, 12 anos de idade; 5 da $7^{\text {a }}$ série, 13 anos de idade 5 da $8^{a}$ série, 14 anos de idade), sem sinais clínicos de dificuldades comportamentais e cognitivas que formaram o grupo piloto. Quatro matrizes, com 16 figuras cada uma para identificação e nomeação foram apresentadas em uma única sessão. As figuras ficaram expostas por no máximo 5 minutos para nomeação. Todas as figuras foram reconhecidas pelos indivíduos e avaliadas como nomeáveis. As variações nos nomes das figuras (e.g. barco, navio) foram registradas para servirem como padrão para uso posterior na aplicação das matrizes nos grupos caso e controle (Apêndice $C$ ).

Iniciou-se o desenvolvimento experimental, sendo expostas numa tela de computador tipo notebook Acer, modelo Aspire 3623WXMi, com tela de 15", quatro apresentações em arquivo do software Powerpoint, sendo caracterizadas cada uma como condição experimental, pormenorizadas na seqüência:

\subsubsection{Categorial seriada}

16 (dezesseis) figuras nomeáveis, de quatro grupos diferentes: frutas, animais, meios de transporte e vestuário, foram apresentadas automaticamente, cada uma durante cinco segundos em três tentativas, sendo que em cada uma das tentativas, o participante evocou livremente os itens visualizados na apresentação (Figura 2). As evocações foram registradas na ordem emitida pelo indivíduo (Apêndice $D$ ), não sendo corrigidas nem oferecidas dicas sobre o desempenho do indivíduo. O número total de itens corretos serviu como variável dependente para cada uma das três tentativas. 


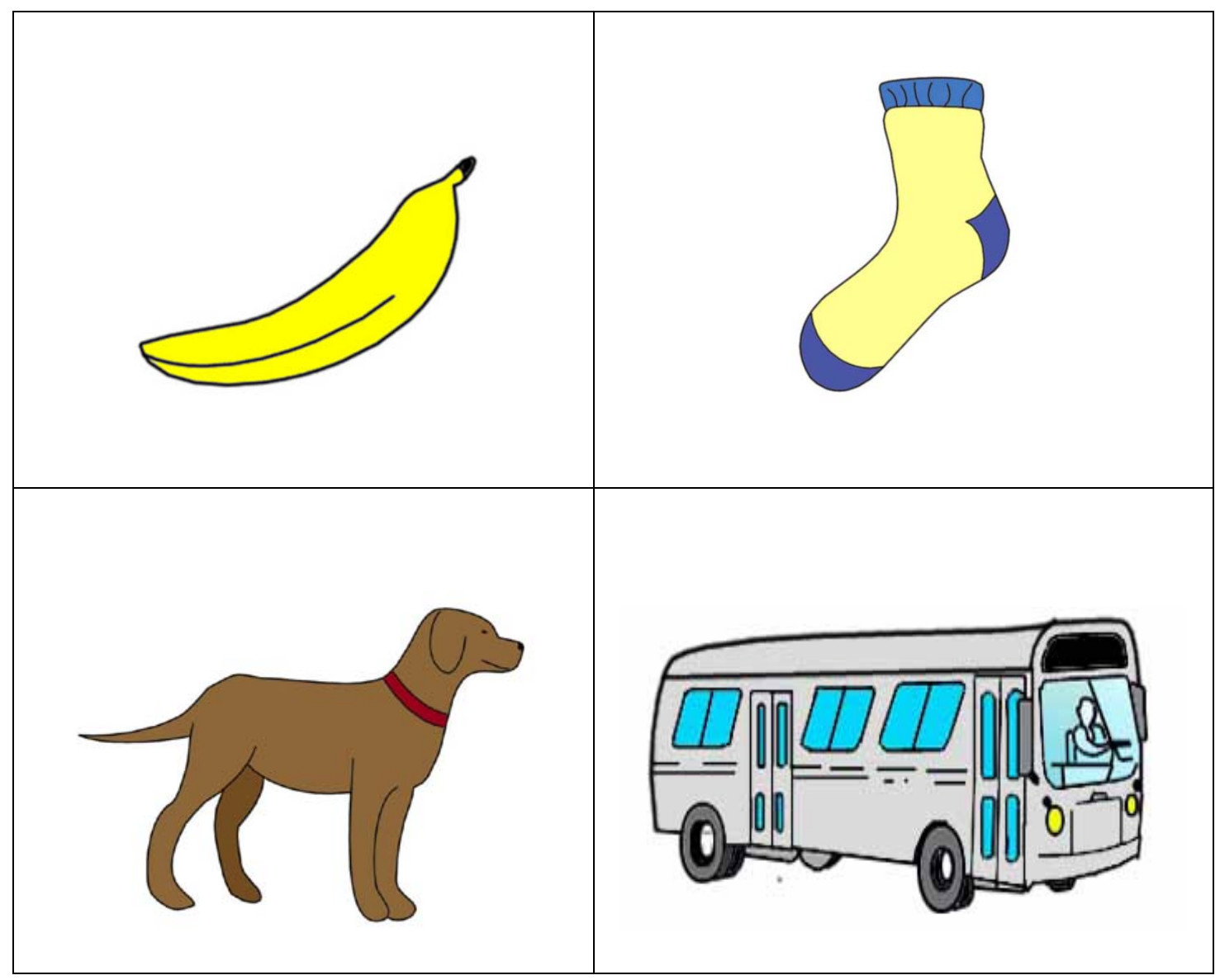

Figura 2 - Exemplos de figuras da apresentação categorial seriada.

. O número de itens por tentativa e o número total de itens evocados nas três tentativas constituíram escores de desempenho de aprendizagem para a condição categorial seriada. Após 20 minutos, solicitou-se ao participante, que evocaram livremente o máximo possível de nomes de figuras, sem que este fosse informado anteriormente sobre a necessidade de recordação posterior. O número total de itens evocados constituiu o escore de memória de longa duração para a condição um (1).

\subsubsection{Categorial agrupada}

16 (dezesseis) figuras nomeáveis, de quatro grupos diferentes: frutas, animais, meios de transporte e lanches (e.g. hambúrguer, batatas-fritas), foram apresentadas automaticamente, em uma única apresentação de 60 segundos de duração (Figura 3). Após a apresentação, o participante evocou livremente os itens visualizados. As 
evocações foram registradas na ordem emitida pelo indivíduo, não sendo corrigidas nem oferecidas dicas sobre o desempenho do indivíduo. O número total de itens corretos serviu como variável dependente do desempenho de memória imediata para a condição categorial a grupada. Após 20 minutos, foi solicitado ao participante que evocasse livremente o máximo possível de nomes de figuras, sem que este fosse informado anteriormente, sobre a necessidade de recordação posterior. O número total de itens evocados corretamente constituiu o escore de memória de longa duração para a condição dois (2).
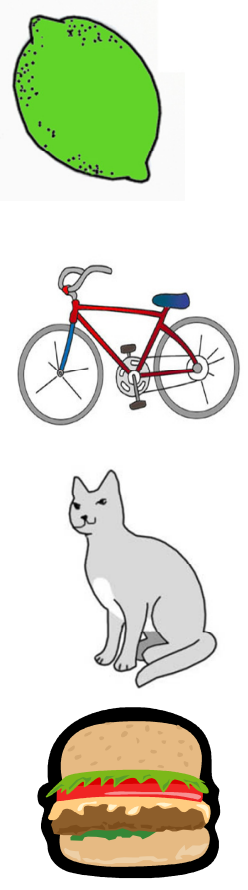
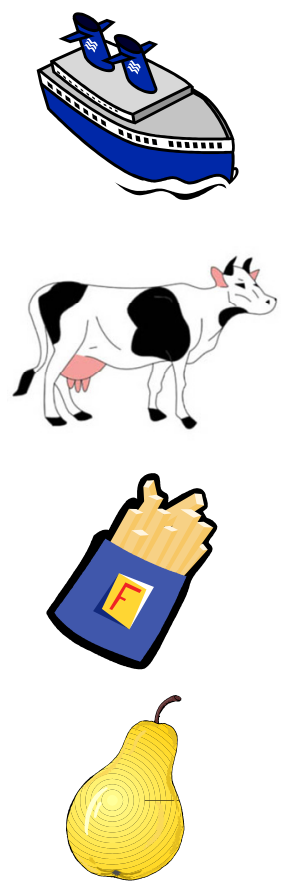
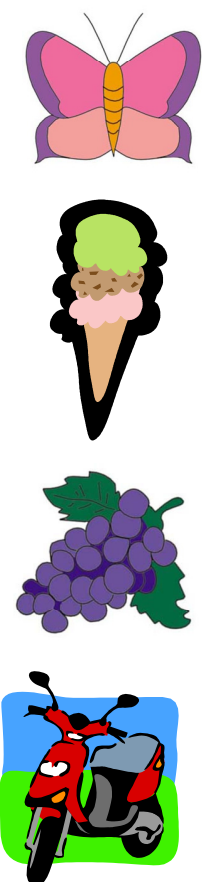
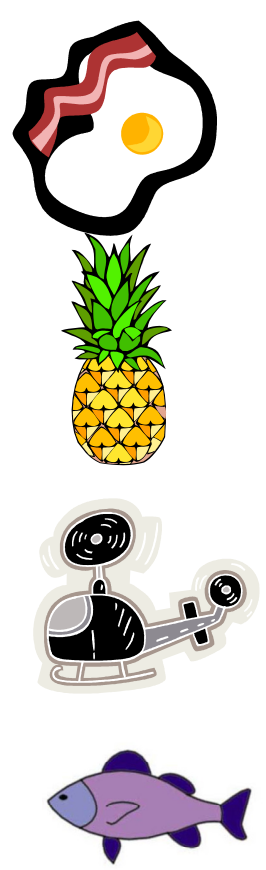

Figura 3 - Matriz da apresentação categorial agrupada.

\subsubsection{Não-categorial seriada}

16 (dezesseis) figuras nomeáveis, não semanticamente relacionadas (poltrona, pizza, placa de trânsito, apito, extintor de incêndio, bola, boca, dentre outras), foram apresentadas automaticamente a cada uma durante cinco segundos, em três tentativas (Figura 4). Em cada uma das tentativas, o participante evocou livremente os itens 
visualizados na apresentação. As evocações foram registradas na ordem emitida pelo indivíduo, não sendo corrigidas nem oferecidas dicas sobre o desempenho do indivíduo. O número total de itens corretos serviu como variável dependente para cada uma das três tentativas. O número de itens por tentativa e o numero total de itens evocados nas três tentativas constituíram escores de desempenho de aprendizagem para a condição não-categorial seriada. Após 20 minutos, foi solicitado ao participante que evocasse livremente o máximo possível de nomes de figuras, sem que este fosse informado anteriormente sobre a necessidade de recordação posterior. O número total de itens evocados constituiu o escore de memória de longa duração para a condição 3;

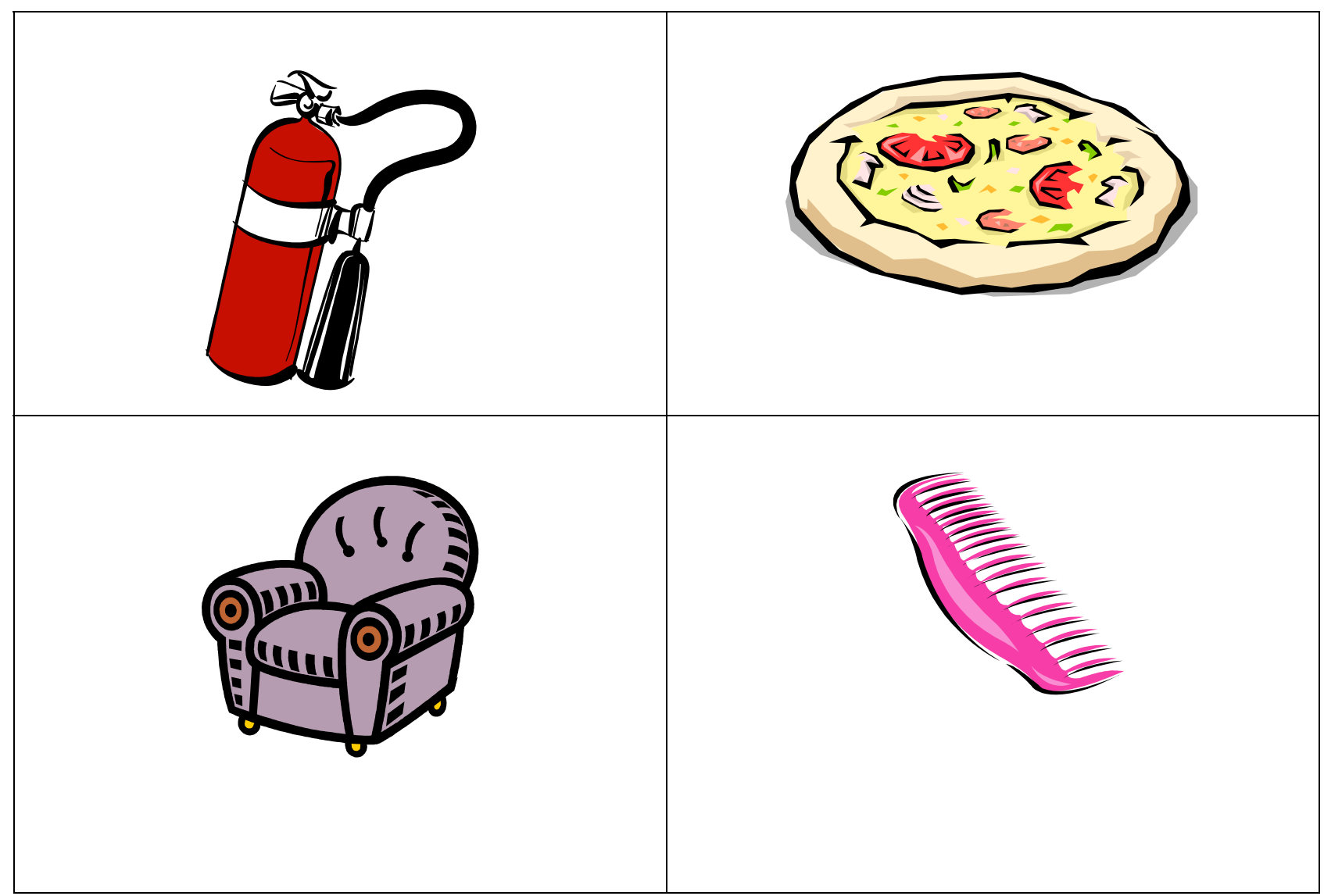

Figura 4 - Exemplos de figuras da apresentação não-categorial seriada.

\subsubsection{Não-categorial agrupada}

16 (dezesseis) figuras nomeáveis, não semântica relacionadas (relógio, martelo, violão, ônibus, pão, olho, chapéu, dentre outras), foram apresentadas automaticamente, em uma única apresentação de 60 segundos de duração (Figura 5). Após a apresentação, 
o participante evocou livremente os itens visualizados. As evocações foram registradas na ordem emitida pelo indivíduo, não sendo corrigidas nem oferecidas dicas sobre o desempenho do indivíduo. O número total de itens corretos serviu como variável dependente do desempenho de memória imediata para a condição não-categorial agrupada. Após 20 minutos, foi solicitado ao participante que evocasse livremente o máximo possível de nomes de figuras, sem que este fosse informado anteriormente sobre a necessidade de recordação posterior. O número total de itens, evocados corretamente, constituiu o escore de memória de longa duração para a condição 4.
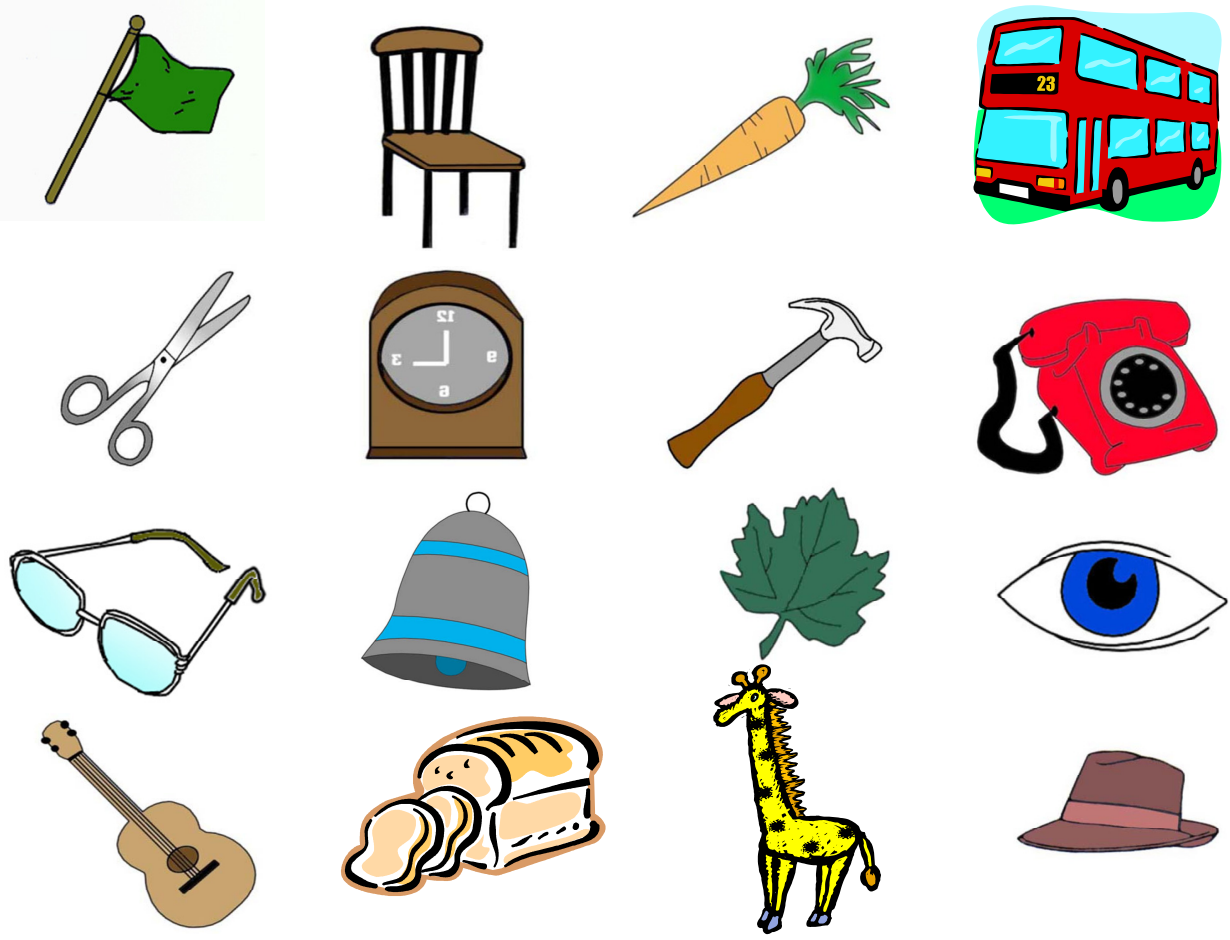

Figura 5 - Matriz da apresentação não-categorial agrupada.

As condições categorias e não categoriais foram apresentadas em dias diferentes, durante os dois encontros de avaliação realizados com os participantes. Os intervalos entre as apresentações dos estímulos nas condições seqüenciais, após a apresentação da terceira tentativa e nas condições agrupadas, após a apresentação do estímulo, foram preenchidos com testes de avaliação cognitiva e de atenção.

Para fins de padronização das aplicações todos os participantes, a não ser naqueles casos em que algum tipo de impedimento do participante interferisse, foram submetidos à aplicação dos testes, seguindo-se uma organização constante, conforme 
apresentadas na seqüência: apresentação (1) categorial seriada do "Memo"; provas 1,2 3 e 4 da bateria WISC III; evocação memória de longa duração da apresentação (1) e complementação WISC; apresentação (2) categorial agrupada do "Memo"; provas 5,6 7 e 8 da bateria WISC III; evocação memória de longa duração da apresentação (2) e complementação WISC; apresentação (3) não-categorial seriada do "Memo"; provas 9, 10, 11 e 12 da bateria WISC III; evocação memória de longa duração da apresentação (3) e complementação WISC; apresentação (4) não-categorial agrupada do "Memo"; provas 5,6 7 e 8 da bateria WISC III; evocação memória de longa duração da apresentação (2) e complementação WISC.

\subsubsection{WISC III: Avaliação de Inteligência}

Algumas pesquisas têm encontrado algumas diferenças, em funções executivas entre indivíduos com TDAH e indivíduos sem o transtorno, decorrentes das diferenças de QI, desaparecendo quando o QI torna-se uma co-variável (STEVENS e colaboradores, 2002). Apesar desta investigação não ser uma investigação básica de funções executivas, a associação do déficit com funções executivas é uma idéia bastante aceita (SEIDMAN e colaboradores, 2006). Para o isolamento tanto de fatores de retardo mental quanto do desempenho de funções especificas, como o índice de velocidade de processamento e o índice de resistência à distração, utilizou-se a bateria Wescheler Intelligence Scale for Children, terceira versão - WISC III (WESCHLER e FIGUEIREDO, 2002), um instrumento amplamente aceito, como escala de avaliação de inteligência. A bateria oferece ainda escalas em QI do desempenho global, verbal, executivo e índices de compreensão verbal e de organização perceptual, que também são utilizados na escala e são indicativos de prejuízos, em campos específicos experimentados por portadores do TDAH, tais como: memória operacional, solução de problemas, velocidade de processamento e organização (SEIDMAN e colaboradores, 2006; FUGGETA, 2006; DIAMOND, 2005, BARKLEY, 1997). A bateria foi aplicada ao longo de duas sessões, sendo os sub-testes realizados nos intervalos entre a evocação de curta duração das quatro condições da bateria MEMO e a evocação de longa 
duração, e entre os intervalos entre as condições-teste, conforme descrição na seção anterior.

\subsubsection{TAVIS 3: Avaliação de Atenção}

Para verificação do desempenho de funções atencionais utilizou-se o teste TAVIS - Versão 3 (DUSCHENE e MATTOS, 1997; COUTINHO e colaboradores, 2006), que consta de três subprovas desenhadas para a avaliação de três funções: atenção seletiva, alternância ou atenção dividida e atenção sustentada. A tarefa exigida é bastante simples para os participantes, principalmente na faixa etária da amostragem. Trata-se de apertar o botão de um joystick tipo manche, tarefa comum aos adolescentes, usados em jogos de videogames em computador. Os participantes foram submetidos às três provas da bateria no intervalo entre a evocação de memória imediata nos experimentos de memória e a evocação após o intervalo de 20 minutos. Nas três provas, descritas conforme segue, os participantes começaram com uma sessão de treino para adaptação à prova e aprendizagem do tipo de resposta.

\subsubsection{Atenção Seletiva}

$\mathrm{Na}$ primeira prova, estímulos coloridos (animais, para participantes até 11 anos de idade) e símbolos gráficos (para participantes de 12 a 14 anos) deveriam ser selecionados em meio a distratores de cor e forma apresentados sucessivamente. A resposta consistiu em apertar o botão com o dedo indicador da mão dominante, o mais rápido possível na apresentação do teste. O tempo entre a apresentação do estímulo e a reação do participante (apertar o botão do joystick) serviu como parâmetro para o critério tempo de reação (TR) da prova, uma clássica medida para avaliação de atenção (STERNBERG, 2002).

Além disso, dois outros fatores foram considerados: o número de erros de omissão (EO), quando o estímulo apareceu e o participante não respondeu apertando o joystick e o número de erros de ação (EA), quando o sujeito apertava antecipadamente o manche para um estímulo não apresentado ou confundido. Os escores do TR, EO e 
EA foram computados eletronicamente e os dados numéricos tabulados para análise estatística.

\subsubsection{Atenção Dividida}

$\mathrm{Na}$ segunda prova de atenção, denominada "atenção dividida", sendo duas condições apresentadas:

a. Para crianças até 11 anos, estas tinham que apertar o botão do joystick, todas as vezes que duas formas surgissem sob a seguinte condição, se estivesse escrito na tela a palavra igual, o participante deveria responder apertando o botão com o dedo indicador quando as duas formas fossem iguais se aparecesse a palavra "igual"; se escrita a palavra "diferente", quando as duas formas fossem diferentes. O tempo entre a apresentação do estímulo e apertar o botão foi considerado para registro do tempo de reação (TR) da prova. Além disso, dois outros fatores foram considerados: o número de erros de omissão, quando o estímulo apareceu e o participante não respondeu apertando o joystick e o número de erros de ação, quando o sujeito apertava antecipadamente o manche para um estímulo não apresentado ou confundido. Os escores do TR, EO e EA foram computados eletronicamente e os dados numéricos computados para análise estatística

b. para crianças entre 12 a 14 anos, foi recomendado apertar o botão sob a seguinte condição, se estivesse escrito na tela a palavra "forma", o participante deveria responder apertando o botão com o dedo indicador, quando as duas formas fossem; se escrita a palavra "cor", quando as duas cores das formas fossem iguais. O tempo entre a apresentação do estímulo e apertar o botão serviu como parâmetro para o critério tempo de reação (TR) da prova. Além disso, dois outros fatores foram considerados:

o número de erros de omissão, quando o estímulo apareceu e o 
participante não respondeu apertando o joystick e o número de erros de ação, quando o sujeito apertava antecipadamente o manche para um estímulo não apresentado ou confundido. Os escores do TR, EO e EA foram computados eletronicamente e os dados numéricos computados para análise estatística.

\subsubsection{Atenção Sustentada}

$\mathrm{Na}$ terceira prova, atenção sustentada, dois estímulos diferentes foram utilizados para a avaliação do desempenho dos participantes. Para os participantes de 11 anos, o desenho de um relógio de $2,0 \mathrm{~cm}$ foi apresentado em diferentes regiões da tela do computador com fundo escuro, com apresentação em intervalos aleatórios. Recomendou-se aos participantes que respondessem à apresentação do estímulo apertando o botão do joystick. Para os participantes de 12 a 14 anos o procedimento foi semelhante, com um estímulo diferente, um círculo $0,5 \mathrm{~cm}$ de diâmetro aparecia aleatoriamente na tela do computador, com intervalo aleatório e fundo escuro. O tempo de reação, número de erros de omissão e de erros de ação foram registrados segundo os critérios das primeira e segunda provas da bateria TAVIS-3.

\subsubsection{Visão de Cores}

Para verificar a presença de discromatopsia, devido a sua possível interferência na prova TAVIS-3, foi utilizada numa apresentação prévia à aplicação da bateria, uma versão abreviada informatizada do teste de Ishihara. O teste é constituído de vários círculos feitos de cores ligeiramente diferentes das cores daqueles situados nas proximidades. Seguindo o mesmo padrão, alguns círculos estão agrupados no meio do cartão de forma a exibir um número que somente será visível pelas pessoas que possuírem visão normal. Nenhum dos participantes apresentou erros na identificação dos estímulos. 


\subsection{Desenho Experimental e Análise Estatística}

O delineamento experimental foi planejado para possibilitar a comparação dentre os grupos de interesse (TDAH tipo desatento, hiperativo e combinado) e destes com o grupo controle. Para comparação das variáveis de características dos grupos foi utilizada uma Análise de Variância Unidirecionada (ANOVA) (idade, escolaridade, nível econômico, escolaridade materna, renda familiar, sexo, história escolar, transtornos associados e resultados na escala SNAP-IV).

Para análise das médias dos escores dos participantes nos testes "Memo", Testes de Atenção (Bateria TAVIS 3) e Bateria WISC III, utilizou-se uma Análise de Variância para Medidas Repetidas (ANOVA). Foram testados o efeito de grupo e o desempenho intragrupo.

Foi estabelecido o nível de significância estatística $p \leq 0,05$ para todas as análises realizadas. 


\subsection{Características Sócio-Demográficas e de Diagnóstico de acordo com os Grupos: TDAH de predomínio desatento $(n=17)$, TDAH de predomínio hiperativo $(n=11)$ e TDAH combinado $(n=16)$ e Controle $(n=43)$}

\subsubsection{Características Sócio-Demográficas}

Uma análise de variância unidirecionada (ANOVA) das características sócioeconômicas incluiu os seguintes fatores: idade, sexo (freqüência), escolaridade, renda familiar (RF) e escolaridade materna (EM). A ANOVA para fatores sócio-econômicos evidenciou ausência de diferenças significativas entre os grupos nos fatores idade, escolaridade e escolaridade materna. A Tabela 1 apresenta os dados sóciodemográficos para os grupos TDAH de predomínio desatento (TDAHD), TDAH de predomínio hiperativo (TDAHH) e TDAH combinado (TDAHC) e controle (Escola A + Escola $\mathrm{B}$ ), que responderam ao questionário sócio-demográfico. Os dados do grupo TDAH foram analisados para o fator grupo e a seguir realizadas comparações para específica entre os grupos.

Uma vez que o estudo foi desenhado para avaliar sujeitos com ajuste para idade e série, os resultados similares para idade e escolaridade entre os grupos não representam surpresa. Três fatores relevantes devem ser destacados. $O$ primeiro, o fator, a escolaridade materna (EM). Neste estudo, as mães dos sujeitos com TDAH e do grupo controle tiveram quase em sua totalidade ensino superior completo. De fato, neste estudo a renda familiar variou entre os grupos, caracterizando os indivíduos com TDAH provenientes da classe $B 1$ e do grupo controle na classe $A 2$ (ABEP, 2003). Houve um efeito de grupo marcado para o fator $\operatorname{RF}[F(3,83)=6,18 ; p<0,01]$. Entretanto, não houve diferenças entre os grupos TDAHD, TDAHH e TDAHC para o fator RF. 
Tabela 2. Características Sócio-Demográficas dos Pacientes com TDAHD, TDAHH, TDAHC e Controle

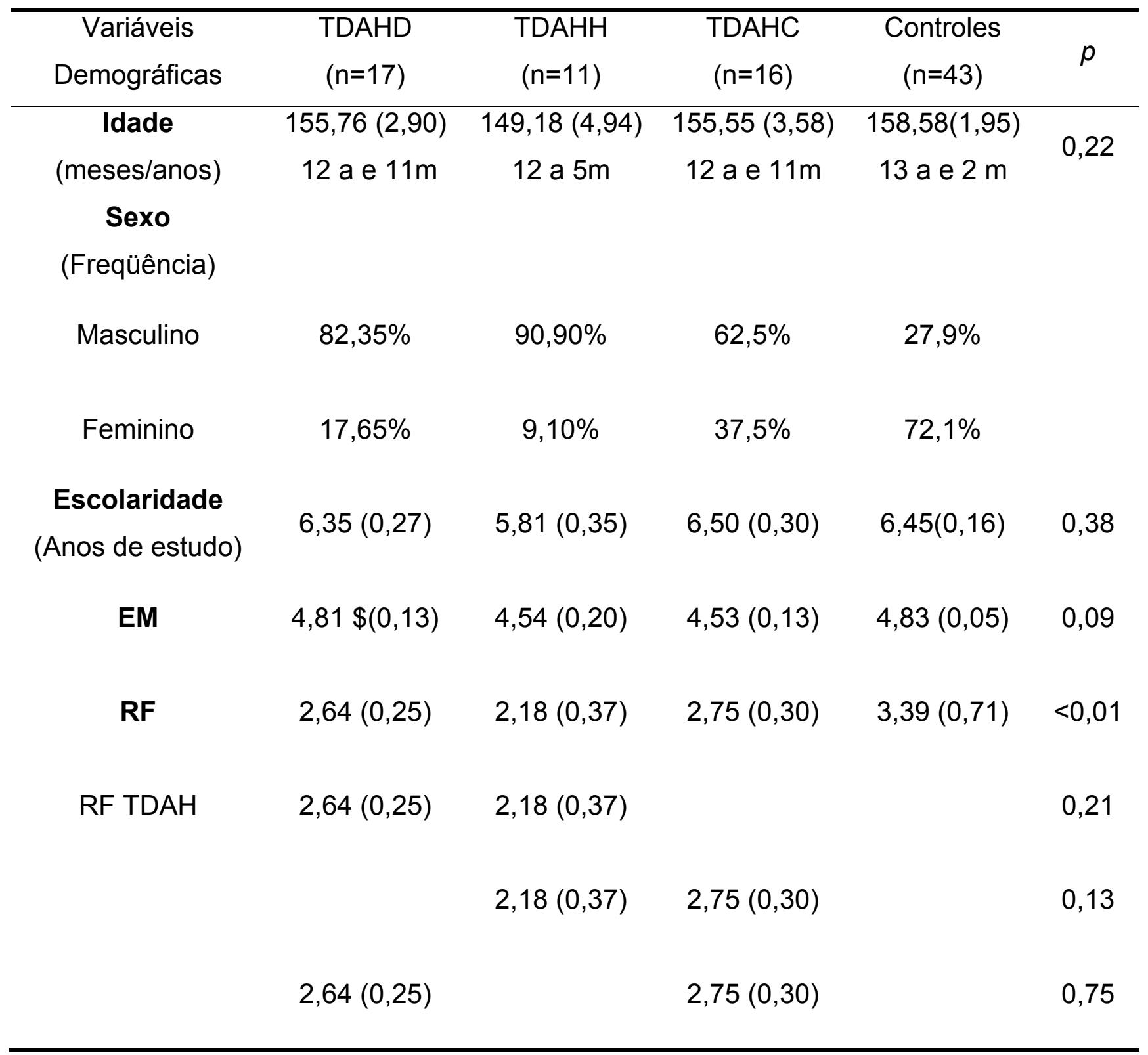

Médias (erro padrão), ANOVA; $p<0,05$;

TDAHD: Transtorno do Déficit de Atenção/Hiperatividade de predomínio desatento

TDAHH: Transtorno do Déficit de Atenção/Hiperatividade de predomínio hiperativo

TDAHC: Transtorno do Déficit de Atenção/Hiperatividade combinado

EM: Escolaridade Materna

RF: Renda Familiar (ABEP,2003)

RF TDAH: Renda familiar apenas para os casos TDAH

SNAP: Soma das respostas Bastante/Demais na Escala SNAP

EP: Escala de TDAH - Versão para Professores (Percentil) 


\subsubsection{Diagnóstico - Escala SNAP-IV}

A ANOVA para os critérios diagnósticos do TDAH (Tabela 3) através da escala SNAP-IV (SWANSON e colaboradores, 1994; Mattos e Colaboradores, 2006) revelou para a escala de desatenção (1) um efeito de grupo tanto para sintomas de desatenção [ $\left.\mathrm{F}_{3,83}=45,10 ; p<0,01\right]$; (2) ausência de diferenças significantes entre os grupos TDAHD e TDAHC [ $\left.F_{1,32}=0,0 p=1,0\right]$; (3) um efeito significante para 0 fator grupo quando comparados TDAHD e TDAHH $\left[\mathrm{F}_{1,27}=24,95 ; p<0,01\right]$ e (4) um efeito significante para o fator grupo quando comparados TDAHH e TDAHC [ $\left.\mathrm{F}_{1,26}=19,74 ; p<0,01\right]$.

Tabela 3. Características Diagnósticas dos Pacientes com TDAHD, TDAHH, TDAHC e Controle

\begin{tabular}{cccccc}
\hline Escalas para & TDAHD & TDAHH & TDAHC & Controles & $p$ \\
Diagnóstico & $(n=17)$ & $(n=11)$ & $(n=16)$ & $(n=43)$ & \\
\hline
\end{tabular}

SNAP

$\begin{array}{llllll}\text { Desatenção } & 6,15(0,61) & 3,00(0,72) & 6,06(0,52) & 0,25(0,13) & <0,01 \\ \text { Hiperatividade } & 2,35(0,41) & 6,90(0,93) & 6,18(0,95) & 0,16(0,12) & <0,01 \\ & & & & & \\ \text { Comportamento } & 2,35(0,53) & 3,54(0,69) & 3,69(0,65) & 0,16(0,05) & <0,01\end{array}$

EP

Desatenção $\quad 88,41(5,11) \quad 60,45(8,59) \quad 77,75(7,79) \quad 25,97(3,33) \quad<0,01$

Hiperatividade $\quad 68,76(6,06) \quad 88,45(3,38) \quad 76,81(7,23) \quad 29,72(3,61) \quad<0,01$ 
Tabela 3. Características Diagnósticas dos Pacientes com TDAHD, TDAHH, TDAHC e Controle Continuação

Problema de Aprendizagem $69,35(6,92)$ $56,36(8,42)$ $74,56(8,26)$ $13,41(2,45) \quad<0,01$ Comportamento $72,29(6,50)$ $71,91(6,95)$ $80,56(4,81)$ $46,04(3,86) \quad<0,01$

Médias (erro padrão), ANOVA; $p<0,05$;

TDAHD: Transtorno do Déficit de Atenção/Hiperatividade de predomínio desatento

TDAHH: Transtorno do Déficit de Atenção/Hiperatividade de predomínio hiperativo

TDAHC: Transtorno do Déficit de Atenção/Hiperatividade combinado

SNAP: Soma das respostas Bastante/Demais na Escala SNAP

EP: Escala de TDAH - Versão para Professores (em Percentis)

Os resultados obtidos na ANOVA para o fator grupo, relativos aos sintomas de hiperatividade na escala SNAP-IV revelaram que (1) houve efeito significante de grupo para sintomas de hiperatividade $\left[\mathrm{F}_{3,83}=82,65 ; p<0,01\right]$; (2) não houve diferenças entre os grupos TDAHH e TDAHC [ $\left.\mathrm{F}_{1,26}=1,26 p=0,26\right]$; (3) houve um efeito significante para o fator grupo quando comparados TDAHH e TDAHD [ $\left.F_{1,27}=51,58 ; p<0,01\right]$; (4) houve um efeito significante para $\mathrm{o}$ fator grupo quando comparados TDAHC e TDAHD [F $1,32=45,09 ; p<0,01]$

Em relação aos sintomas comportamentais da escala SNAP-IV, a análise estatística revelou que (1) houve diferenças para o fator grupo [ $\mathrm{F}_{3,83}=21,75 ; p<0,01$ ], evidenciando os sintomas comportamentais da escala nos três grupos com TDAH; (2) ausência de diferenças significativas entre as comparações dos grupos com TDAHH e TDAHC; e (3) uma diferença marginal entre o grupo com TDAHD e TDAHH [ $F_{1,27}=3,31$; $p<0,07]$.

\subsubsection{Diagnóstico - Escala de TDAH - Versão para Professores}

A análise dos percentis, que foram utilizados como os escores da Escala de TDAH para professores (BENZICK, 2000), revelou que houve diferenças para o fator grupo nas quatro escalas: desatenção $\left[F_{3,83}=34,90 ; p<0,01\right]$; hiperatividade $[F$ 
$3,83=29,39 ; \quad p<0,01] ; \quad$ dificuldades de aprendizagem $\left[\mathrm{F}_{3,83}=38,55 ; \quad p<0,01\right]$ e comportamento anti-social $\left[\mathrm{F}_{3,83}=21,75 ; p<0,01\right]$.

Em relação à observação dos professores mensurada na escala para desatenção a ANOVA revelou (1) diferenças entre os três grupos com TDAH e o grupo controle (Tabela 3); (2) diferenças significativas entre os grupos TDAHD e TDAHH [F $1,27=8,67 ; p<0,01]$; (3) ausência de diferenças entre os grupos TDAHD e TDAHC [F $1,32=1,56 ; p<0,21]$ e (4) uma diferença marginalmente significante entre os grupos TDAHH e TDAHC $\left[\mathrm{F}_{1,26}=3,24 ; p<0,07\right]$.

Os itens assinalados pelos professores na escala para hiperatividade revelaram na análise (1) diferenças entre os três grupos com TDAH e o grupo controle (Tabela 3); (2) diferenças significativas entre os grupos TDAHD e TDAHH [ $\left.F_{1,27}=4,53 ; p<0,03\right]$; (3) ausência de diferenças entre os grupos TDAHD e TDAHC [ $\left.F_{1,32}=0,93 ; p<0,33\right]$ e (4) ausência de diferenças entre os grupos TDAHH e TDAHC [ $\left.F_{1,26}=3,24 ; p<0,21\right]$.

Para a seção problemas de aprendizagem da escala para professores, a ANOVA revelou que (1) houve diferenças entre os três grupos com TDAH e o grupo controle (Tabela 3); (2) não houve diferenças significativas entre os grupos TDAHD e TDAHH [F $1,27=1,94 ; p<0,16]$; (3) não houve diferenças entre os grupos TDAHD e TDAHC [F $1,32=0,39 ; p<0,53$ ] e (4) que houve uma diferença marginalmente significativa entre os grupos TDAHH e TDAHC [ $\left.F_{1,26}=3,24 ; p<0,21\right]$, tendo o grupo com TDAHH obtido um escore menor na escala preenchida por professores.

Quanto à presença de sinais de comportamento anti-social, uma análise de variância das respostas dos professores à escala revelou que (1) houve diferenças entre os três grupos com TDAH e o grupo controle (Tabela 3); não foram observadas diferenças significativas entre os grupos: (2) TDAHD e TDAHH [F $\left.{ }_{1,27}=0,00 ; p<0,96\right]$; (3) TDAHD e TDAHC [ $\left.F_{1,32}=0,33 ; p<0,95\right]$ e (4) TDAHH e TDAHC $\left[F_{1,26}=0,84 ; p<0,36\right]$. 


\subsection{Avaliação de Memória}

Os resultados no experimento de avaliação de memória (MEMO) com as quatro apresentações (categorial seriada e agrupada; não-categorial seriada e agrupada) são apresentados a seguir para os subitens. Foram avaliados os escores separadamente por grupo em cada uma dos testes e comparações realizadas de acordo com o desenho experimental.

\subsubsection{Memória de Longa Duração Seriada (MLDS)}

A Figura 6 demonstra os resultados dos grupos na condição MLDS. Para estes resultados, uma ANOVA revelou (1) ausência de efeito significativo de grupo na memória de longa duração categorial com apresentação dos estímulos em série (MLDCS) [ $\left.\mathrm{F}_{3,85}=1,68 ; p=0.17\right] ;$; (2) efeito significativo de grupo na memória de longa duração não categorial com estímulos apresentados em série (MLDNCS) [ $F_{3,85}=3,23$; $p=0.02$ ]; (3) efeito significativo de grupo na comparação da média dos escores entre MLDCS e MLDNCS, fator MLDS , ou seja, a diferença do número de itens corretamente evocados pelos participantes dos três grupos com TDAH e grupo controle $F_{3,85}=3,26$; $p=0.02$ ]; (4) efeito do fator grupo no desempenho do grupo controle com o grupo TDAHH para a comparação MLDCS e MLDNCS [F $\left.{ }_{1,53}=6,99 ; p=0.17\right]$; ; (5) efeito do fator grupo no desempenho do grupo TDAHC com o grupo controle para a comparação MLDCS e MLDNCS [ $\left.F_{1,58}=4,94 ; p=0.02\right]$;.

\subsubsection{Memória de Longa Duração Agrupada (MLDA)}

Os resultados dos grupos na condição MLDA são apresentados na Figura 7. Uma ANOVA demonstrou (1) que houve efeito significativo para o fator grupo na memória de longa duração categorial com apresentação dos estímulos agrupados (MLDCA) $\left.\left[\mathrm{F}_{3,85}=8,25 ; p<0.001\right] ; 2\right)$ que houve efeito significativo de grupo na memória de longa duração não categorial com estímulos apresentados em matriz agrupada (MLDNCS) [ $\left.\mathrm{F}_{3,85}=8,32 ; p<0.001\right]$; (3) efeito significativo de grupo na comparação da 
média dos escores entre MLDCS e MLDNCS, fator MLDS, ou seja, a diferença do número de itens corretamente evocados pelos participantes dos três grupos com TDAH e grupo controle $\left[\mathrm{F}_{3,85}=12,22 ; p<0.001\right]$; (4) efeito do fator grupo no desempenho do

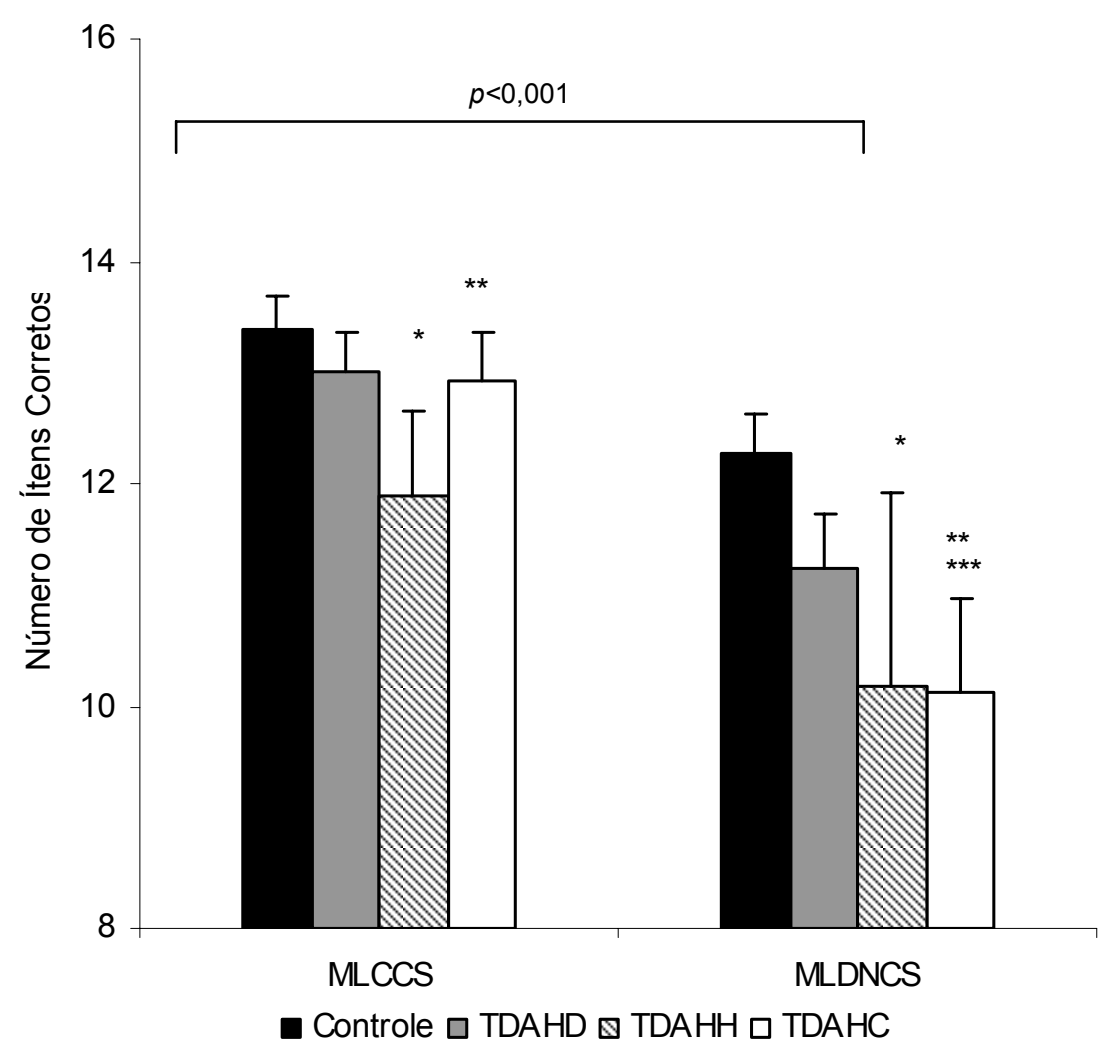

Figura 6. Comparação do Desempenho dos Grupos TDAHD, TDAHH e TDAHC e Controle na Memória de Longa Duração Seriada (MLDS). Média e erro padrão. * fator MLDS: Controle e TDAHH, $p=0,009$; ${ }^{* *}$ fator MLDS: Controle e TDAHH, $p=0,027 ;{ }^{* * *}$ fator MLDNCS: Controle e TDAHC.

grupo controle e dos grupos TDAHD [ $\left.\mathrm{F}_{1,59}=15,25 ; p=0,0002\right] ;$, TDAHH $\left[\mathrm{F}_{1,53}=22,46\right.$; $p<0.0001] ;$ e TDAHC $\left[F_{1,53}=16,73 ; p<0.0001\right]$ nas comparações das médias dos escores entre MLDCA e MLDNCA, ou seja, o fator MLDA. 


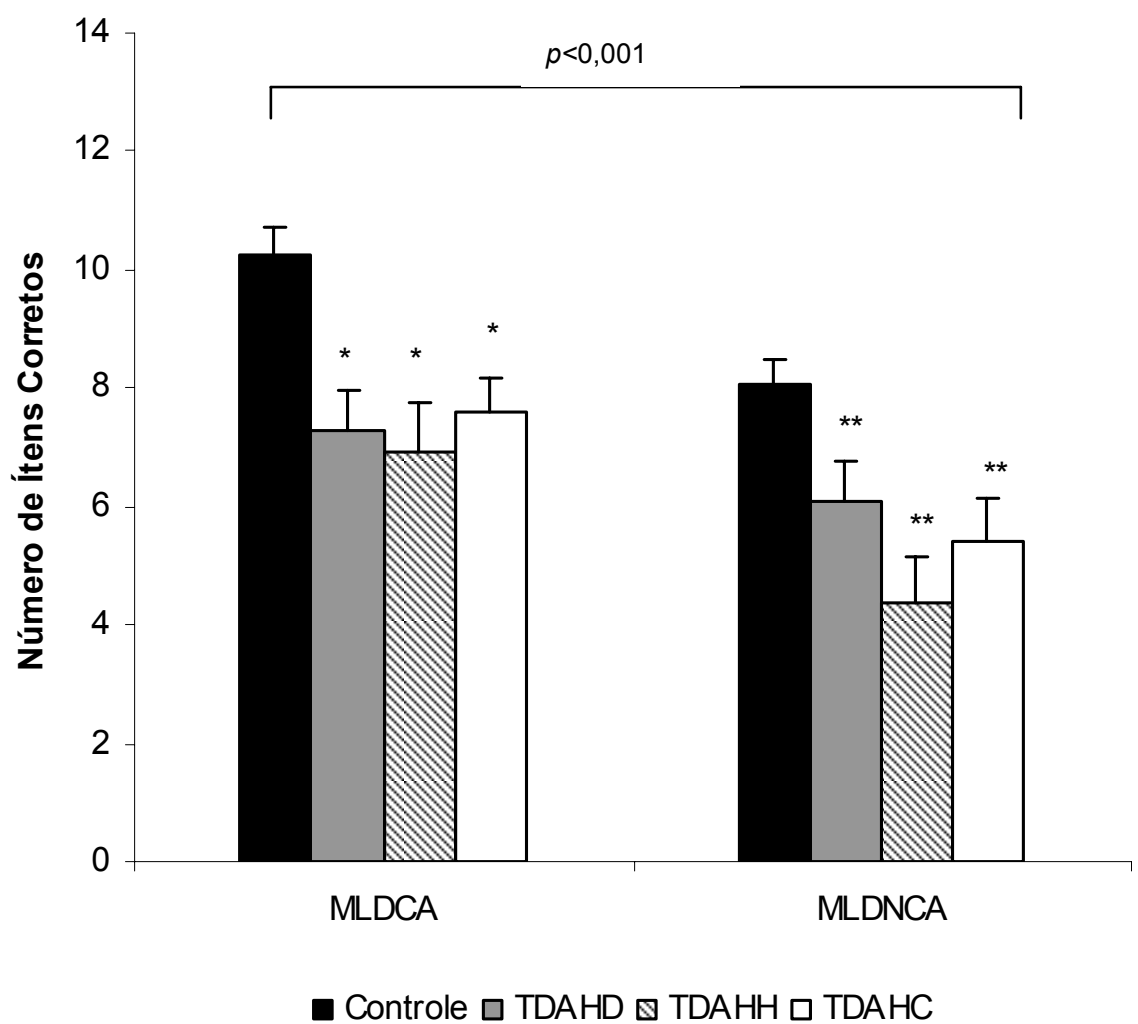

Figura 7. Comparação do Desempenho dos Grupos TDAHD, TDAHH e TDAHC e Controle na Memória de Longa Duração Agrupada (MLDA). Média e erro padrão. * fator MLDCA: Controle e TDAHD, TDAHH e TDAHC, $p<0,01$ ** fator MLDNCA: Controle e TDAHD, TDAHH e TDAHC $p<0,05$; fator MLDA, $p<0,001$.

4.2.3. Comparação das Médias dos Escores da Memória de Longa Duração Seriada (MLDS) e da $3^{a}$ Tentativa da Apresentação Seriada - Memória de Curta Duração Seriada (MCDS)

Um efeito do teste foi observado para um índice de perda entre a terceira tentativa de aprendizagem seriada categorial e não categorial, denominada de memória de curta duração seriada (MCDS) e a memória de longa duração seriada (MLDS) [F $1,83=13,61 ; p<0.001]$. Os resultados desta comparação, memória seriada (MS) estão apresentados na Figura 8. Os valores percentuais foram resultantes da aplicação de uma fórmula desenhada neste trabalho pelo autor para este índice que se denomina 
índice de desempenho. Percentuais em valores positivos indicam um incremento entre a MCD e a MLD no número total de itens corretamente evocados. Percentuais em valores negativos indicam um decremento no número total de itens evocados.

Índice de Desempenho $(\%)=($ MLDCS-MCDCS $) \times 100 / M C D C S$

Índice de Desempenho $(\%)=($ MLDNCS-MCDNCS)X100/MCDNCS

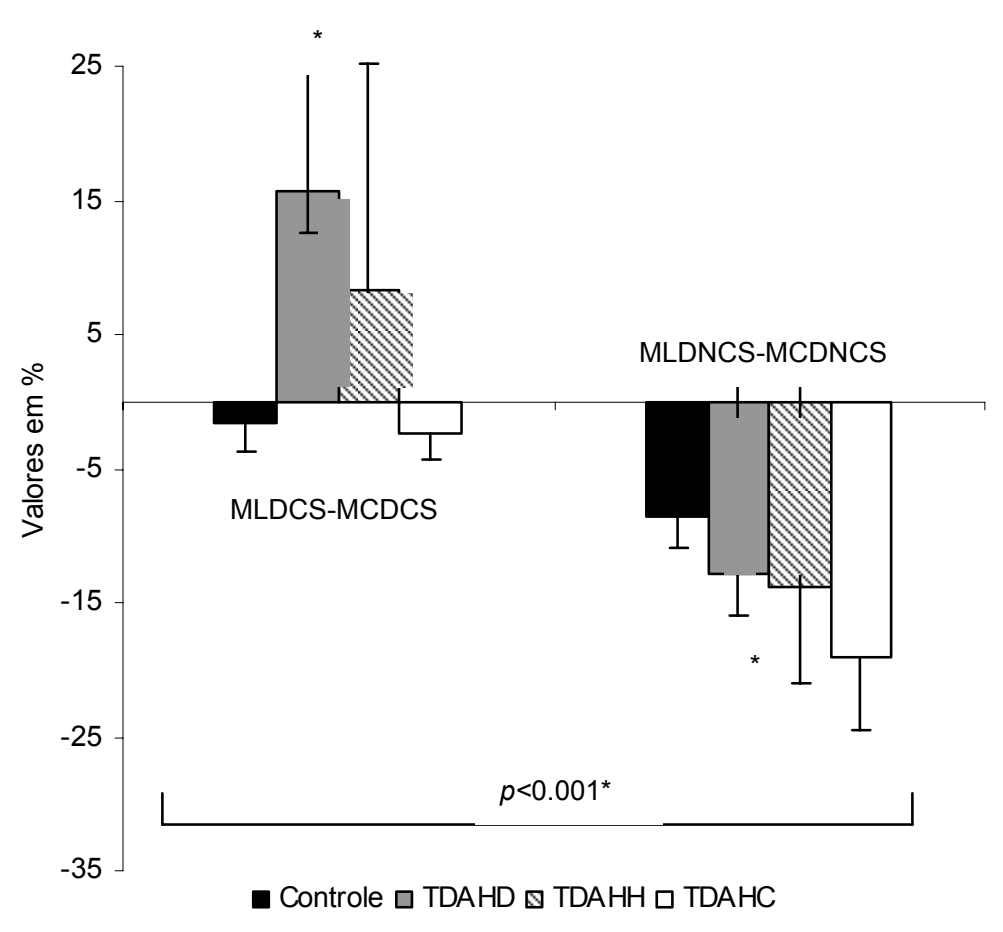

Figura 8. Índice de Desempenho para Comparação entre a Diferença dos Escores de Memória Seriada - MS. Média e erro padrão. * fator Categorial e Não Categorial: Controle e TDAHD, $p=0.07$.

Não houve diferenças entre os grupos TDAHD,TDAHH e TDAHC. Uma diferença marginal ocorreu quando foram comparados os índices de desempenho do grupo controle e TDAHD [F $\left.{ }_{1,59}=3,25 ; p=0,07\right]$. 
4.2.4. Comparação das Médias dos Escores da Memória Agrupada (MA) entre Memória de Longa Duração Agrupada (MLDA) e da Apresentação Agrupada - Memória de Curta Duração Agrupada (MCDA).

Um efeito de grupo foi observado para um índice de perda entre a apresentação agrupada categorial e não categorial, denominada de memória de curta duração agrupada (MCDA), e a memória de longa duração seriada (MLDS) $\left[\mathrm{F}_{1,83}=7,35\right.$; $p=0.0002]$. Os resultados desta comparação estão apresentados na Figura 9. Os valores percentuais foram resultantes da aplicação da fórmula índice de desempenho, aplicada aos escores de memória agrupada (MA). Percentuais em valores positivos indicam um incremento entre a MCD e a MLD no número total de itens corretamente evocados. Percentuais em valores negativos indicam um decremento no número total de itens evocados.

Índice de Desempenho $(\%)=($ MLDCA-MCDCA $) \times 100 / M C D C A$

Índice de Desempenho $(\%)=($ MLDNCA-MCDNCA)X100/MCDNCA

Em relação às comparações para $M A$, uma análise de variância para medidas repetidas revelou (1) ausência efeito do fator grupo no desempenho do grupo controle com o grupo TDAHD para a comparação MLDCA e MLDNCA (MA) [F ${ }_{1,59}=6,99$; $p=0.17$; ; (2) efeito do fator grupo no desempenho do grupo TDAHH [ $F_{1,53}=18,34$; $p<0.0001]$; (3) efeito do fator grupo no desempenho do grupo TDAHC e controle para a comparação MA [ $\left.\mathrm{F}_{1,58}=4,52 ; p=0.03\right]$.

$\mathrm{Na}$ comparação entre os grupos com TDAH a análise revelou ainda (4) efeito entre os grupos TDHAH e TDAHC [ $\left.F_{1,26}=4,43 ; p=0.03\right]$; e (5) efeito entre os grupos nas comparações categorial e não categorial para os grupos TDAHD e TDAHC $\left[\mathrm{F}_{1,32}=6,24\right.$; $p<0.014]$. 


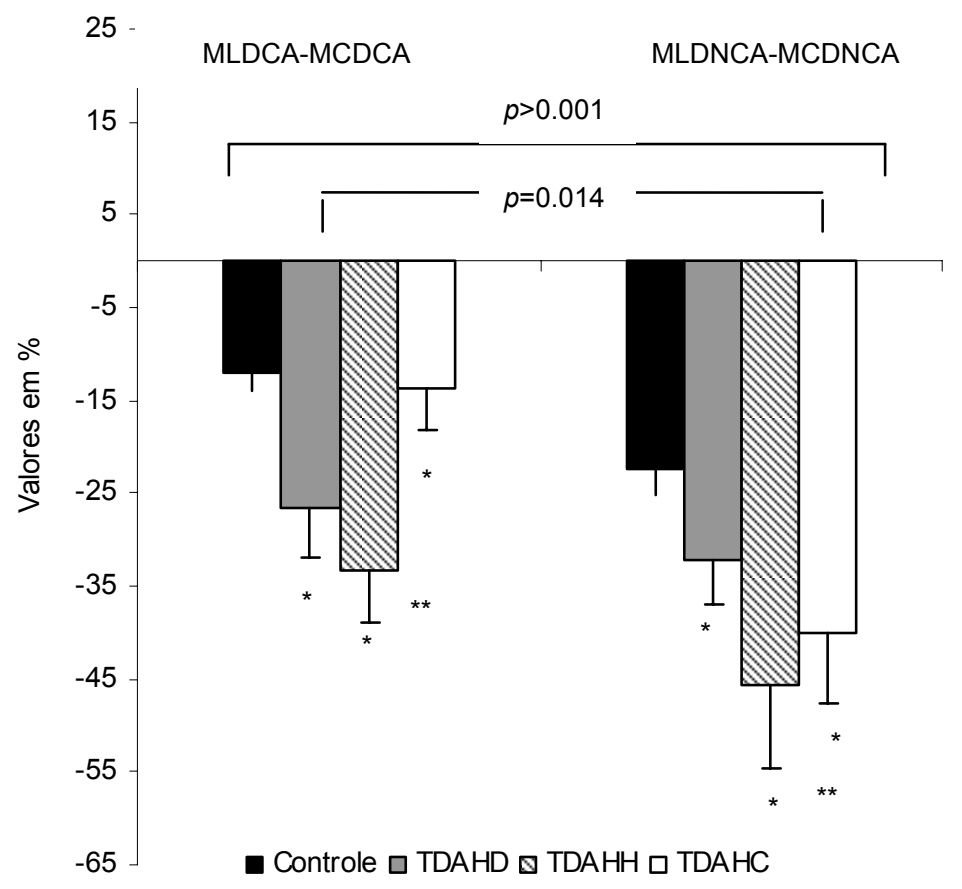

Figura 9. Índice de Desempenho para Comparação entre a Diferença dos Escores de Memória Agrupada - MA. Média e erro padrão. * fator Categorial e Não Categorial: Controle e TDAHD, $p=0.007$; Controle e TDAHH, $p<0.001$; Controle e TDAHC, $\mathrm{p}=0.003 .{ }^{* *}$ fator grupo TDAHH e TDAHC, $p=0.03$; fator apresentação categorial e não categorial TDAHD e TDAHC $(p=0,014)$.

4.2.5. Memória de Longa Duração Categorial Seriada (MLDCS) e Agrupada (MLDCA)

Os resultados para as diferenças entre os grupos no índice de desempenho MLDCS-MLDCA, revelaram através de uma análise de variância univariada (ANOVA) para a condição categorial (1) uma diferença significativa para os três grupos com TDAH quando comparados com o grupo controle, quais sejam: TDAHD $(p=0,001)$; TDAHH ( $p=0,006)$; e TDAHC ( $p=0,011)$; (2) ausência de diferenças significativas entre os grupos com TDAH (Figura 10, $p=0.574$ ). Para a condição não categorial a ANOVA revelou (3) um efeito marginalmente significativo de grupo para os escores percentuais obtidos a partir da fórmula para índice de desempenho $\left[F_{1,83}=3,66 ; p=0.52\right]$ e (4) ausência de diferenças significativas entre os grupos portadores do TDAH. Os escores 
foram obtidos e transformados em percentuais seguindo a fórmula descrita anteriormente adaptada para as variáveis dependentes analisadas:

Índice de Desempenho (\%)=(MLDCA-MCDCS)X100/MLDCS

Índice de Desempenho (\%)=(MLDNCA-MCDNCS)X100/MLDNCS

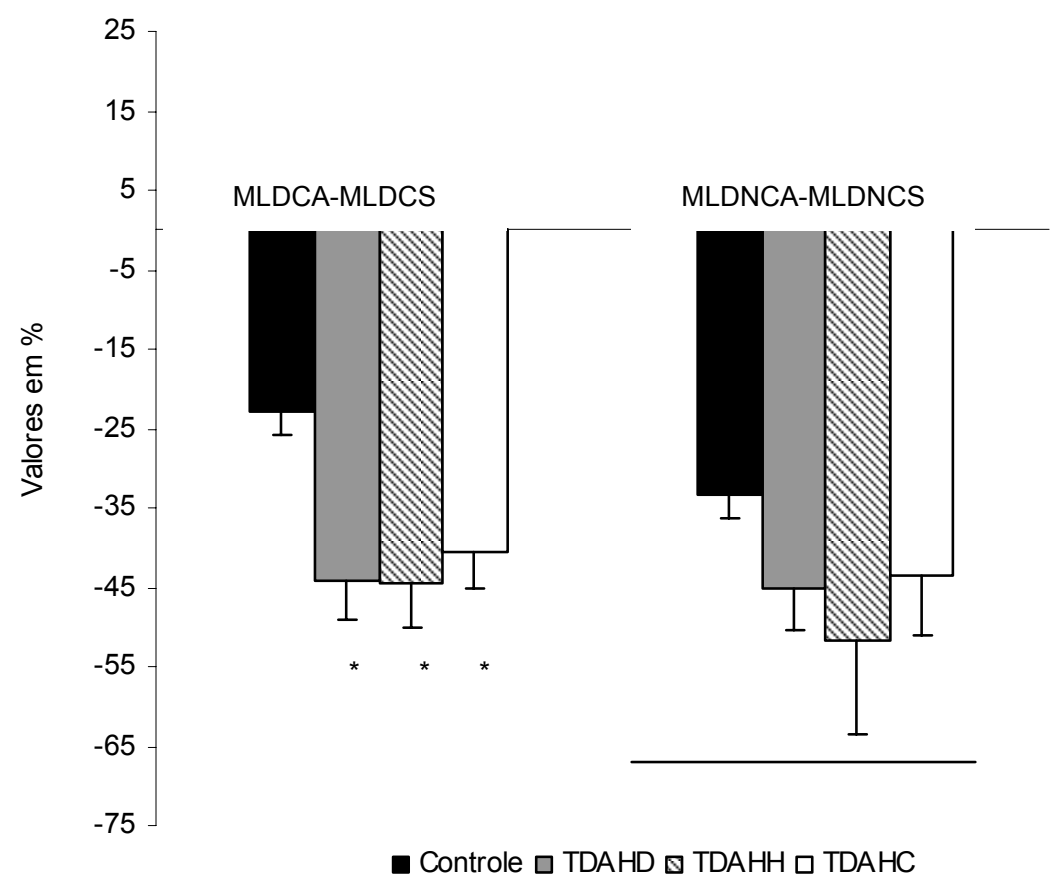

Figura 10. Índice de Desempenho para Comparação entre a Diferença dos Escores de Memória de Longa Duração Agrupada (MLDA) e Seriada (MLDS) Categorial (MLDCA/MCDCS) e Não Categorial (MLDCNCA/MLDNCS). Média e erro padrão. * Condição Categorial: diferença entre os grupos TDAHD, TDAHH e TDAHC $(p<0,05)$. Barra inferior indica um efeito de grupo marginalmente significativo $(p<0,052)$.

4.2.6. Aprendizagem Agrupada (APA) e Aprendizagem Seriada (APS-Tentativa 1)

A fim de analisar as diferenças no desempenho de aprendizagem imediata em diferentes condições categorial e não categorial de apresentação de estímulos para 
evocação, foi aplicado um índice de desempenho entre a APA e APS (tentativa 1). Os índices categorial e não categorial foram estabelecidos a partir das seguintes fórmulas.

Índice de Desempenho Categorial(\%)=(APCA-APCS)X100/APCS

Índice de Desempenho Não Categorial(\%)=(APNCA-APNCS)X100/APNCS

Não houve diferença para o fator grupo em nenhuma das condições do teste. Uma diferença foi observada, entretanto, quando comparados o desempenho do grupo controle e combinado (Figura 11) revelando um número menor de evocações na condição seriada $\left[\mathrm{F}_{1,58}=4,70 ; p=0.03\right]$.

\subsubsection{Aprendizagem Seriada (APS) Categorial e Não Categorial}

Aprendizagem seriada consistiu em apresentações das figuras para recordação por três tentativas para cada condição, categorial e não categorial. A comparação das duas condições de aprendizagem revelou através da ANOVA (1) uma forte tendência à diferença estatística entre os grupos $\left[F_{3,83}=2,60 ; p=0.052\right]$ na comparação entre as duas condições; (2) uma diferença entre os grupos controle e TDAHH F $_{1,53}=6,82$; $p=0.0107$ ] apenas na tentativa três não categorial; (3) uma diferença no fator condições categorial e não categorial $\left[\mathrm{F}_{3,83}=19,37 ; p<0.0001\right]$; (4) uma diferença no fator tentativa categorial e não categorial para todos os grupos [ $\left.F_{2,166}=196,27 ; p<0.0001\right]$; (5) uma diferença marginal para o fator tentativas 1,2 e 3 para as condições categorial e não categorial $\left[F_{2,166}=2,88 ; p<0.059\right]$; (6) uma diferença significativa para as condições categoriais e não categoriais, na média do número de itens (figuras) recordados entre as tentativas 1 e 3 [ $\left.F_{1,83}=4,60 ; p=0.035\right]$; As Figuras 12 e 13 apresentam os dados das tentativas das condições aprendizagem seriada categorial e não categorial para todos os grupos. 


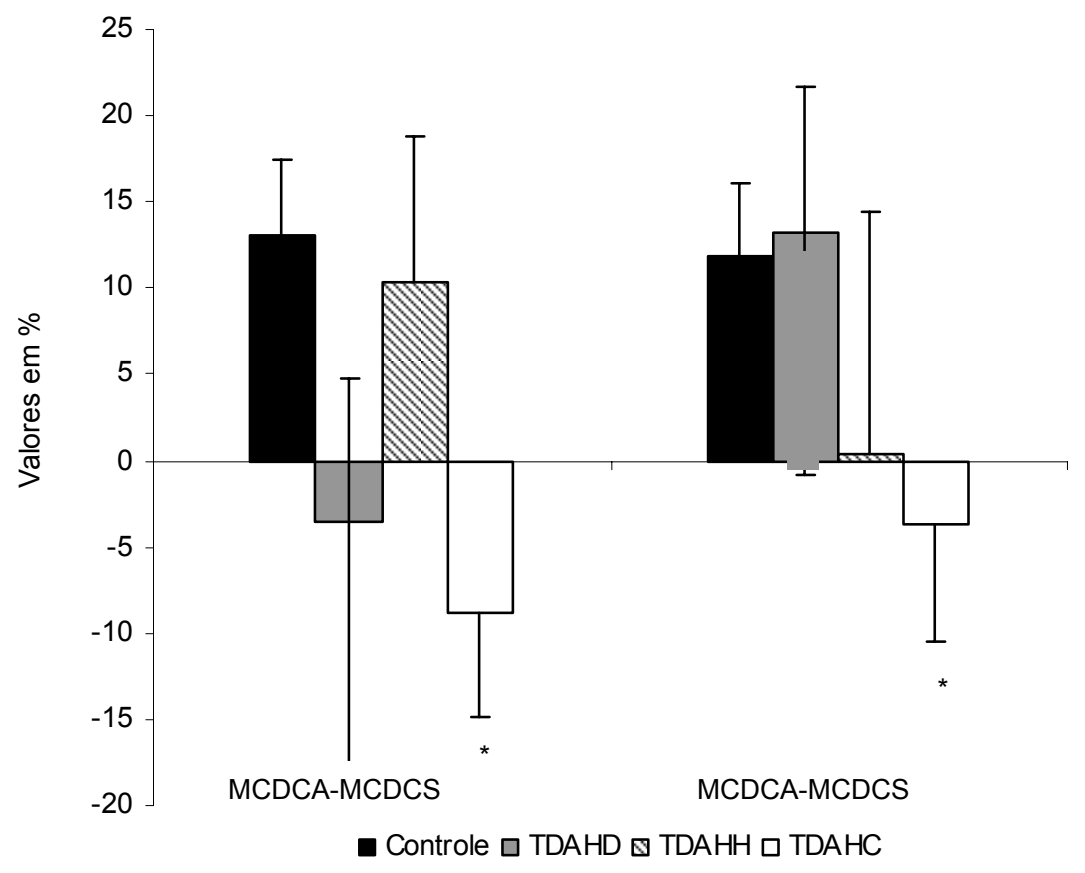

Figura 11. Índice de Desempenho para Comparação entre a Diferença dos Escores de Memória de Curta Duração Agrupada (MCDA) e Seriada (MCDS) Categorial (MCDCA/MCDCS) e Não Categorial (MCDNCA/MCDNCS). Média e erro padrão. * Condição Categorial e Não Categorial: diferença entre os grupos TDAHC e controle $(p<0,05)$. 


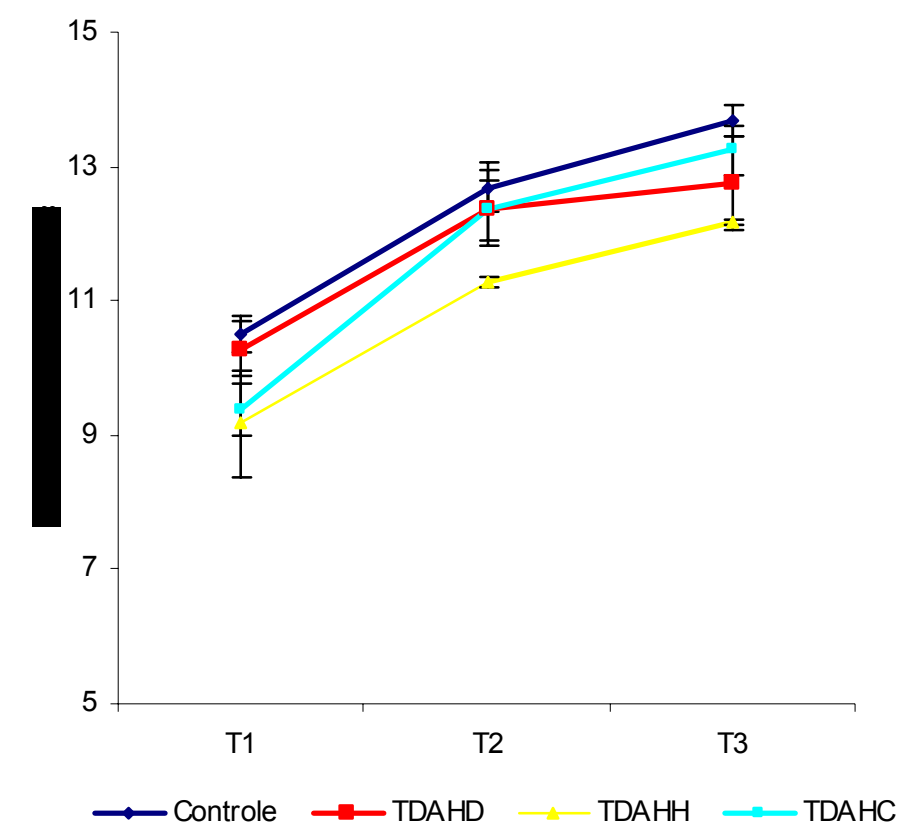

Figura 12. Aprendizagem Seriada Categorial. Média e erro padrão. T1, T2 e T3 são tentativas da aprendizagem seriada. Grupos TDAHD (predomínio desatento), TDAHH (predomínio hiperativo), TDAHC (combinado)

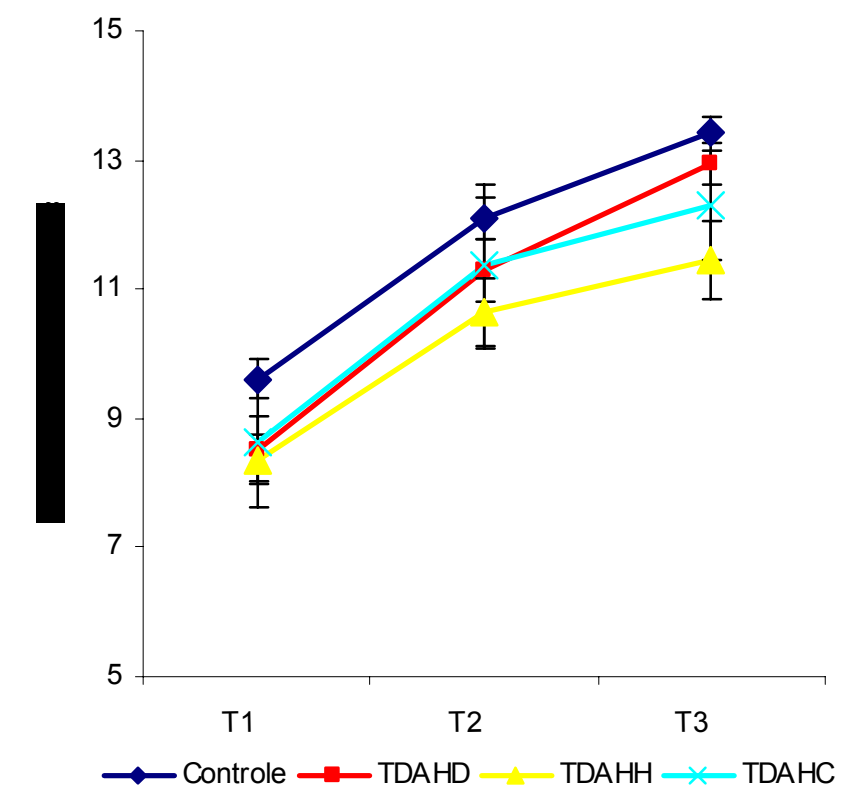

Figura 13. Aprendizagem Seriada Não Categorial. Média e erro padrão. T1, T2 e T3 são tentativas da aprendizagem seriada. Grupos TDAHD (predomínio desatento), TDAHH (predomínio hiperativo), TDAHC (combinado) 


\subsubsection{Aprendizagem Seriada (APS) e Aprendizagem Agrupada (APA)}

A Figura 14 apresenta os dados para aprendizagem agrupada e aprendizagem seriada categorial. A aprendizagem agrupada se caracterizou por uma única apresentação de uma matriz com 16 figuras por um minuto para recordação imediata e após um intervalo de 20 minutos (MLD). As comparações da APS e APA revelaram através de uma ANOVA (1) uma diferença significante entre os grupos para as condições de aprendizagem agrupada e aprendizagem seriada [ $\left.F_{3,83}=4,28 ; p<0.0074\right]$; (2) uma diferença marginalmente significante para os grupos controle e TDAHD [F 1,59=3,55; $p<0.07$ ]; (3) diferença significante entre os grupos Controle e TDAHH [F $1,53=9,81 ; p=0.002]$; e Controle e TDAHC [F $\left.{ }_{1,58}=4,94 ; p=0.02\right] ;$ (4) uma diferença significativa entre as condições categorial e não categorial [ $\left.F_{1,2}=28,94 ; p<0.0001\right]$.

Numa análise mais específica das variáveis separadamente a ANOVA revelou (5) uma diferença significante na média de escores para o grupo [ $F_{1,83}=28,94$ $p<0.0001$ ]; (6) uma diferença significante entre os escores do grupo controle e TDAHC para a comparação APS e APA para as tentativas 1,2 e 3 tendo o grupo combinado um pior desempenho[ $\left.\mathrm{F}_{1,53}=6,57 ; p=0.01\right]$; (7) diferenças marginalmente significantes para as tentativas 1,2 e 3 quando comparadas com a tentativa agrupada para os grupos TDAHD e TDAHH $(p<0,07)$.

\subsubsection{Aprendizagem Agrupada Categorial (APAC) e Não Categorial (APANC)}

Os resultados dos grupos nas comparações para aprendizagem agrupada (APA) são apresentados na Figura 15. Uma ANOVA para medidas repetidas evidenciou (1) um efeito de grupo significante [ $\left.\mathrm{F}_{3,83}=7,89 ; p=0.0001\right]$; (2) diferenças significantes para comparações do desempenho entre grupos controle e TDAHD [F $\left.{ }_{1,59}=7,85 ; p=0.006\right]$, Controle e TDAHH [F $\left.{ }_{1,53}=12,96 ; p=0.0005\right]$, e Controle e TDAHC [F ${ }_{1,58}=14,07$; $p=0.0003$; ; (3) um efeito significante para as condições agrupada categorial e não categorial $\left[F_{1,2}=10,40 ; p=0.0018\right]$; e (4) um efeito marginalmente significante para 0 fator grupo TDAHH e TDAHC $\left[\mathrm{F}_{1,2}=3,75 ; p<0,06\right]$. 


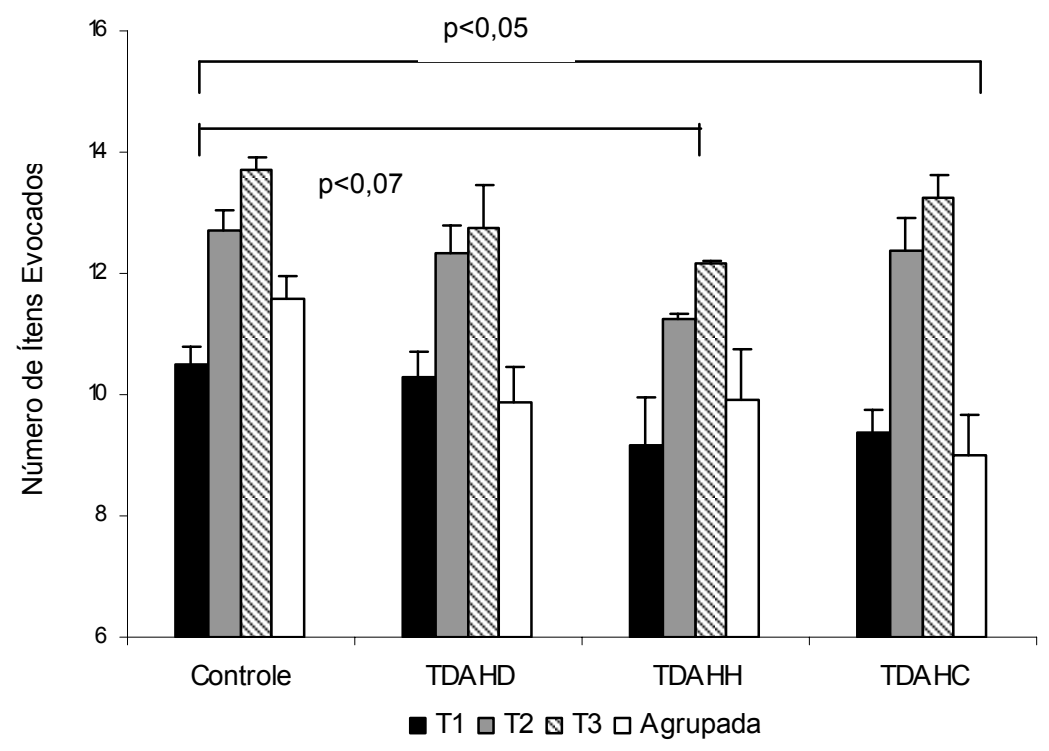

Figura 14. Aprendizagem Agrupada Categorial (APAC) e Aprendizagem Seriada Categorial (APSC). Média e erro padrão. * $p<0,05{ }^{* *} p<0,07$, para comparação T1 e Agrupada.

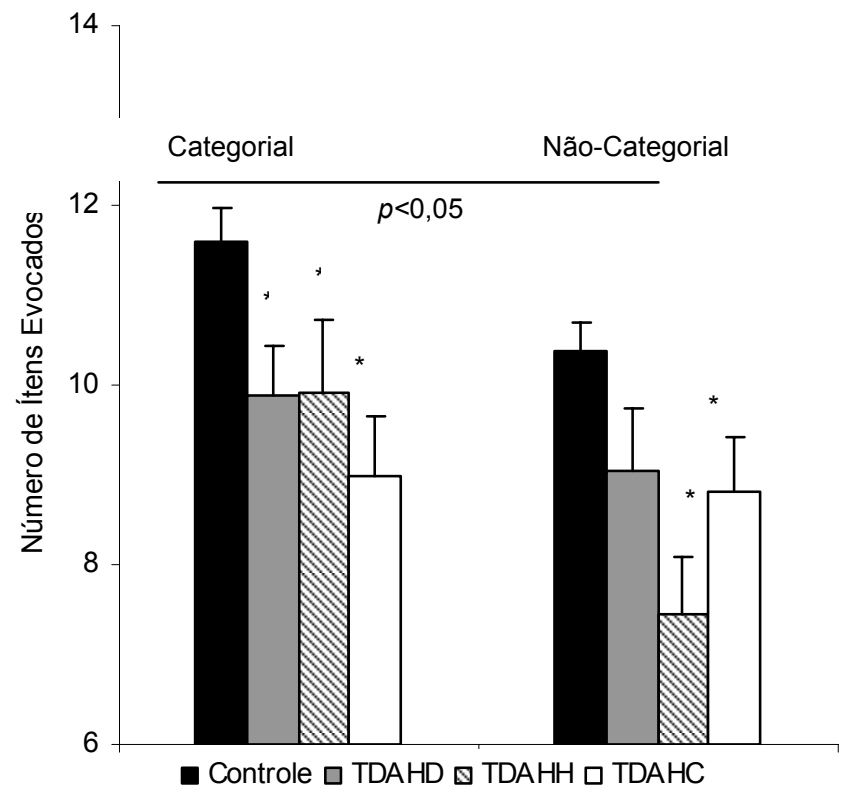

Figura 15. Aprendizagem Agrupada Categorial (APAC) e Aprendizagem Agrupada Não Categorial (APANC). Média e erro padrão. * $p<, 0,05$ para comparação TDAHD,TDAHH e TDAHC com o grupo controle. 


\subsubsection{0. Índice de Aprendizagem Categorial e Não Categorial}

Para análise de possíveis diferenças entre a aprendizagem com figuras categorizáveis não categorizáveis foi desenvolvido um índice de aprendizagem para esta investigação, resultante da soma dos valores absolutos das tentativas de aprendizagem seriada categorial (IAC)e não categorial (IANC) (Figura 16).

$$
\text { IAC: } \mathrm{T} 1+\mathrm{T} 2+\mathrm{T} 3
$$

IANC: $\mathrm{T} 1+\mathrm{T} 2+\mathrm{T} 3$

Uma ANOVA aplicada para estes índices revelou (1) um efeito de grupo marginalmente significante $\left[\mathrm{F}_{3,83}=2,60 ; p<0,06\right]$; (2) uma diferença significativa entre os grupos controle e TDAHH, que teve um desempenho inferior [ $\left.F_{1,53}=6,82 ; p=0.011\right]$; (3) um efeito para as condições categorial e não categorial $\left[F_{1,2}=19,37 ; p<0.0001\right]$.

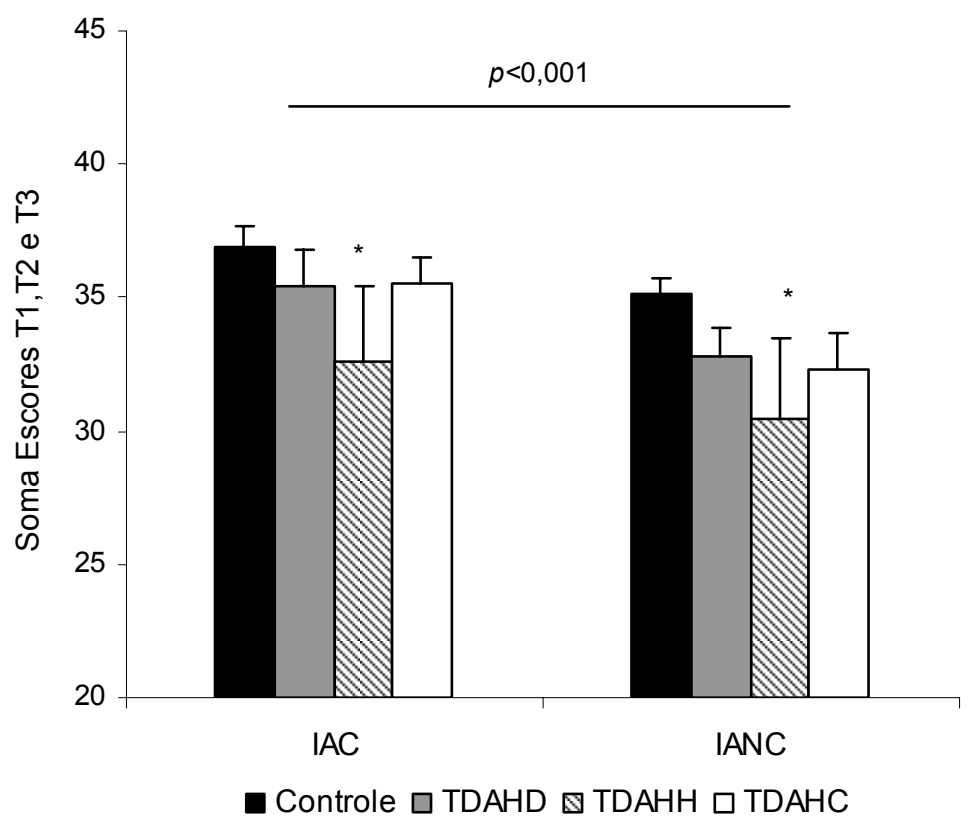

Figura 16. Índice de Aprendizagem Categorial (IAC) e Não Categorial (IANC). Média e erro padrão. * $p<0,05$. 


\subsection{Avaliação de Inteligência}

\subsubsection{Quoeficientes de Inteligência (QI)}

Os resultados na bateria de inteligência WISC III revelaram a partir de uma análise de variância (ANOVA): (1) um efeito de grupo para os fatores QI Verbal [F $3,83=28,13 ; p<0,001$ ]; QI Executivo [ $F_{3,83}=20,38 ; p<0,016$ ]; $\mathrm{Q}$ QI Total $\left[\mathrm{F}_{3,83}=20,38\right.$; $p<0,001]$. Uma análise post-hoc (Tukey HSD) revelou: (2) uma diferença significante para o QI Verbal entre o grupo controle e os grupos TDAHD ( $p<0,001)$, Controle e TDAHH ( $p=0.022)$, e Controle e TDAHC ( $p<0,001$ ]; (3) uma diferença significante para o QI Executivo somente entre o grupo controle e o grupo TDAHD $(p<0,005)$; e (4) uma diferença significante para 0 QI Total entre o grupo controle e os grupos TDAHD $(p<0,001)$, Controle e TDAHH $(p=0.016)$, e Controle e TDAHC $(p=0,001]$.

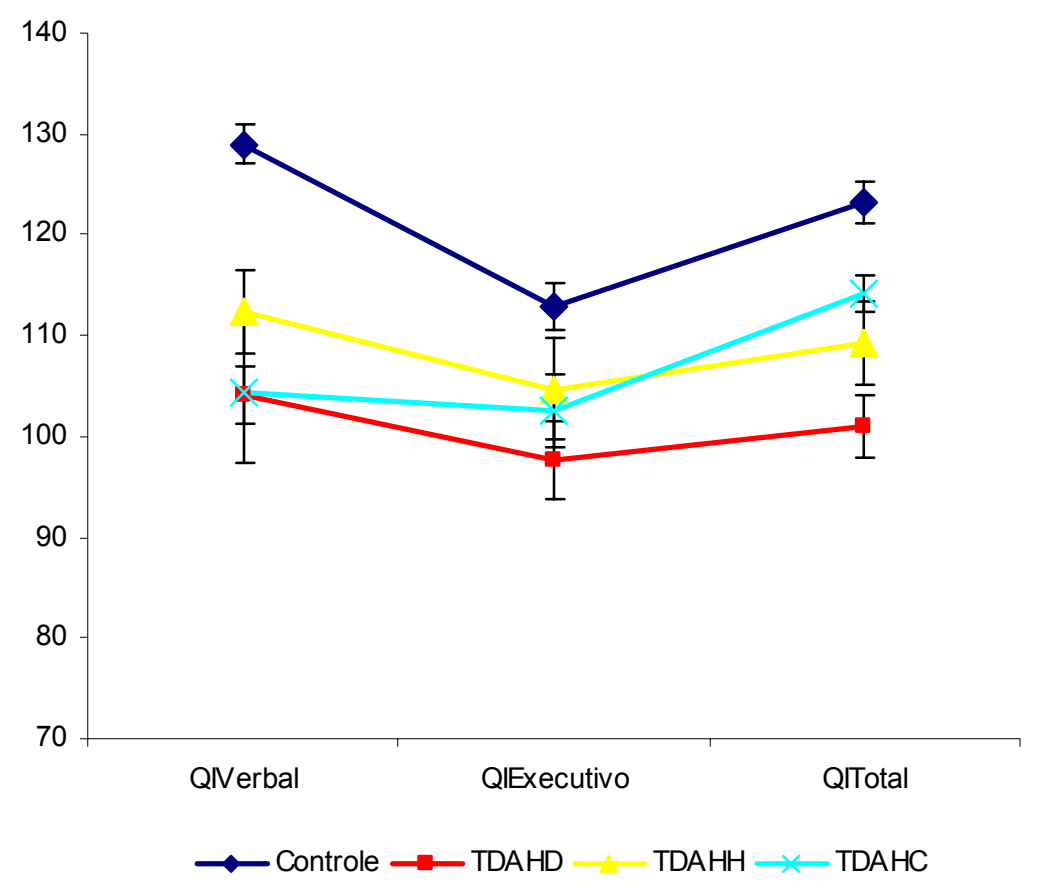

Figura 17. Quoeficientes de Inteligência Bateria WISC III. Médias dos QIs e erro padrão. 


\subsection{2. Índices Fatoriais}

Os 4 índices fatoriais da bateria WISC-III foram também analisados para os grupos. A ANOVA para os índices revelou (1) um efeito de grupo para o índice de compreensão verbal (ICV) $\left[F_{3,83}=13,39 ; p<0,001\right]$; (2) diferenças significantes entre o ICV do grupo controle e dos grupos TDAHD $(p<0,0001)$, TDAHH $(p=0,0003)$ e TDAHC $(p<0,0001)$; (3) que não houve diferenças entre os grupos portadores de TDAH. Para o índice de organização perceptual (IOP) (4) não houve diferenças entre os grupos [F $3,83=1,72 ; p<0,16]$.

Para o índice fatorial de resistência à distração (IRD), um índice bastante importante para avaliação de portadores do TDAH, a ANOVA revelou (5) um efeito de grupo significante $\left[\mathrm{F}_{3,83}=7,60 ; p=0,0002\right] ;(6)$ diferenças significantes entre $\circ$ IRD do grupo controle e dos grupos TDAHD $(p<0,0001)$, TDAHH $(p=0,0124)$ e TDAHC $(p<0,0020)$; $(7)$ ausência de diferenças entre os grupos portadores de TDAH. Para o índice de velocidade de processamento a análise revelou (8) um efeito de grupo significante [ $\left.\mathrm{F}_{3,83}=7,20 ; p=0,0002\right]$; (6) diferenças significantes entre $\circ$ IVP do grupo controle e dos grupos TDAHD ( $p<0,0001)$, TDAHH $(p=0,0065)$ e TDAHC $(p<0,0121)$; $(7)$ ausência de diferenças entre os grupos portadores de TDAH. 


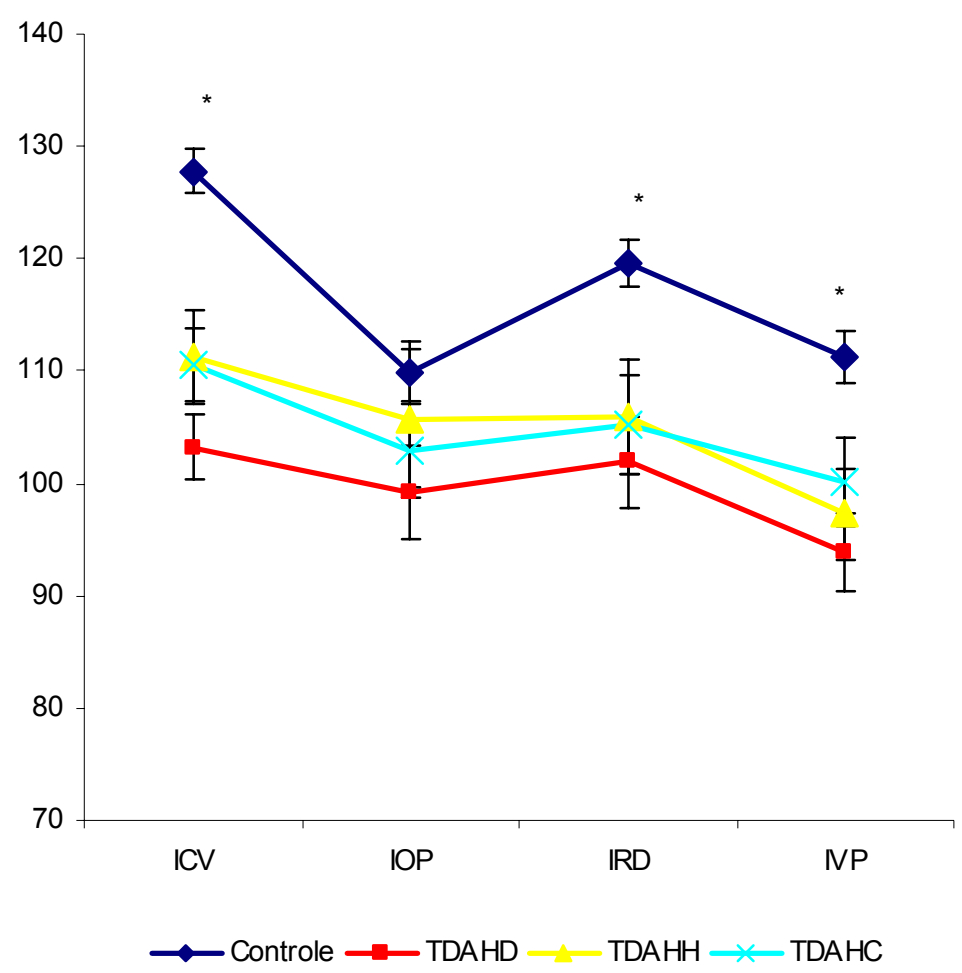

Figura 18. Índices Fatoriais da Bateria WISC III. Média dos índices e erro padrão. ICV: índice de compreensão verbal. IOP: índice de organização perceptual. IRD: índice de resistência à distração. IVP: índice de velocidade de processamento. ${ }^{*} p<0,05$.

\subsection{Avaliação de Atenção}

\subsubsection{Tempo de Reação}

Os escores dos participantes nos testes de atenção foram comparados também com uma ANOVA para analisar possíveis diferenças de desempenho. A análise estatística revelou em relação aos resultados na bateria TAVIS-3 (1) um efeito significante de grupo para a medida tempo de reação [ $\mathrm{F}_{3,77}=3,50 ; p=0,0193$; (2) uma diferença significativa no tempo de reação quando comparados os grupos controle e combinado ( $p=0,0018)$; (3) ausência de diferenças entre os grupos com TDAH para a medida tempo de reação quando as tarefas foram analisadas juntamente. 
Quando as tarefas foram analisadas uma a uma para o tempo de reação a ANOVA revelou (4) um efeito de grupo no tempo de reação na tarefa 1 (atenção seletiva) ( $p=0.0064)$; (5) diferenças no desempenho entre o grupo controle e TDAHC $(p<0.0001)$; (6) diferenças no desempenho dos grupos com TDAH, especificamente TDAHD e TDAHC $(p=0,012)$ TDAHH e TDAHC $(p=0,0201)$.

$\mathrm{Na}$ tarefa 2, de atenção dividida a ANOVA mostrou diferenças entre as médias [F $1,77=143,08 ; p<0,001]$, mas não houve diferenças entre os grupos participantes.

$\mathrm{Na}$ tarefa 3, de atenção sustentada, o tempo de reação registrado foi analisado para os grupos e a ANOVA revelou (7) um efeito significante de grupo $\left[\mathrm{F}_{3,77}=3,80\right.$; $p=0,0134]$, e (8) diferenças no desempenho do grupo com TDAHC com o grupo controle $(p=0,014)$, TDAHC e TDAHD $(p=0,033)$ e TDAHC e TDAHH $(p=0,021)$.

De fato, o desempenho no tempo de reação para o grupo TDAHC foi inferior, ou seja, os participantes do grupo reagiram aos estímulos-alvo em um tempo maior que os dos outros grupos (Figura 19)

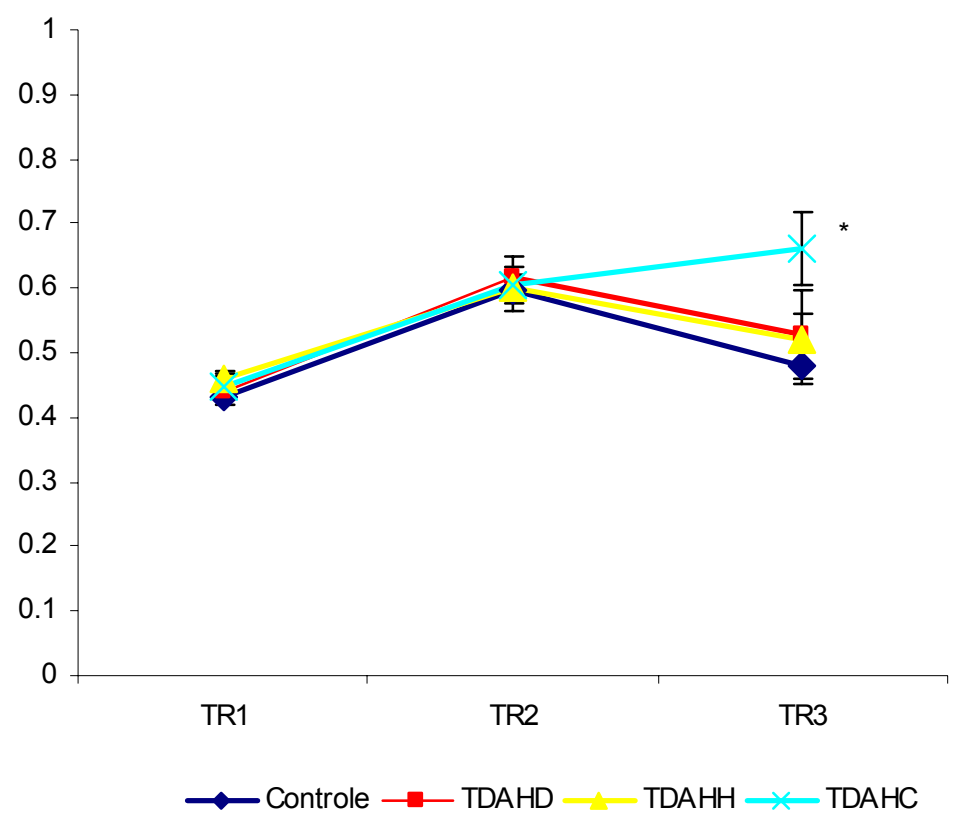

Figura 19. Tempo de Reação (TR) nas provas da Bateria TAVIS-3. Média e erro padrão. TR1: atenção seletiva; TR2: alternância; TR3: atenção sustentada. Eixo $Y$ em décimos de segundo. * $p<0,05$ 


\subsubsection{Erros por Omissão (EO)}

Os erros por omissão (desatenção) foram registrados para as tarefas em um arquivo eletrônico da Bateria TAVIS-3, e posteriormente os dados computados para análise estatística. Os escores estão apresentados na Figura 20. A ANOVA para EO revelou (1) um efeito significante de grupo $\left[\mathrm{F}_{3,77}=2,51 ; p=0,045\right]$; (2) uma diferença para o desempenho em EO para o fator tarefa $(p<0,0001)$. Este efeito é específico na tarefa 1 (3) com diferença significante para grupos controle e TDAHH ( $p=0,0031)$ e com (4) uma diferença marginal para os grupos controle e TDAHD $(p=0,007)$. Os escores de EO na tarefa 2 revelaram (5) uma diferença nas médias dos grupos $\left[F_{3,77}=12,93\right.$; $p=0,0006$; (6) uma diferença significante para os grupos controle e TDAHD $(p<0,05)$ e (7) uma diferença significante para os grupos controle e TDAHH $(p<0,05)$. Na tarefa 3 , de atenção sustentada, os erros por omissão foram presentes apenas para a comparação (8) entre os grupos controle e hiperativo (TDAHH) $(p=0,093)$.

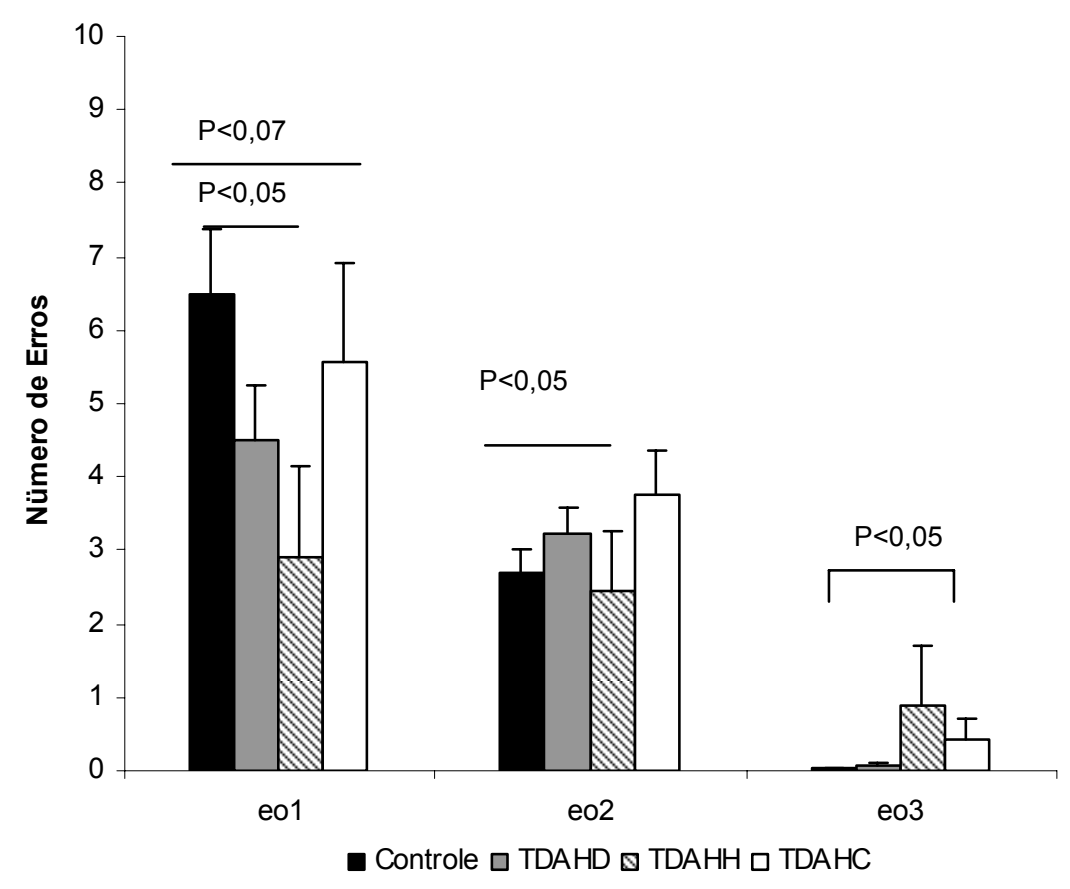

Figura 20. Erros por Omissão. Média e erro padrão. eo1: tarefa de atenção seletiva; eo2: tarefa de alternância; eo3: tarefa de atenção sustentada. 


\subsubsection{Erros por ação (EA)}

Os erros por ação (EA) foram registrados para as tarefas (Figura 21) em um arquivo eletrônico da Bateria TAVIS-3, e posteriormente os dados computados para análise estatística. A ANOVA para EA revelou (1) um efeito significante de grupo na tarefa 1 [ $\left.\mathrm{F}_{3,77}=77,11 ; p<0,0001\right]$; (2) uma diferença significante para a comparação dos erros por ação na tarefa 1 entre o grupo controle e o TDAHH, este com menor número de erros ( $p=0,0293)$; (3) uma diferença de média na tarefa $2(p<0,0001)$ para os grupos mas sem diferença significante entre os mesmos;(4) uma diferença de média na tarefa 3 ( $p<0,0001)$; (5) uma diferença marginalmente significante para o número de erros de ação dos grupos $(p<0,06)$ na tarefa $3 ;(6)$ uma diferença significante para a comparação do número de erros por ação na tarefa 3 para os grupos controle e TDAHH $(p=0,014)$ e $(7)$ uma diferença marginalmente significante para a comparação dos EA na tarefa 3 para os grupo controle e TDAHC $(p<0,06)$.

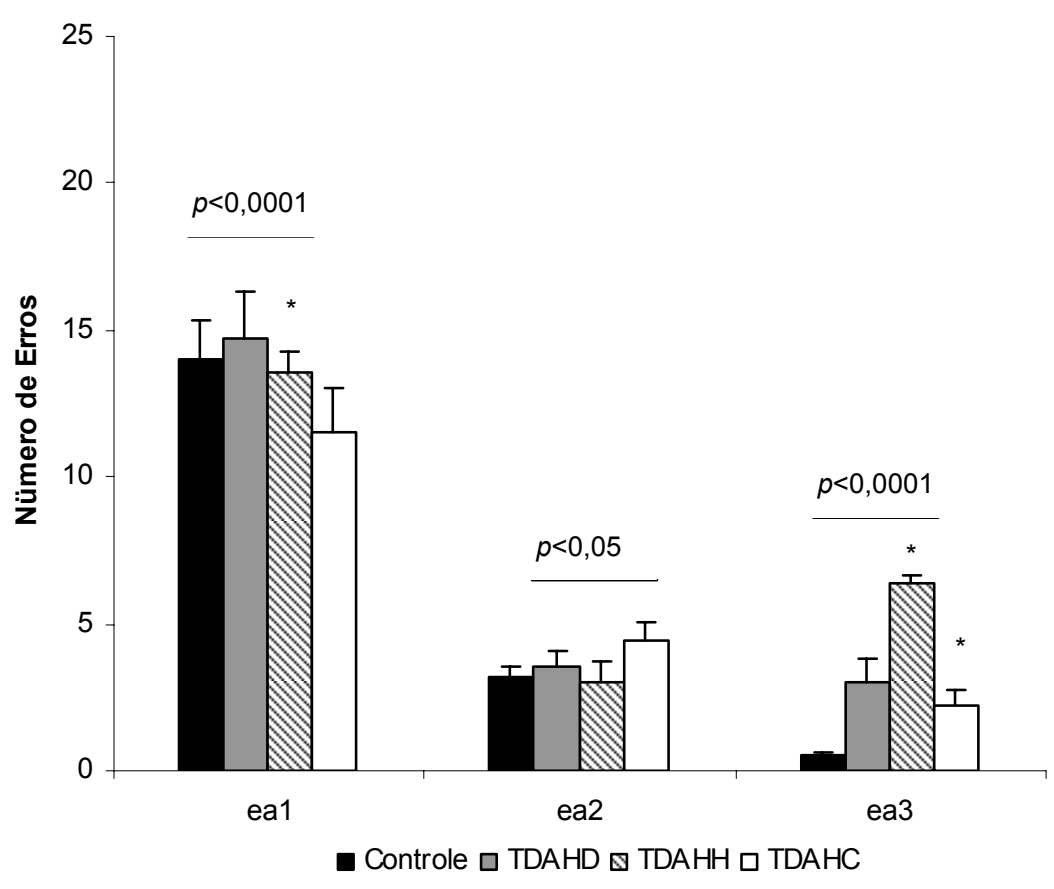

Figura 21. Erros por Ação. Média e erro padrão. ea1: tarefa de atenção seletiva; ea2: tarefa de alternância; ea3: tarefa de atenção sustentada. ${ }^{*} p<0,05$ 


\section{DISCUSSÃO}

Os resultados obtidos neste trabalho com portadores do TDAH demonstraram uma perda significante de desempenho na recordação de itens que foram aprendidos em diferentes condições, quais sejam: categorial seriada, categorial agrupada, não categorial seriada não categorial agrupada. As evidências deste trabalho corroboram a idéia de Cornoldi e colaboradores (1999) de que portadores do TDAH apresentam uma ampla condição de prejuízos cognitivos, incluindo os de memória de longa duração.

O desempenho inferior na recordação dos itens apresentados foi observado na condição seriada não categorial (Figura 6). A ausência de diferenças entre os grupos na condição categorial parece sugere que os portadores do transtorno utilizaram estratégias de recordação organizada, ou seja, evocando um maior número de itens corretos do que na condição que não permitia organização em categorias. Estes dados são contrastantes com a idéia de que portadores do TDAH teriam mais dificuldades para realizar tarefas de memória que recrutassem estratégias de organização da informação (CORNOLDI e colaboradores, 1999; DOUGLAS e BENEZRA, 1990; PENNINGTON e OZANOFF, 2002).

Houve diferença significativa na condição não-categorial para os grupos hiperativo (TDAHH) e combinado (TDAHC) quando comparados com o grupo controle. Esta diferença gerou também uma diferença na comparação entre a tentativa categorial, com figuras com aproximação semântica por classes (e.g., frutas) e a tentativa não categorial (=MLDS). Juntos, estes resultados demonstram que houve prejuízo para dois grupos com TDAH na recordação livre de estímulos quando não são semanticamente relacionados e sugerem a presença de prejuízo na capacidade de memória de longa duração quando se previne o uso de estratégias de organização.

Deve-se considerar que os estímulos eram visuais e nomeáveis. Neste estudo, os portadores do TDAH nos três subtipos não apresentaram diferenças no índice fatorial de organização perceptual (IOP) da Bateria WISC-III (Figura18). De fato, poderse-ia sugerir que o prejuízo de memória visual para os grupos com TDAH fosse proveniente de uma baixa capacidade de organização perceptual. Como não houve 
efeito para o fator IOP, as dificuldades parecem ser dependentes do próprio fator memória, com um prejuízo na evocação após intervalo para a memória visual. Prejuízos na memória visual para evocação de desenhos (GIBNEY e colaboradores, 2002) e memória verbal de longa duração (SLOMINE e colaboradores, 2005), estão presentes em portadores do TDAH.

A ausência de efeito para o fator IOP, não se deu para o índice de QI Executivo (Figura 17). Mas a diferença existente para os grupos foi específica entre os grupos controle e TDAHD. Estes grupos não diferiram nas provas de memória de longa duração seriada categorial e não categorial. Os grupos que não tiveram diferença no Q। Executivo, TDAHH e TDAHC foram os que apresentaram diferenças na média dos escores resultantes do número de evocações corretas dos itens aprendidos. Este fator parece corroborar a idéia de um prejuízo de memória de longa duração (MLD) específico para o TDAH por subtipo. Há evidência de problemas de funcionamento de memória no TDAH sem diferença entre grupos (FARAONE e colaboradores, 1998; CHABILDAS e colaboradores, 2004), mas outros estudos como o de Schmitz e colaboradores (2002), Diamond e colaboradores (2005) sugerem que os subtipos desatento e combinado apresentariam os maiores problemas.

Os resultados para memória de longa duração agrupada (Figura 7) mostraram diferenças nos escores dos três subgrupos e do grupo controle para as condições categorial e não categorial. Os grupos variaram também com uma redução significante na média do número de itens evocados corretamente entre a condição categorial e não categorial, com um prejuízo maior para o grupo TDAHH, que apresentou um menor número de itens evocados. Juntos, estes resultados sugerem que o desempenho de memória de longa duração para portadores de TDAH foi pior do que em não portadores quando as figuras estímulos foram apresentadas agrupadas em uma matriz. O grupo hiperativo teve um pior desempenho nestas tarefas. É possível que a monotonia da tarefa (exposição por um minuto contínuo) tenha reduzido o desempenho do grupo TDAHD, mas os outros grupos também tiveram um desempenho abaixo do grupo controle.

O fator memória de longa duração deve ser aqui cuidadosamente analisado. Aparentemente, os prejuízos no desempenho poderiam se dever à característica da 
tarefa, mas novamente o fator categorial e não categorial foi observado, quando houve uma diferença significativa para os três subtipos de TDAH entre as diferentes apresentações. O prejuízo foi mais substancial quando a condição não categorial foi apresentada para evocação tardia, após o intervalo de 20 minutos. Por outro lado, a apresentação categorial, com figuras semanticamente relacionadas, não preveniu um desempenho inferior para os grupos com TDAH. O racional mais provável é a existência de dificuldades para recordação tardia (memória de longa duração) em portadores do TDAH e que estas dificuldades não são dependentes de estratégias de organização da informação a ser evocada. Por outro lado, Kaplan e colaboradores (1999) referem que as dificuldades de memória no TDAH são insuficientes para serem consideradas como uma queixa central.

Apesar de não se considerar os problemas de memória como queixa central no TDAH, os mesmos estão presentes nos relatos de portadores e familiares (BROWN, 1996). Na presente investigação o autor considerou não apenas a queixa como relevante, como os dados dos resultados de memória de longa duração sugerem um prejuízo na função como uma possível característica do TDAH.

A Figura 10 apresenta dados percentuais do índice de desempenho para a diferença entre a memória de longa duração categorial agrupada e seriada. Naturalmente esperava-se um menor número de itens evocados na condição agrupada. Os resultados sugerem que a diferença foi maior na condição não categorial, indicando que os indivíduos lembraram menos ainda na condição não-categorial agrupada. Diferenças existentes no índice de desempenho entre as condições categorial seriada e agrupada entre os grupos TDAH sugerem que o prejuízo de memória possa não ser dependente de capacidade organizacional. Em contraste, poder-se-ia supor que as falhas na MLD adviriam de prejuízo de memória operacional, que prolonga a representação mental de eventos e é prejudicada no TDAH (BARKLEY, 1997). Houve ausência de diferenças nos índices de memória operacional da bateria WISC-III.

Estes resultados culminaram juntamente com os outros testes da bateria na ausência de diferenças na escala executiva. Além disso, as condições da bateria MEMO foram desenhadas de acordo com o conceito de memória de longa duração, que envolve um a evocação tardia mesmo após um único contato com a experiência 
(Helene e Xavier, 2003)., como no caso das condições agrupadas. Shin e colaboradores (2003) relataram um prejuízo em sujeitos portadores do TDAH, quando comparados com sujeitos saudáveis, para a recordação e capacidade organizacional, utlizando a figura comprlexa de Rey-Osterreith.

Os índices de perda entre a memória de longa duração e a apresentação antes da evocação tardia foram apresentados na Figura 8 para as condições seriadas (categorial e não categorial) e na Figura 9 para as condições agrupadas (categorial e não categorial). Os índices de desempenho evidenciaram perdas mais importantes, ou seja, uma pior recordação dos estímulos apresentação para as condições nãocategorial seriada e agrupada. Houve um efeito de grupo, mas os grupos com TDAH diferiram do grupo controle, com um desempenho marginalmente inferior para o grupo TDAHD. Na condição agrupada, o desempenho foi pior para os participantes com TDAHH e TDAHC. Aparentemente as características da apresentação seriada prejudicaram mais o grupo desatento enquanto a apresentação agrupada teve um efeito maior par aos grupos TDAHH e TDAHC.

Avaliação de funções como atenção e memória parecem ser efetivamente dependentes dos procedimentos e no TDAH as diferentes metodologias aplicadas parecem resultar em caracterização neuropsicológica divergente (KAPLAN e colaboradores, 1999; ROSENTHAL e colaboradores, 2005). Por outro lado os grupos variaram para um pior desempenho na condição não-categorial evidenciando dificuldades para recordação da lista sem o uso de estratégias; na requisição com uso de estratégias não houve diferenças significativas entre os grupos. Os grupos TDAHD, TDAHH e TDAHC mostraram resultados similares com uso de estratégias ao grupo controle.

Um fator extremamente importante ocorreu na apresentação da matriz para aprendizagem nas condições seriada e agrupada. Não houve diferença para os grupos nas condições que envolveram evocação imediata, ou seja, os grupos desempenharam igualmente nestas tarefas. Prejuízos entre a apresentação imediata e tardia foram evidenciados. Qual o racional para justificar esta diferença entre a memória imediata e a memória tardia? Se há recuperação na evocação imediata, deve-se investigar que processo poderia estar prejudicado em relação ao desempeno de memória de longa 
duração (evocação tardia) no TDAH. Mello (2003) demonstrou a aquisição progressiva de estratégias de organização no desenvolvimento entre sete a catorze anos de idade. $\mathrm{Na}$ amostra nesta investigação com TDAH, os participantes foram todos entre 11 e 14 anos, quando estas estratégias devam estar bem desenvolvidas (MELLO e XAVIER, 2005). Um dos objetivos deste estudo foi investigar se as estratégias organizacionais de memorização estariam bem desenvolvidas nos portadores do TDAH.

Problemas com a organização de memória têm sido investigados no TDAH e parecem estar particularmente envolvidos com disfunção do lobo frontal (GRODZINSKY e DIAMOND, 1992). A avaliação de funções do lobo frontal no TDAH, mesmo utilizando instrumentos consolidados como a Figura Complexa de Rey, têm evidenciado inconsistência na presença de déficits organizacionais (BARKLEY e colaboradores, 1992; SHIM e colaboradores, 2003).

De fato, no presente estudo, os grupos não diferiram em provas que recrutaram categorização. Os resultados também não evidenciaram um desempenho inferior para os grupos com TDAH na escala executiva da bateria WISC-III (Figura 17), com exceção do grupo TDAHD. Este grupo teve um desempenho inferior ao do grupo controle apenas na condição seriada categorial, mas similar aos grupos TDAHH e TDAHC nas condições seriada não categorial e nas duas condições agrupadas. Estes resultados sugerem que os portadores do TDAH de onze a catorze anos não apresentaram dificuldades nas habilidades organização, incluindo aquelas que envolvem estratégias mnésicas.

Aparentemente, problemas na codificação, armazenamento ou recuperação da informação adquirida para a memória de longa duração poderiam ser responsáveis pelos problemas no TDAH. Circuitarias cerebrais tipicamente envolvidas nos processos neuroquímicos no TDAH, como o córtex órbito-frontal e o estriado parecem contribuir para a codificação da memória de longa duração (ADDIS e McANDREWS, 2006; KERI, 2003; SUZUKI e colaboradores, 2005; WAGNER e colaboradores, 2005). Utilizando material deste estudo para a avaliação de memória de longa duração foi possível estender evidências de que portadores do TDAH podem ter problemas para memorizar informações (DOUGLAS e BENEZRA, 1990, SHIN e colaboradores, 2003), mas que este prejuízo não seria mais específico para situações em que se requerem a 
associação ou organização da informação (CORNOLDI e colaboradores, 1999). Particularmente, em função da ausência de diferenças significantes nas condições que requereram estratégias mnésicas, há evidências no presente estudo que parecem indicar preservação da codificação em portadores do TDAH. Originalmente, estes dados contribuem para a discussão sobre a memória de longa duração na literatura ao indicar prejuízos específicos por subtipos do TDAH, tanto em condições que recrutam estratégias mnésicas de organização ou associação, quanto naquelas que parecem envolver a recordação livre de itens.

A idéia de que problema específico de memória possa ser uma queixa relevante (BROWN, 1996; GITTEN e colaboradores, 2006) no TDAH é corroborada nesta investigação. Pesquisas neuropsicológicas futuras são necessárias para contribuir para a identificação das etapas e processos da memória que estão prejudicados nos portadores do TDAH.

Em relação à aprendizagem, não foram encontradas diferenças entre os grupos com TDAH e grupo controle. A condição em que houve uma diferença foi na média dos itens evocados na terceira tentativa da apresentação seriada não-categorial, entre o grupo TDAHH e controle. Não foram encontradas diferenças também no desempenho entre os grupos com TDAH dentro das apresentações seriadas (Figuras 12 e 13). Estes resultados indicam que os prejuízos de memória de longa duração não dependeram de falhas no armazenamento inicial dos conteúdos, no caso, os estímulos apresentados em série. Houve, sim, diferenças marginalmente significantes quando comparados os desempenhos para todos eles entre a condição categorial e não categorial. Todos os grupos variaram, mas o grupo com TDAHH apresentou um desempenho marcadamente inferior ao do grupo controle (Figura 16). Schmitz e colaboradores (2002) não encontraram diferenças para o grupo com TDAHH num teste de memória imediata. Os autores consideram que questões metodológicas como homogeneidade e tamanho da amostra possam ter influenciado estes resultados. Efetivamente, no presente estudo, um dos limites é a amostra relativamente reduzida por subtipos do TDAH. Por outro lado, estes dados experimentais sugerem comprometimentos para o subtipo hiperativo.

A literatura tem indicado uma tendência para a presença de perfis neuropsicológicos diferenciados no TDAH (ROHDE e HALPERN, 2004; ROMERO- 
AYUSO e colaboradores, 2006). O presente estudo corrobora e estende a idéia de que - TDAH possa ser caracterizado efetivamente por subtipos neuropsicológicos diferenciados. A existência de perfis neuropsicológicos específicos deve ser considerada à luz das alterações sutis entre os subgrupos.

Uma das questões desta investigação é se o tipo de apresentação seriada, ou agrupada, teria efeitos sobre a aprendizagem dos portadores do TDAH. Não foram encontradas diferenças entre os grupos TDAH e controle na primeira apresentação seriada e na apresentação agrupada. Cornoldi e colaboradores (1999) demonstraram que portadores do TDAH melhoram o desempenho com o uso de estratégias de memória se recebem ajuda externa para realizarem categorização. Durante a aplicação dos instrumentos neste estudo, os portadores de TDAH referiram na condição categorial, ao serem questionados sobre possíveis estratégias organizacionais de memória, a identificação na primeira apresentação seriada e na apresentação agrupada, da possibilidade de recordação dos estímulos por categorias. Estas habilidades se desenvolvem progressivamente até os 12 anos (MELLO, 2003). É possível que diferenças na idade entre os grupos possam ter interferido sobre o uso de estratégias organizacionais e igualado assim, a média dos escores nas duas diferentes apresentações. Neste estudo, a idade dos participantes foi um pouco maior do que no de Cornoldi e colaboradores (1999), com uma diferença de seis meses.

A aprendizagem nas condições agrupadas categorial e não categorial mostrou diferenças quando comparados os desempenhos entre os grupos. Os grupos com TDAH tiveram um desempenho inferior ao grupo controle na condição categorial e na condição não categorial, os grupos TDAHH e TDAHC mostraram diferenças do desempenho normal. O grupo TDAHH teve o pior desempenho nesta tarefa (Figura 15). É possível que falhas na manutenção da atenção por longo tempo em função das características do teste possam ter produzido um efeito de redução da quantidade de informações que pôde ser recuperada pelos grupos que tem a hiperatividade como conteúdo ativo do transtorno.

A tendência a cometer erros de julgamento e abandono da tarefa é conhecida nestes indivíduos (BARKLEY, 2002; PISTOIA e colaboradores, 2004; ROHDE e colaboradores, 1999b). A interferência de fatores comportamentais sobre a 
aprendizagem deve ser considerada. Embora não haja uma condição específica de transtorno de aprendizagem, abandono de tarefas, baixo nível de sustentação da atenção e focalização reduzida terminam por gerar efeitos sobre a possível recordação de conteúdo, no mínimo, na quantidade de informação evocada.

A análise de inteligência dos grupos TDAH e controle não mostrou diferenças entre os grupos com TDAH. Todos os grupos com TDAH apresentaram um QI Verbal e Total inferior ao do grupo controle. Não houve, por outro lado, diferenças no QI executivo entre os grupos. Há de se considerar a composição dos grupos como uma forma de observar o desempenho nos testes de QI. Habilidades executivas são tipicamente menores em meninas (SEIDMAN e colaboradores, 2006). O grupo controle foi formado em sua maioria por meninas, enquanto o grupo TDAH foi substancialmente formado por meninos. Estas diferenças podem ter aproximado os escores dos grupos nos testes executivos. Como diferenças neurobiológicas e clínicas entre meninas e meninos parecem ser sutis no TDAH (BIEDERMAN e colaboradores, 2002), o presente estudo não avaliou diferenças entre os sexos. Por outro lado, deve ser considerado que os resultados da escala executiva da bateria WISC-III (Weschler e Figueiredo, 2000) possam ter alcançado similaridade entre os grupos por essa variável. Um fator importante é que os grupos apresentaram um desempenho similar, mas todos dentro de um desempenho médio normal (90-110). A ausência de fatores como o retardo mental é critério diagnóstico para o TDAH. A homogeneidade de inteligência entre os grupos serviu como suporte para a investigação dos fatores relativos à memória, objetivo principal da pesquisa desenvolvida.

Os índices fatoriais da bateria WISC-III revelaram também que o prejuízo foi comum a todos os grupos. Embora o desempenho tenha variado nos índices de Compreensão Verbal (ICV), Resistência à Distração (IRD) e Velocidade de Processamento (IVP), os escores não se diferenciaram entre os grupos TDAH. O mesmo ocorreu com o índice de organização perceptual (IOP), mas sem diferenças com o grupo controle, que teve um desempenho reduzido para este índice. A discussão sobre diferenças entre os sexos acima pode ser aplicada também para a ausência de diferenças entre os grupos TDAH e controle. Há de se observar na Figura 18, um desempenho mais baixo para o grupo TDAHH. Esse desempenho pode ter sido 
explicado por algumas características de estímulo cognitivo. Interessantemente, entre o grupo TDAHH o nível sócio-econômico foi o menor(Tabela 1), onde fatores de queixas comportamentais e escolares são aliadas a uma redução na estimulação cognitiva (Carvalho, 2004).

Os testes atencionais que compõem a bateria TAVIS-3 (DUSCHENE e MATTOS, 1997; COUTINHO e colaboradores, 2006) mostraram diferenças entre os subtipos do TDAH no tempo de reação na prova de atenção seletiva e sustentada. Todos os grupos TDAH tiveram um desempenho inferior ao do grupo controle. O prejuízo maior foi característico do grupo tipo combinado, que apresentou um maior tempo de reação. Coutinho e colaboradores (2007) encontraram um desempenho prejudicado para os grupos com TDAH utilzando o mesmo instrumento, TAVIS-3, para um grupo combinado. Nlgg $(1999,2002)$ encontrou prejuízos maiores também numa tarefa de tempo de reação a um sinal de parada. Mirsky (1987) aponta para a importância deste índice como um dos indicadores de dificuldades de atenção.

O desempenho dos grupos quanto aos erros de omissão nas tarefas de atenção seletiva, alternância e atenção sustentada da bateria TAVIS-3 mostrou uma variação importante. O grupo TDAHH mostrou o melhor desempenho com menos erros por omissão, inclusive em relação ao grupo controle, mas não em relação aos outros dois grupos, TDAHD e TDAHC. Na tarefa de alternância este perfil se mantém. Na tarefa de atenção sustentada observa-se um número de erros significativamente maior para o grupo TDAHD. É possível que a explicação para este desempenho seja dependente de um melhor desempenho no tempo de reação em detrimento de um maior número de erros por omissão.

Nigg e Casey (2005) indicam a importância de avaliação destes escores como referência para disfunções atencionais. Este estudo estende a idéia de que em tarefas de desempenho contínuo, a análise do tempo de reação possa ser característica neuropsicológica específica de subtipos do TDAH (van der Meere, 1996. Este estudo contrapõe-se a achados de Coutinho e colaboradores (2007) com uma amostra não clínica. A amostra deste estudo, com característica clínica, pode contribuir para as discussões sobre os perfis neuropsicológicos diferenciados. 
O número de erros por ação nas três provas seguiu o perfil do número de erros por omissão. Entretanto, juntamente com um número de erros por ação significativamente maior na tarefa de atenção sustentada, que é uma tarefa de desempenho contínuo (contínuos performance task), houve, além do grupo TDAHH, um número de erros marginalmente significantes para o grupo TDAHC. Erros por ação são característicos para pacientes com TDAH em tarefas contínuas e parecem sugerir problemas de inibição de resposta (BARKLEY, 1997). Estes dados dão suporte a estudos com subtipos do TDAH em tarefas de desempenho contínuo (COUTINHO e colaboradores, 2006a, COUTINHO e colaboradores, 2007) e os estendem, ao encontrar diferenças em erros de ação no desempenho em tarefas de desempenho contínuo em portadores do TDAH do tipo hiperativo. 


\section{CONCLUSÕES}

O presente trabalho permitiu as seguintes conclusões:

* Portadores do Transtorno do Déficit de Atenção e Hiperatividade, de 11 a 14 anos de idade apresentam prejuízos de memória de longa duração.

* O desempenho inferior na memória de longa duração ocorreu tanto em condição categorial, quando é possível o uso de recursos de organização de memória, quanto em condição não categorial, quando o registro é realizado por unidades. O prejuízo na memória de longa duração foi independente de prejuízos nas habilidades de organização de memória.

* Os três subtipos do transtorno: desatento, hiperativo e combinado obtiveram perfil neuropsicológico diferenciado em testes de memória de longa duração.

* O desempenho na recordação de estímulos com apresentação seriada foi mais prejudicado na condição não categorial, principalmente para os grupos hiperativo e combinado.

* Portadores dos três subtipos do transtorno apresentaram um desempenho inferior em relação aos participantes normais na memória de longa duração, quando os estímulos foram apresentados agrupados, principalmente na condição não categorial.

* Adolescentes portadores do transtorno não apresentaram falhas no uso de recursos mnésicos.

* Portadores do subtipo hiperativo mostraram um pior desempenho na aprendizagem.

- Prejuízos nas funções atencionais foram apresentados pelos três sutipos: o tipo combinado teve o pior desempenho no tempo de reação; os de predomínio hiperativo e combinado o pior desempenho nos erros por 
ação, que indicam desatenção; o subtipo hiperativo o pior desempenho em erros por omissão. 


\section{REFERÊNCIAS BIBLIOGRÁFICAS}

ADDIS, D.R.; McANDREWS, M.P. Prefrontal and hippocampal contributions to the generation and binding of semantic associations during successful encoding. Neuroimage. London, v.33, p. 1194-1206, 2006.

ALVAREZ, J.A.; FREIDES, D. Research on attention déficit hyperactivity disorder using the covert orienting paradigm of Posner. Developmental Neuropsychology. Louisville, v. 26, p. 627-645, 2004.

ALYWARD, G.P.; GORDON, M.; VEHULST, S.J. Relationships between continuous performance task scores and other cognitive measures: causality or commonality? Assessment. Kent, v. 4, p. 313-24, 1997.

AMERICAN PSYCHIATRIC ASSOCIATION. Diagnostic and Statiscal Manual of Mental Disorders. Ed.3. APA, Washington: , DC, $1980 .$.

AMERICAN PSYCHIATRIC ASSOCIATION. Manual diagnóstico e estatístico de transtornos mentais. Ed.4. Porto Alegre: Artes Médicas, 1994. 845p.

ARAÚJO, A. Avaliação e manejo da criança com dificuldade escolar e distúrbio de atenção. Jornal de Pediatria. Porto Alegre, v.78, p.104-110, 2002.

ARNSTEN AF. Fundamentals of attention-deficit/hyperactivity disorder: circuits and pathways. Journal of Clinical Psychiatry. Tucson, v.67, p.7-12, 2006.

BADDELEY, A. Working memory and language: an overview. Journal of Communication Disorders. Toronto, v.36, p.189-208, 2003.

BADDELEY, A. The episodic buffer: a new component of working memory? Trends in Cognitive Sciences. London, v.4, p.417-423, 2000.

BADDELEY, A; HITCH G.J. Working memory. In: Bower, G. (Ed.). The psychology of learning and motivation. New York: Academic Press, p.47-90, 1974.

BARBOSA, G.A. ranstornos hipercinéticos. Infanto. São Paulo, v. 2, p. 12-19, 1995.

BARKLEY, R. Transtorno do Déficit de Atenção/Hiperatividade. Porto Alegre: Artmed , 2002a. 328 p.

BARKLEY, R.A.; FISCHER, M.; SMALLIS, L.; FLETCHER, K. The persistence of attention-deficit/hyperactivity disorder into young adulthood as a function of reporting source and definition of disorder. Journal of Abnormal Psychology. lowa City, v.111, n.2, p.279-289, 2002b. 
behavior: three-year outcome as a function of adaptive disability. Development and Psychopathology. Minneapolis ,v.14, p.45-67, 2002c.

BARKLEY, R.A.; EDWARDS, G.; LANERI, M.; FLETCHER, K. Executive functioning, temporal discounting, and sense of time in adolescents with attention deficit hyperactivity disorder (ADHD) and oppositional defiant disorder (ODD). Journal of Abnormal Child Psychology. Tuscaloosa, v.29, p.541-556, 2001.

BARKLEY, R. Behavioural inhibition, sustained attention and executive functions: constructing a unifying theory of ADHD. Psychological Bulletin. Durham, v.121, p.6594, 1997.

BARKLEY, R.A. Linkages between attention and executive functions. In: LYON, R.G.; KRASNEGOR, N.A. (Eds). Attention, memory and executive function. Baltimore: Paul H. Brookes Publishing, p.307-326.1996.

BARKLEY, R.A.; GRODIZINSKY, G.; DU PAUL, G.J. Frontal lobe functions in attention disorder with and without hyperacitivity. Journal of abnormal child psychology. Tuscaloosa, v. 20, p. 163-188, 1992.

BELMONT, J.;BORKOWSKI, J.G. A group test of children's metamemorial knowledge. Bulletin of the Psychonomic Society. Austin, v.26, p.206-209, 1988.

BENZICK, E. B.P. Manual da Escala de Transtorno de Déficit de Atenção/Hiperatividade: Versão para professores. São Paulo: Casa do Psicólogo, 2000. 64p.

BIEDERMAN, J.; MICK, E.; FARAONE, S.V.; BRAATEN, E.; DOYLE, A.; SPENCER, T; WILENS, T.E.; FRAZIER, E.; JOHNSON, M.A. Influence of gender on attention deficit hyperactivity disorder in children referred to a psychiatric clinic. American Journal of Psychiatry. Arlington, v.159, p.36-42, 2002.

BIEDERMAN, J.; MICK, E.; FARAONE, S.V. Age-dependent decline of symptoms of attention deficit hyperactivity disorder: impact of remission definition and symptom Type. American Journal of Psychiatry. Arlington, v.157, p.816-818, 2000.

BIEDERMAN, J.; FARAONE, S.V; MICK, E. Clinical correlates of ADHD in females: findings from a large group of girls ascertained from pediatric and psychiatric referral sources. Journal of the American Academy of Child and Adolescent Psychiatry. Chicago, v. 38, p.966-967, 1999.

BIEDERMAN, J.; MILGERGER, S.; FARAONE, S.V.; KIELY, K.; MICK, E. et al. Familyenvironment risk factors for ADHD: a test of Rutter's indicators of adversity. Archives of General Psychiatry. Belmont, v.52, p.464-470, 1995.

BOUSFIELD, W.A. The occurrence of clustering in the recall of randomly arranged associates. Journal of General Psychology. Grand Forks, v.49, p.229-240, 1953. 
BROCKI, K.C.; BOHLIN, G. Executive functions in children aged 6 to 13: a dimensional and developmental study. Developmental Neuropsychology. Lousville, v.26, p.571593, 2004.

BROWN, T.E. Brown Attention-Deficit Disorder Scales. The Manual. San Antonio: The Psychological Corporation, 1996.

BYRNE, J.M. Attention déficits: neuropsychological dimensions: introduction and overview. Child Neuropsychology. New Haven, v.4, p.3-6, 1998.

CANTWELL, D.P. Attention deficit disorder: a review of the past 10 years. Journal of the American Academy of Child and Adolescent Psychiatry. Chicago, v.8, p.978987, 1996.

CAPDEVILA-BROPHY, C.; ARTIGAS-PALLARES, J.; RAMIREZ-MALLAFRE, A.; LOPEZ-ROSENDO, M.; REAL, J.; OBIOLS-LLANDRICH, J.E. The neuropsychological phenotype of attention deficit hyperactivity disorder:are there differences among subtypes? Revista de Neurología. Barcelona, v.40, p.17-23, 2005.

CARLSON, C.L.; MANN, M. Sluggish cognitive tempo predicts a different pattern of impairment in the attention decifit hyperactivity disorder, predominantly inattentive type. Journal of Clinical Child and Adolescent Psychology. New Orleans, v.31, p.123-129, 2002.

CARLSON, C.L.; PELHAM, W.E. JR; SWANSON, J.M.; WAGNER J,L. A divided attention analysis of the effects of methylphenidate on the arithmetic performance Journal of the American Academy of Child and Adolescent Psychiatry. Chicago, v. 32, p. 463-71, 1991.

CARVALHO, M. P. Quem são os meninos que fracassam na escola? Cadernos de Pesquisa. São Paulo, v 34, p.11-40, 2004.

CASEY, B.; FORMAN, S.; FRANZEN, P.; BERKOWITZ, A.; BRAVER, T.; NYSTROM, L.; THOMAS, K.; NOLL, D. Sensitivity of prefrontal cortex to changes in target probability: a functional MRI study. Human Brain Mapping. San Antonio, v. 13, p.26-33, 2001.

CASTELLANOS, F.X.; LEE, P.P.; SHARP, W.; JEFFRIES, N.O.; GREENSTEIN, D.K.; CLASEN, L.S.; BLUMENTHAL, J.D.; JAMES, R.S.; EBENS, C.L.; WALTER, J.M.; ZIJDENBOS, A.; EVANS, A.C.; GIEDD, J.N.; RAPOPORT J.L. Developmental trajectories of brain volume abnormalities in children andadolescents with attentiondeficit/hyperactivity disorder. The Journal of American Medical Association. Chicago, v.288, p.1740-1748, 2002. 
CEPEDA, N.J.; CEPEDA, M.L.; KRAMER, A.F. Task switching and attention defict hyperactivity disorder. Journal of Abnormal Child Psychology. Tuscaloosa, v.28, p.213-226, 2000.

CHABILDAS, N.; PENNINGTON, B.F.; WILLCUTT, E.G. A comparison of the neuropsychological profiles of the DSM-IV subtypes of ADHD. Journal Abnormal Child Psychology. Tuscaloosa, v.29, p.529-540, 2001.

CONWAY, A.R.A.; TUHOLSKI, S.W.; SHISLER, R.J.; ENGLE, R. T he effect of memory load on negative priming: an individual differences investigation. Memory and Cognition. Urbana-Champaign, v.27, p.1042-1050, 1999.

CORKUM P.V.; SIEGEL, L.S. Is the continuous performance task a valuable research tool for use with children with attention-deficit-hyperacitivity disorder? Journal of Child Psychology and Psychiatry. London, v.34, p.1217-1239, 1993.

CORNOLDI, C.; BARBIERI, A.; GAIANI C.; ZOCCHI, S. Strategic memory déficits in attention defici disorder with hyperactivity participants: the role of executive process. Developmental Neuropsychology. Lousville, v.15, p.53-71, 1999.

COUTINHO, G.C.; MATTOS, P.; BASTOS, C.C.A.Q.; DUSCHENE, M. Transtorno do Déficit de Atenção e Hiperatividade: Contribuição Diagnóstica de Avaliação Computadorizada de Atenção Visual. No prelo. Revista de Psiquiatria Clínica. São Paulo, 2007a.

COUTINHO, G; MATTOS, P; ARAUJO, C. Desempenho neuropsicológico de tipos de transtorno do déficit de atenção e hiperatividade (TDAH) em tarefas de atenção visual. Jornal Brasileiro de Psiquiatria. São Paulo, v.56, p.13-16, 2007b.

CRUZ, R. M.; ALCHIERI, J.C.; SARDA JR. Avaliação e medidas psicológicas: produção do conhecimento e da intervenção profissional. São Paulo: Casa do Psicólogo, 2002. 128p.

DIAMOND, A. Attention-deficit disorder: a neurobiologically and behaviorally distinct disorder from attention-deficit/hyperactivity disorder. Development and Psychopathology. Minneapolis, v.17, p.807-825, 2005.

DOUGHERTY DD, BONAB AA, SPENCER TJ, RAUCH SL, MADRAS BK, FISCHMAN AJ. Dopamine transporter density in patients with attention deficit hyperactivity disorder. The Lancet. London, v.354, p.2132-2133, 1999.

DOUGLAS, V.I.; BENEZRA, E. Supraspan verbal memory in attention deficit disorder with hyperactivity normal and reading-disabled boys. Journal of Abnormal Child Psychology. Tuscaloosa, v.18, p.617-638, 1990.

DUCHESNE, M.; MATTOS, P. Normatização de um teste computadorizado de atenção visual (TAVIS). Arquivos de Neuropsiquiatria. São Paulo, v.55, p.62-69, 1997. 
DURSTON, S.; FOSSELLA, J.A.; CASEY, B.J.; HULSHOFF POL, H,E., GALVAN, A., SCHNACK, H.G.; STEENHUIS, M.P.; MINDERAA, R.B.; BUITELAAR, J.K.; KAHN, R.S.; VAN ENGELAND, H. Differential effects of DRD4 and DAT1 genotype on frontostriatal gray matter volumes in a sample of subjects with attention deficit hyperactivity disorder, their unaffected siblings, and controls. Molecular Psychiatry. Miami, v. 10, p. 678-85, 2005.

FARAONE, SV; SERGEANT, J; GILBERG, C; BIEDERMAN, J. The worldwide prevalence of ADHD: is it an American condition? World Psychiatry. Geneva, v.2, p.104-113, 2003.

FARAONE SV, BIEDERMAN J, WEBER W, RUSSELL RL. Psychiatric, neuropsychological, and psychosocial features of DSM-IV subtypes of attentiondeficit/hyperactivity disorder: results from a clinically referred sample. Journal of the American Academy of Child and Adolescent Psychiatry. Chicago, v.37, p.185-193, 1998.

FISCHER, M.; BARKLEY,R .; SMALLISH, L.; FLETCHER, K. Executive functioning in hyperactive children as young adults: attention, inhibition, response perserveration, an the impact of comorbidity. Developmental Neuropsychology. Lousville, v.27, p.107133, 2005.

FOLEY NICPON, M.; WODRICH, D.L., ROBINSON KURPIUS, S.E. Utilization behavior in boys with ADHD: a test of Barkley's theory. Develpmental Neuropsychology. Lousville, v.26, p.735-751, 2004.

FROST, R.; BENTIN, S. Processing phonological and semantic ambiguity: evidence from semantic priming at different SOAs. Journal of Experimental Psycholoby: Learning, Memory and Cognition. v. 18:58-68, 1992.

FUGGETTA, G.P. Impairment of executive functions in boys with attention deficit/hyperactivity disorder. Child Neuropsychology. New Haven, v.12, p.1-21, 2006.

GIBNEY, L.A.; MCINTOSH, D.E.; DEAN, R.S.; DUNHAM, M. Diagnosing attention disorders with measures of neurocognitive functioning. International Journal of Neuroscience, Chapel Hill, v.112, p.539-564, 2002.

GITTEN, J.C.; WINER, J.L.; FESTA, E.K.; WILLIAM C.; HEINDEL, W.C. Conditional Associative Learning of Spatial and Object Information in Children with Attention Deficit/Hyperactivity Disorder. Child Neuropsychology. New Haven, v. 12, p.39-56, 2006.

GOLFETO, J.H; BARBOSA, G.A. Epidemiologia. In: ROHDE, L.A.; MATTOS, P.. Princípios e práticas em TDAH: transtorno do deficit de atenção/hiperatividade. Porto Alegre: Artmed, p.15-33, 2003. 
GRODIZINSKY, GM; DIAMOND, R. Frontal lobe dysfunction in boys with attentiondeficit hyperactiviy disorder. Developmental Nueopsychology, Lousville, v. 8, p. 427445, 1992.

GUARDIOLA, A. Distúrbio de hiperatividade com déficit de atenção: um estudo de prevalência e fatores associados em escolares de $1^{\text {a }}$ série de Porto Alegre. 1994. Porto Alegre: Universidade Federal do Rio Grande do Sul. (Tese Doutorado).

GUARDIOLA, A.; FUCHS, F.D.; ROTTA, N.T. Prevalence of attention-deficit hyperactivity disorders in students: comparison between DSM-IV and neuropsychological criteria. Arquivos de Neuropsiquiatria. São Paulo, v.58, p.401407, 2000.

HALE, J.B; HOEPPNER, J.B.; FIORELLO, C.A. Analyzing digi span component for assessment of attention processes. Journal of Psychoeducational Asssessment. Calgary, v.20, p.128-143, 2002.

HALE, S.; BRONIK, M.D.; FRY, A.F. Verbal and spatial working memory in school-age children: developmental differences in susceptibility to interference. Developmental Psychology. Providence, v.33, p.364-371, 1997.

HELENE, A.F.; XAVIER, G.F. A construção da atenção a partir da memória. Revista Brasileira de Psiquiatria. São Paulo, v.25, p.12-20, 2003.

HERVEY, A.S.; EPSTEIN, J.N.; CURRY, J.F. Neuropsychology of adults with attentiondeficit/hyperactivity disorder: a meta-analytic review. Neuropsychology. Cleveland, v.18, p.485-503, 2004.

HOMER, C.J.; BALTZ, R.D.; HICKSON, G.B. et al. Clinical practice guideline: diagnosis and evaluation of the child with attention-deficit/hyperactivity disorder. Pediatrics. Burlington, n.105, p.1158-1170. 2000

HUFFMAN, K.; VERNOY, M.; VERNOY, J. Memória. In: HUFFMAN, K.; VERNOY, M.; VERNOY, J. Psicologia. São Paulo: Atlas, p.231-267, 2003.

KANE, M.J.; ENGLE, R.W. The role of the prefrontal cortex in working-memory capacity, executive attention and general fluid intelligence: an individual-differences perspectiva. Pscyhonomic Bulletin \& Review. Austin, v.9, p.637-671, 2002.

KANE, M.J.; BLECKLEY, M. CONWAY, A.R. ; ENGLE, R.W. A controlled-attention view of working-memory capacity. Journal of Experimental Psychology: General. Washington, v.130, p.169-183, 2001.

KANE, M.J.; ENGLE, R.W. Working-memory capacity, proactive interferente, and divided attention: limits on long-term memory retrieval. Journal of Experimental Psychology. Washington, v.26, p.336-358, 2000. 
KAPLAN, B.J.; DEWEY, D.; CRAWFORD, S.G.; FISHER, G.C. Deficits in long-term memory are not characteristic of ADHD. Journal of Clinical and Experimental Neuropsychology. London, v.20, p.518-528, 1998.

KERI, S. The cognitive neuroscience of category learning. Behavioral Brain Research. Ann Harbor., v.43, p.85-109, 2003.

KERNS, K.A.; PRICE, J.J. An investigation of prospective memory in children with ADHD. Child Neuropsychology. New Haven, v.7, p.162-171, 2001.

KING, J.A.; BARKLEY, R.,A.; BARRETT, S. Attention-deficit hyperactivity disorder and the stress response. Biological Psychiatry. West Haven, v.44, p.72-74, 1998.

KONRAD, K.; NEUFANG, S.; HANISCH, C.; FINK, G.R.; HERPERTZ-DAHLMANN, B. Dysfunctional attentional networks in children with attention deficit-hyperacitivity disorder: Evidence from an event-related functional magnetic resonance imaging study. Biological Psychiatry. West Haven, v.59, p.643-651, 2006.

KORKMAN, M.; PESONEN, A.E. A comparison of neuropsychological test profiles of children with attention deficit-hyperactivity disorder and/or learning disorder. Journal of Learning Disabilities. Austin, v.27, p.383-392, 1994.

KOURAKIS, I.E.; KATACHANAKIS, C.N.; VLAHONIKOLIS, I.G.; PARITSIS, N.K. Examination of verbal memory and recall time in children with attention deficit hyperactivity disorder. Developmental Neuropsychology. Lousville, v.26, p.565-570, 2004.

KRAMER, A.F.; CEPEDA, N.J.; CEPEDA, M.L. Methylphenidate effects on taskswitching performance in attention-deficit/hyperactivity disorder. Journal of the American Academy of Child and Adolescent Psychiatry. Chicago, v.40, p.12771284, 2001.

KRAUSE, K.H.; DRESEL, S.H.; KRAUSE, J.; KUNG, H.F.; TATSCH, K. Increased striatal dopamine transporter in adult patients with attention deficit hyperactivity disorder: effects of methylphenidate as measured by single photon emission computed tomography. Neuroscience Letters. San Diego, v.285, p.107-110, 2000.

KUNTSI, J.; STEVENSON, J. Hiperactivity in children: a focus on genetic research and psychological theories. Clinical Child and Family Psychology Review. Columbia, v.3, p.1-23, 2000.

LABAR, K.S.; GITELMAN, D.R.; PARRISH, T.B.; MESULAM, M. Neuroanatomic overla of working memory and spatial attention networks: a functional MRI comparison within subjects. Neuroimage. London, v.10, p.695-704, 1999.

LEVIN, H.S.; CULHANE, K.A.; HARTMAN, J.; EVANKOVICH, K.; MATTSON, A.J.; HARWARD, H.; RINGHOLTZ, G.; EWING-COBBS, L.; FLETCHER, J.M. 
Developemental changes in performance ontests of pore ported frontal lobe fuctining. Developmental Neuropsychology. Lousville, v.7, p.377-395, 1991.

LOGAN, G. D. On the ability to inhibit thought and action: Ausers' guide to the stop signal paradigm. In: DAGENBACH, D.; CARR, T. H. (Eds.). Inhibitory processes in attention, memory, and language. San Diego: Academic Press, p.189-239, 1994.

LOWE, N; KIRLEY, A; HAWI, Z; SHAM, P; WICKHAM, H; KRATOCHVIL, CJ; SMITH, SD; LEE, SY; LEVY, F; KENT, L; MIDDLE, F; ROHDE, LA; ROMAN, T; TAHIR, E; YAZGAN, Y; ASHERSON, P; MILL, J; THAPAR, A; PAYTON, A; TODD, RD; STEPHENS, T; EBSTEIN, RP; MANOR, I; BARR, CL; WIGG, KG; SINKE, RJ; BUITELAAR, JK; SMALLEY, SL; NELSON, SF; BIEDERMAN, J; FARAONE, SV; GILL, $M$. Joint analysis of the DRD5 marker concludes association with attentiondeficit/hyperactivity disorder confined to the predominantly inattentive and combined subtypes. The American Journal Human Genetics. Boston, v. 74, p. 348-56, 2004.

MacDonald VM, Achenbach TM. Attention problems versus conduct problems as sixyear predictors of problemscores in a national sample Journal of the American Academy of Child and Adolescent Psychiatry. Chicago, v. 35, p. 1237-46, 1996.

MATTOS, P.; PALMINI, A.; SALGADO, C.A.; SEGENREICH, D; GREVET, E.; OLIVEIRA, I.R.; ROHDE, L.A.; ROMANO, M.; LOUZÃ, M.; ABREU, P.B.; LIMA, P.P. Painel brasileiro de especialistas sobre diagnóstico do transtorno do déficit de atenção/hiperatividade (TDAH) em adultos. Revista de Psiquiatria do Rio Grande do Sul. Porto Alegre, v.28, n.2, p.50-60, $2006 a$.

MATTOS, P.; SERRA-PINHEIRO, M.A.; ROHDE, L.A.; PINTO D. . A Brazilian version of the MTA-SNAP-IV for evaluation of symptoms of attention-deficit/hyperactivity disorder and oppositional-defiant disorder. Revista de Psiquiatria do Rio Grande do Sul , Porto Alegre, v. 28, n. 3, p. 290-297,2006b.

MATTOS, P.; KAEFER, H.; KNIJNIK, M.P.; SONCINI, N. Neuropsicologia do TDAH. In: ROHDE, L.A.; MATTOS, P. Princípios e práticas em TDAH: Transtorno do deficit de atenção/hiperatividade. Porto Alegre: Artmed, p.63-73. 2003.

MATTOS, P. (2001) No Mundo da Lua: Perguntas e respostas sobre Transtorno de Déficit de Atenção com Hiperatividade em crianças, adolescentes e adultos. São Paulo: Lemos Editorial, 2001. 167p.

MELLO, C.B.; XAVIER, G.F. Desenvolvimento da memória: influencias do conhecimento de base e do uso de estratégias. In: MELLO, C.B.; MIRANDA, M.C.; MUSZKAT, M. Neuropsicologia do desenvolvimento: conceitos e abordagens. São Paulo, Memnon, p.106-126, 2005.

MELLO, C.B. Formação de conceitos e estratégias de memória em crianças de sete a quatorze anos de idade [tese]. São Paulo: USP; 2003. 
MELLO, C.B.; ABREU, J.N.S. MEMO: Teste de memória categoria. Versão Experimental. São Paulo, 2000.

MIRSKY, A.F. Behavioral and psychophysiological markers of disordered attention. Environmental health perspectives. Washington, v.74, p.191-199, 1987.

NAKAI, T.; KATO, C.; MATSUO K. An FMRI study to investigate auditory attention: a model of the cocktail party phenomenon. Magnetic Resonance in Medical Science. Tokyo, v.4, p.75-82, 2005.

NARBONA, J.; CRESPO-EGUÍLAZ. Transtornos de memoria y de atención en disfunciones cerebrales del niño. Revista de Neurología. Barcelona, v. 40, S33-s36.

NEISSER, U.; BECKLEN, R. Selective looking: attending to visually specified events. Cognitive Psyhology. Philadelphia, v.7, p.480-494, 1975.

NIGG, J.T., CASEY B.J. An integrative theory of attention-deficit/hyperactivity disorder based on the cognitive and affective neurosciences. Development and Psychopathology. Minneapolis, v.17, p.785-806, 2005.

NIGG, J.T.; BLASKEY, L.G.; HUANG-POLLOCK, C.L.; RAPPLEY, M.D. Neuropsychological Executive Functions and DSM-IV ADHD Subtypes. Journal of America Academy of Child and Adolescence Psychiatry. Chicago v. 41, p. 59-66, 2002.

NIGG, J.T. Is ADHD an inhibitory disorder? Psychological Bulletin. Durham, v 127, p.571-598, 2001.

NIGG, J.T. The ADHD response-inhibition deficit as measured by the stop task: replication with DSM-IV combined type, extension, and qualification. Journal of Abnormal Child Psychology. Tuscaloosa, v.27, p.393-402, 1999.

NIGG, J.T.; SWANSON, J.M.; HINSHAW, S.P. Covert visual spatial attention in boys with attention deficit hyperactivity disorder: lateral effects, methylphenidate response and results for parents. Neuropsychologia. Manchester, v.35, p.165-176, 1997.

O'NEIL, M.E.; DOUGLAS, V.I. Study strategies and story recall in attention deficit disorder and reading disability. Journal of Abnormal Child Psychology. Tuscaloosa, v.19, p. 671-692, 1991.

ØIE M, RUND BR. Neuropsychological déficits in adolescent-onset Schizophrenia compared with ADHD. American Journal of Psychiatry. Arlington, v.156: p.1216-1222, 1999. 
ORGANIZAÇÃO MUNDIAL DA SAÚDE. Manual da classificação internacional de doenças, lesões e causas de óbito. Rev.9. 1975. São Paulo, Centro Brasileiro para a Classificação de Doenças, 1978.

OTT, D.A.; LYMAN, R.D. Automatic and Effortful Memory in Children Exhibiting Attention-Deficit Hyperactivity Disorder. Journal of Clinical Child Psychology (Journal of Clinical Child and Adolescent Psychology). New Orleans, v.22, p.420427, 1993.

PASHLER, H. Dual-task interference in simple tasks: data and theory. Psychological Bulletin. Durham, v.116, p.220-244, 1994.

PASTURA, G.M.C.; MATTOS, P.; ARAÚJO, A.P.Q.C. Desempenho escolar e Transtorno do Déficit de Atenção e Hiperatividade. Revista de Psiquiatria Clínica. São Paulo, v.32, p.324-329, 2005.

PENNINGTON, B.F. Toward a new neuropsychological model of attentiondeficit/hyperactivity disorder: subtypes and multiple deficits. Biological Psychiatry. West Haven, v.57, p.1221-1223., 2005.

PENNINGTON B.F.; OZONOFF S. Executive functions and developmental psychopathology. Journal of Child Psychology and Psychiatry. London, v.37, p.5187, 1996.

PISTOIA, M.; ABAD-MAS, L.; ETCHEPAREBORDA, M.C. Abordaje psicopedagógico del trastorno por déficit de atención con hiperactividad con el modelo de entrenamiento de las funciones ejecutivas. Revista de Neurología. Barcelona, v.38, p.149-155, 2004.

QUAY, H.C. Inhibition and attention deficit hyperactivity disorder. Journal of Abnormal Child Psychology. Tuscaloosa, v.25 ,p.7-13, 1997.

REYNODS, C.R. Forward and backward memory span shoud not be combined for clinical analyses. Archives of Clinical Neuropsychology. Albany, v. 12, p. 29-40,1997.

RIBEIRO, C. Metacognição: um apoio ao processo de aprendizagem. Psicologia: Reflexão e Crítica. Porto Alegre, v.16, p.109-116, 2003.

RIESGO R.; ROHDE, L.A. A neurobiologia do TDAH. In: KAPCZINSKI, F.; QUEVEDO, J.L.; IZQUIERDO, I. (Eds.). Bases Neuroquímicas dos Transtornos Psiquiátricos. Ed.2. Porto Alegre: Artes Médicas, p 338-40, 2004.

ROHDE, L.A.; HALPERN, R. Transtorno de déficit de atenção/hiperatividade: atualização. Jornal de Pediatria. Porto Alegre, v.80, n.2, p.61-70, 2004.

ROHDE, L.A.; BARBOSA, G.; TRAMONTINA, S.; POLANCZIK, G. Transtorno do déficit de atenção/hiperatividade: atualização diagnóstica e terapêutica. Revista Brasileira de Psiquiatria. São Paulo, v.22, p.7-11, 2000a. 
ROHDE, L.A.; BIEDERMAN, J; ZIMMERMANN, H; SCHMITZ, M; MARTINS, S; TRAMONTINA, S. Exploring age-of-onset criterion in Brazilian adolescents. European Child Adolesc Psychiatry. V. 9, p. 212-218, 2000b.

ROHDE, L.A.; BIEDERMAN, J.; KNIJIK, M.P.; KETZER, C.; CHACHAMOVICH, E.; VIEIRA, G.M.; PINZON, V. Explorind different information sources for DSM-IV ADHD diagnoses in brazilian adolescents. Journal of Attention Disorders. Salt Lake City, v.3, p.91-96, 1999.

ROHDE, L.A., BIEDERMAN, J., BUSNELLO, E.A., ZIMMERMANN, H; SCHMITZ M; MARTINS S; TRAMONTINA S.ADHD in a school sample of Brazilian adolescents: a study of prevalence, comorbid conditions, and impairments. Journal of the American Academy of Child and Adolescent Psychiatry. Chicago, v.38, p.716-722 1999b.

ROHDE, L.A.; BUSNELLO, E.D.; PINZON, V.; CHACHAMOVICH, E.; VIEIRA, E. Transtorno de déficit de atenção/hiperatividade: revisando conhecimentos. Revista Brasileira de Psiquiatria. São Paulo, v.20, p.166-178, 1998.

ROMERO-AYUSO, D.M.; MAESTU, F.; GONZALEZ-MARQUES, J.; ROMOBARRIENTOS, C.; ANDRADE, J.M. Executive dysfunction in attention deficit hyperactivity disorder in childhood. Revista de Neurología. Barcelona , v.42, p.265271, 2006.

ROSENTHAL E.N.;.RICCIO, C.A.; GSANGER, K.M.; JARRATT K.P. Digit Span components as predictors of attention problems and executive functioning in children. Archives of Clinical Neuropsychology. Albany, v.21, p.131-139, 2006.

RUCKLIDGE J.J.; TANNOCK, R. Psychiatric, psychosocial, and cognitive functioning of female adolescents with ADHD. Journal of the American Academy of Child and Adolescent Psychiatry. Chicago, v.40, p.530-540, 2001.

RUSSELL, V.A.; SAGVOLDEN, T.; JOHANSEN, E.B. Animal models of attention-deficit hyperactivity disorder. Behavioral and Brain Functions. Oslo, v.1, p.9-26, 2005.

SAGVOLDEN, T.; AASE, H.; ZEINER, P.; BERGER, D. Altered reinforcement mechanisms in attention-deficit/hyperactivity disorder. Behavioral and Brain Function. Oslo, v.94, p.61-71, 1998.

SANTOS, F.H. Funções Executivas. In: ANDRADE, V.M.; SANTOS, F.H. dos; AMODEO, O.F.B. (Orgs.). Neuropsicologia Hoje. Ed.1. São Paulo: Artes Médicas, 2004. 474p.

SCAHILL, L.; SCHWAB-STONE, M.; MERIKANGAS, K.; LECKMAN, J.F.; ZHANG, H; KASL, S. Psychosocial and clinical correlates of ADHD in a community sample of school-age children. Journal of the American Academy of Child and Adolescent Psychiatry. Chicago, n.38, p.976-984, 1999. 
SCHMITZ, M.; CADORE, L.; PACZKO, M.; KIPPER, L.; CHAVES, M.; ROHDE, L.A.; MOURA, C.; KNIJNIK, M. Neuropsychological performance in DSM-IV ADHD subtypes: an exploratory study with untreated adolescents. Canadian Journal of Psychiatry, Ottawa, v.47, p.863-869, 2002.

SEIDMAN, L.J.; BIEDERMAN, J.; VALERA, E.; MONUTEAUX, M.C.; DOYLE, A.E.; FARAONE, S.V. Neuropsychological functioning in girls with attentiondeficit/hyperactivity disorder with and without learning disabilities. Neuropsychology.. Cleveland, v.20, p.166-167, 2006.

SEIDMAN, L.J.; BIEDERMAN, J.; MONUTEAUX, M.C.; VALERA, E.; DOYLE, A.E.; FARAONE, S.V. Impact of gender and age on executive functioning: do girls and boys with and without attention deficit hyperactivity disorder differ neuropsychologically in preteen and teenage years? Developmental Neuropsychology. Lousville, v.27, p.79105, 2005.

SEIDMAN, L.J.; BIEDERMAN, J.; MONUTEAUX, M.C.; DOYLE, A.E.; FARAONE, S.V. Learning disabilities and executive dysfunction in boys with attention-deficit/hyperactivity disorder. Neuropsychology. Cleveland, v.15, p.544-556, 2001.

SEIDMAN, L.J.; BIEDERMAN, J.; FARAONE, S.V.; WEBER, W.; OUELLETTE, C. Toward defining a neuropsychology of attention deficit-hyperactivity disorder: performance of children and adolescents from a large clinically referred sample. $\mathbf{J}$ Consult Clin Psychol., V.65, P.150-60, 1997.

SERGEANT, J.A.; GEURTS, H.; HUIJBREGTS, S.; SCHERES, A.; OOSTERLLAN, J. The top and the bottom of ADHD: A neuropsychological perspective. Neuroscience \& Biobehavioral Reviews. St. Andrews, v.27, p.583-592, 2003.

SHALLICE, P. W.; BURGESS, P. W. Deficits in strategy application following frontal lobe damage in man. Brain, v. 114,p. 727-741, 1991.

SHALLICE, T. From neuropsychology to mental structure. Cambridge: Cambridge University Press, 1988. 461p.

SHEPPARD, D.M.; BRADSHAW, J.L.; MATTINGLEY, J.B.;LEE, P. Effects of stimulant medication on the lateralization of line bisection judgements of children with attention deficit hyperactivity disorder. Journal of Neurology, Neurosurgery and Psychiatry. London, v.66, p.57-63, 1999.

SLOMINE, B.S.; SALORIO, C.F.; GRADOS, M.A.; VASA, R.A.; CHRISTENSEN, J.R.; GERRING, J.P. Differences in attention, executive functioning, and memory in children 
with and without ADHD after severe traumatic brain injury. Journal of International Neuropsychological Society. Albuquerque, v.11, p.645-653, 2005.

SOMMER, T.; ROSE, M.; GLASCHER, J.; WOLBERS, T.; BUCHEL, C. Dissociable contributions within the medial temporal lobe to encoding of object-location associations. Learning and Memory. Houston, v.12, p.343-51, 2005.

SONUGA-BARKE, E. J. S. Annotation: On dysfunction and function in psychological theories of childhood disorder. Journal of Child Psychology and Psychiatry. London, v.35, p.801-815, 1994.

SONUGA-BARKE, E. J. S.; TAYLOR, E.; SEMBI, S.; SMITH, J. Hyperactivity and delay aversion-I. The effect of delay on choice. Journal of Child Psychology and Psychiatry. London, v. 33, p.387-398, 1992.

SOUZA, I. G. S. ; PINHEIRO, M. A. ; MATTOS, P. ; FRANCO, V. A. . Comorbidade em Crianças e Adolescentes com transtorno do Déficit de Atenção. São Paulo, Arquivos de Neuro-Psiquiatria, v. 2, p. 401-406, 2001.

SPELKE, E.; HIRST, W.; NEISSER, U. Skills of divided attention. Cognition. York, v.4, p.215-230, 1976.

SPRICH, S.; BIEDERMAN, J.; CRAWFORD, M.H.; MUNCY, E.; FARAONE S,V. Adoptive and biological families of children and adolescents with ADHD. Journal of American Academy of Child and Adolescent Psychiatry. Chicago, v. 39, p. 14321437, 2000.

STERNBERG, R.J. Atenção e consciência. In: STERNBERG, R.J. Psicologia cognitiva. Porto Alegre: Artmed, p.77-108, 2000.

STEVENS, J.; QUITTNER, J.B.; ZUCKERMAN, J.B.; MOORE, S. Behavioral inhibition, self-regulation of motivation, and working memory in children with attention deficit hyperactivity disorder. Developmental Neuropsychology. Lousville, v.21, p.117-139, 2002.

STILL, G.F. Some abnormal psychical conditions in childhood. Lancet. London, v.1, 1008, 1902.

STUSS, D.T.; ALEXANDER. Executive function and the frontal lobe: a conceptual view. Psychological Research. Berlin, v.63, p.389-298, 2000.

SUZUKI, M.; TSUKIURA, T.; MATSUE, Y.; YAMADORI, A.; FUJII T. Dissociable brain activations during the retrieval of different kinds of spatial context memory. Neuroimage. London, v.25, p.993-1001, 2005. 
TEICHER M.H.; ITO, Y.; GLOD C.A. Objective measurement ao hiperactivity and attentional problems in ADHD. Journal of the American Academy of Child and Adolescent Psychiatry. Chicago, v.35, p.334-42, 1996.

THAPAR A, HOLMES J, POULTON K, HARRINGTON R. Genetic basis of attention deficit and hyperactivity. The British Journal of Psychiatry. Stanford, v.174, p.105111, 1999.

TOPLAK, M.E.; RUCKLIDGE, J.J.; HETHERINGTON, R.; JOHN, S.C.; TANNOCK, R. Time perception deficits in attention-deficit/ hyperactivity disorder and comorbid reading difficulties in child and adolescent samples. Journal of Child Psychology and Psychiatry. London v.44, p.888-903, 2003.

VALERA, E.M.; FARAONE, S.V.; BIEDERMAN, J.; POLDRACK, R.A.; SEIDMAN LJ. Functional neuroanatomy of working memory in adults with attention-deficit/hyperactivity disorder. Biological Psychiatry. West Haven, v.57, p.439-447, 2005.

van der MEERE, J. The role of attention. In: SANDBERG, S. (Ed.). Hyperactivity disorders of childhood. Cambridge: Cambridge University Press, pp162-213, 1996.

van der MEERE, J.; SHALEV, R.; BÖRGER, N.; \& GROSS-TSUR, V. Sustained attention, activation and MPH in ADHD: A research note. Journal of Child Psychology and Psychiatry. London, v.36, p.697-703, 1995.

van der MEERE, J.; WEKKING, E.E.; SERGEANT J. Sustained attention and pervasive hyperactivity. Journal of Child Psychology and Psychiatry and Allied Disciplines, London, v.2, p.275-284, 1991.

VASCONCELOS, M.M.; WERNER JR, J; MALHEIROS, A.F.A.; LIMA, D.F.N.; SANTOS, I.S.O.; BARBOSA, J.B. Prevalência do transtorno do déficit de atenção/hiperatividade numa escola pública primária. Arquivos de Neuropsiquiatria. São Paulo, v.61, p. 6773, 2003.

WAGNER, K.; FRINGS, L.; QUISKE, A.; UNTERRAINER, J.; SCHWARZWALD, R.; SPREER, J.; HALSBAND, U.; SCHULZE-BONHAGE, A. The reliability of fMRI activations in the medial temporal lobes in a verbal episodic memory task. Neuroimage. London, v.28, p.122-131, 2005.

WESCHLER, D.. FIGUEREDO, V.L.M. (padr. brasileira) WISC-III: escala de inteligência Wechsler para crianças - adaptação brasileira da $3^{a}$ edição. São Paulo: Casa do Psicólogo, 2002. 322p.

WELSH, M. C.; PENNINGTON, B. F. Assessing frontal lobe functioning in children: views from developmental psychology. Developmental Neuropsychology. Lousville, v.4, p.199-230, 1988. 
WESTERBERG, H.; HIRVIKOSKI, T.; FORSSBERG, H.; KLINGBERG, T. Brief reportvisuo-spatial working memory span: a sensitive measure of cognitive deficits in children with ADHD. Child Neuropsychology. Grand Rapids, v. 10, p. 155-161, 2004.

WILLIAMS, B.R.; PONESSE, J.S.; SCHCHAR, R.J.; LOGAN, G.D.; TANNOCK, R. Development of inhibitoy control across the life span. Developmental Psychology. Lousville, v.35, p.205-213, 1999.

WOLRAICH M.L.; HANNA, J.N.; PINNOCKY, T.Y. et al. Comparision of diagnostic criteria for Attention-Deficit Hiperactivity Disorder in a County-wide Sample. Journal of the American Academy of Child and Adolescent Psychiatry. Chicago, v.35, p.319324, 1996 . 


\section{APÊNDICE A - Termo de Consentimento TERMO DE CONSENTIMENTO LIVRE E ESCLARECIDO \\ Transtorno do Déficit de Atenção e Hiperatividade: \\ Alterações de Memória nos Diferentes Subtipos}

$\mathrm{Eu}$,

fui procurado(a) pelo José Neander Silva Abreu, professor da Faculdade Ruy Barbosa e doutorando em Neurociências e Comportamento pela Universidade de São Paulo, psicólogo com o registro 03/01809 no Conselho Regional de Psicologia Bahia/Sergipe, acerca do projeto com o título supracitado desenvolvido por este pesquisador que está avaliando adolescentes (de 11 a 14 anos) que são portadores do Transtorno do Déficit de Atenção e Hiperatividade. Esses adolescentes realizarão testes neuropsicológicos, de desenvolvimento neuropsicomotor e de inteligência exclusivamente, não acarretando quaisquer riscos para sua saúde. Não há qualquer tipo de procedimento invasivo (tais como coleta de sangue, radiação etc.). Os resultados destes testes precisam ser comparados com o de adolescentes sem o transtorno. Neste sentido, sendo o meu filho selecionado para o referido estudo, autorizo a realização dos exames neuropsicológicos $\quad$ e de inteligência no(a) menor

de anos de idade, sob a minha inteira responsabilidade, a participar desta pesquisa. Conforme fui informado, os testes serão aplicados em 2 sessões 1:10 cada uma e 20 minutos, se necessário complementação em uma $3^{\mathrm{a}}$ sessão de 25 minutos. Os testes serão aplicados em sala silenciosa de atendimento individual na própria escola. Todas as informações por mim fornecidas ou coletadas de meu (minha) filho(a) serão mantidas em sigilo absoluto.

Salvador, de de 2006/2007.

Assinatura do Responsável:

Telefone: Celular: 


\section{APÊNDICE B -}

Questionário a ser preenchido pelos pais

ou representante legal

Número de Identificação

(favor não preencher)

Caros Pais ou responsável legal,

Por favor preencha este questionário escrevendo a resposta direta ou marcando um $\mathbf{X}$ no local apropriado.

\section{IDENTIFICAÇÃO}

Nome do(a) Adoloscente ou Pré-Adolescente

Sexo $\quad$ Masculino $\square \quad$ Feminino $\square$

\begin{tabular}{|l|c|c|c|}
\hline & Ano & Mês & Dia \\
\hline Data de Preenchimento do Questionário & & & \\
\hline Data de Nascimento do Adolescente & & & \\
\hline Idade (favor não preencher) & & & \\
\hline
\end{tabular}

2. Identificação dos Pais

Nome do Pai:

Data de Nascimento:

Profissão:

Nome da Mãe:

Data de Nascimento: ___ _ _

Profissão:

Escolaridade do Pai

Analfabeto/Primário incompleto

Primário Completo/Ginasial $\left(1^{\circ} \mathrm{grau}\right)$ Incompleto

Ginasial Completo/Colegial( $\left.2^{\circ} \mathrm{grau}\right)$ Incompleto

Colegial $\left(2^{\circ}\right.$ grau Completo)/Superior Incompleto

Superior Completo

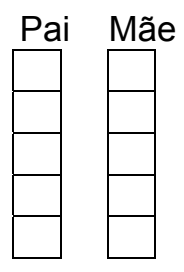

Renda Familiar

Menos de 5 salários mínimos

De 5 a 10 salários mínimos

De 11 a 20 salários mínimos

Mais de 20 salários mínimos

Por favor informe, assinalando nas caselas, quantos destes itens tem em sua casa:

İTENS

Televisão em cores

Rádio

Banheiro

Automóvel

Empregada mensalista

Aspirador de pó

Máquina de lavar

$\begin{array}{ccc}\mathbf{0} & \mathbf{1} & \mathbf{2} \\ \square & \square & \\ \square & \square & \\ \square & \square & \square \\ \square & \square & \square \\ \square & \square & \\ \square & \square & \\ \square & \square & \end{array}$


Videocassete e/ou DVD

Geladeira

Freezer (independente ou parte de geladeira duplex)

\section{SAÚDE}

1. Já apresentou alguma doença que tenha atingido o cérebro

Outra: Especificar:

Meningite/Encefalite

2. Apresenta ou apresentou nos últimos 6 meses

Problemas de baixa auto-estima Comparação freqüente com colegas

'Tristeza profunda

Dificuldade de relacionamento social

Irritabilidade

Agressividade

Instabilidade (choro/riso)

\section{VIDA ESCOLAR}

Seu/sua filho (a)

1. Cursa que série?

2. Já repetiu de ano? Qual série?

3. Ele tem dificuldades escolares com história de recuperação

4. Se sim, em que disciplinas

$$
\begin{array}{r}
\text { Português/Redação } \\
\text { Matemática } \\
\text { Ciências } \\
\text { Histpória/Geografia } \\
\text { Inglês }
\end{array}
$$

Artes/Desenho

5.Apresenta problemas na leitura? Se não, pule para o item 8 .

6. Estes problemas têm interferido significativamente no rendimento escolar?

7. Apresenta troca de letras na leitura, ou de palavras inteiras com freqüência prejudicando-o no curso normal da leitura?

8. Apresenta problemas com matemática? Se não, pule para o item 11.

9. Estes problemas têm interferido com o rendimento escolar?

10. Neste caso você considera que há mais dificuldade para

Transformar problemas escritos em linguagem matemática

Reconhecer símbolos matemáticos (ex.:,,$+- \neq,<$,etc)

Copiar corretamente números

Contar objetos

Seguir seqüência numa operação matemática

11. Apresenta problemas na escrita?

12. Estes problemas têm interferido com o rendimento escolar?

13. Neste caso você considera que há mais dificuldade com

Dificuldade para compor um texto escrito

Erros freqüentes de gramática e pontuação na frase

Muitos erros relativos a como escrever uma palavra (troca de letras, etc.)

Caligrafia excessivamente ruim 


\section{APÊNDICE C - Folha de Registro - Piloto}

\section{Estudo Piloto - Teste MEMO}

Nomeie as figuras que aparecem segundo a ordem. Nome:

Idade:

Série:

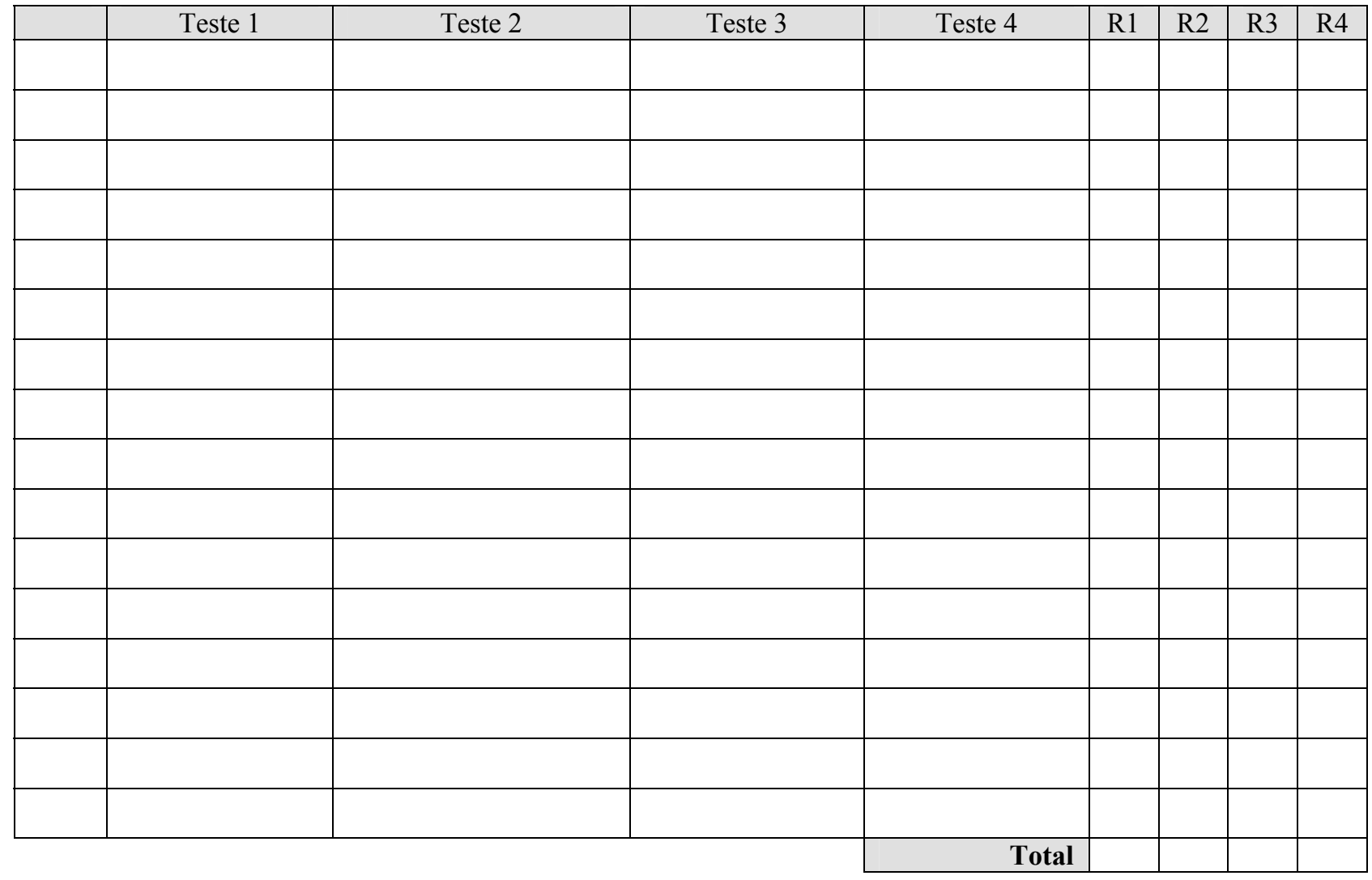




\section{APÊNDICE D - Folha de Registro MEMO}

\section{PROTOCOLO DE AVALIAÇÃO DO TESTE DE MEMÓRIA MEMO}

Nome:

Idade: a e m Série:

Data: 1

Escola: Examinador:

\begin{tabular}{|c|c|c|c|c|c|}
\hline \multicolumn{6}{|c|}{ TESTE MEMO I - RESULTADOS - CATEGORIZÁVEIS } \\
\hline Tentativa I & Tentativa II & Tentativa III & $\begin{array}{c}\text { Memória } \\
\text { Longo Prazo }\end{array}$ & Agrupado & MLP-Agrupado \\
\hline & & & & & \\
\hline & & & & & \\
\hline & & & & & \\
\hline & & & & & \\
\hline & & & & & \\
\hline & & & & & \\
\hline & & & & & \\
\hline & & & & & \\
\hline & & & & & \\
\hline & & & & & \\
\hline & & & & & \\
\hline & & & & & \\
\hline & & & & & \\
\hline & & & & & \\
\hline & & & & & \\
\hline & & & Totais & & \\
\hline & & & & & \\
\hline
\end{tabular}

\section{CONSIGNA - TDAH I - Figuras Categorizáveis}

Tentativa I: Vamos fazer um jogo. Você verá sendo apresentada na tela do computador figuras que aparecerão por 5 segundos. Tente lembrar dessas figuras pois ao final de cada apresentação eu pedirei que você possa me dizer as que puder lembrar. Não importa a ordem que você lembre.

Tentativas II e III: Vamos continuar o jogo. Novamente você verá as figuras. Tente lembrar de quantas puder, em qualquer ordem. Diga também aquelas que você já falou na primeira vez que the apresentei. Memória de Longo Prazo: Agora quero que você diga para mim as figuras que puder lembrar daquelas que lhe mostrei. Diga quantas puder, em qualquer ordem.

Agrupado: Agora você verá outras figuras. Olhe atentamente pois depois terá que me dizer quais as figuras que viu.

Memória de Longo Prazo- Agrupado: Agora quero que você diga para mim as figuras que puder lembrar daquelas que Ihe mostrei. Diga quantas puder, em qualquer ordem. 


\section{PROTOCOLO DE AVALIAÇÃO DO TESTE DE MEMÓRIA MEMO}

Nome:

Idade:

a e

m Série:

Data:

l_

Escola:

Examinador:

\begin{tabular}{|c|c|c|c|c|c|}
\hline CATEGORI & VEIS & TESTE MEM & I - RESULT & DS - NÃO & \\
\hline Tentativa I & Tentativa II & Tentativa III & $\begin{array}{c}\text { Memória } \\
\text { Longo Prazo }\end{array}$ & Agrupado & MLP-Agrupado \\
\hline & & & & & \\
\hline & & & & & \\
\hline & & & & & \\
\hline & & & & & \\
\hline & & & & & \\
\hline & & & & & \\
\hline & & & & & \\
\hline & & & & & \\
\hline & & & & & \\
\hline & & & & & \\
\hline & & & & & \\
\hline & & & & & \\
\hline & & & & & \\
\hline & & & & & \\
\hline & & & & & \\
\hline & & & Totais & & \\
\hline & & & & & \\
\hline
\end{tabular}

\section{CONSIGNA - TDAH II - Figuras Não Categorizáveis}

Tentativa I: Vamos fazer um jogo. Você verá sendo apresentada na tela do computador figuras que aparecerão por 1 MINUTO. Tente lembrar dessas figuras pois ao final eu pedirei que você possa me dizer as que puder lembrar. Não importa a ordem que você lembre.

Tentativas II e III: Vamos continuar o jogo. Novamente você verá as figuras. Tente lembrar de quantas puder, em qualquer ordem. Diga também aquelas que você já falou na primeira vez que lhe apresentei.

Memória de Longo Prazo: Agora quero que você diga para mim as figuras que puder lembrar daquelas que the mostrei. Diga quantas puder, em qualquer ordem.

Agrupado: Agora você verá outras figuras. Olhe atentamente pois depois terá que me dizer quais as figuras que viu.

Memória de Longo Prazo- Agrupado: Agora quero que você diga para mim as figuras que puder lembrar daquelas que Ihe mostrei. Diga quantas puder, em qualquer ordem. 
ANEXO A - Aprovação do Comitê de Ética - USP

Aprovação

Of. 1406/CEPH-04/07/06 
